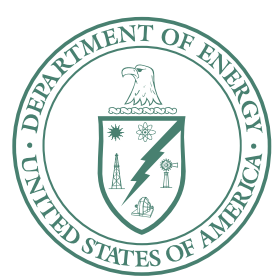

U.S. Department of Energy

Idaho Operations Office

\title{
Engineering Evaluation/Cost Analysis for Power Burst Facility (PER-620) Final End State and PBF Vessel Disposal
}

May 2007 


\section{Engineering Evaluation/Cost Analysis for Power Burst Facility (PER-620) Final End State and PBF Vessel Disposal}

May 2007 


\section{ABSTRACT}

Preparation of this engineering evaluation/cost analysis is consistent with the joint U.S. Department of Energy and U.S. Environmental Protection Agency Policy on Decommissioning of Department of Energy Facilities Under the Comprehensive Environmental Response, Compensation, and Liability Act, (DOE and EPA 1995) which establishes the Comprehensive Environmental Response, Compensation, and Liability Act non-time-critical removal action process as an approach for decommissioning. This removal action is consistent with the remedial action objectives of the Record of Decision, Power Burst Facility and Auxiliary Reactor Area; Operable Unit 5-12 (DOE-ID 2000). The removal action will place the facility in a final configuration that remains protective of human health and the environment.

The scope of this engineering evaluation/cost analysis is to evaluate alternatives and recommend a preferred alternative for the final end state of the $\mathrm{PBF}$ and the final disposal location for the PBF vessel.

The recommended removal action includes removing and disposing of the PBF vessel at the Idaho CERCLA Disposal Facility and demolishing the reactor building to below ground level. This is Alternative 3 of the three alternatives considered in this evaluation. 


\section{EXECUTIVE SUMMARY}

This engineering evaluation/cost analysis (EE/CA) was prepared to support a determination for the Power Burst Facility (PBF) final end state and the disposal location for the PBF vessel. The process to accomplish this determination is to perform a non-time-critical removal action (NTCRA). The approach satisfies environmental review requirements and provides for stakeholder involvement while supplying a framework for selecting the decommissioning alternative. The approach also establishes an Administrative Record for documentation of the removal action.

In keeping with the joint U.S. Department of Energy (DOE) and U.S. Environmental Protection Agency (EPA) Policy on Decommissioning of Department of Energy Facilities Under the Comprehensive Environmental Response, Compensation, and Liability Act (DOE and EPA 1995), this EE/CA was developed in accordance with the Comprehensive Environmental Response, Compensation, and Liability Act (CERCLA) as amended by Public Law 99-499, Superfund Amendments and Reauthorization Act of 1986, and in accordance with the "National Oil and Hazardous Substances Pollution Contingency Plan" (40 Code of Federal Regulation [CFR] 300)." The removal action objectives of this NTCRA are also consistent with the Record of Decision, Power Burst Facility and Auxiliary Reactor Area; Operable Unit 5-12 (DOE-ID 2000) and supports the overall remediation goals established through the Federal Facility Agreement and Consent Order and the DOE goal of reducing the "risk footprint" by consolidating wastes in the Idaho CERCLA Disposal Facility (ICDF) and reducing surveillance and maintenance costs on legacy buildings and structures.

PBF was designed and built to perform experiments on nuclear fuels. Samples were exposed to transient and steady-state neutron fluxes to test fuel behavior under controlled accident conditions. PBF was put in standby condition in 1985, and nuclear fuels that powered the vessel were removed in 2003 and put in dry storage at the Idaho Nuclear Technologies and Engineering Complex. Decommissioning activities began in February 2005 with approval of the Action Memorandum for Phase 1 of the Decommissioning for the Power Burst Facility Reactor Building (PER-620) (DOE/NE-ID 2005). Phase 1 of PBF decommissioning resulted in PBF being put into a "cold, dark, and dry" configuration. Activities preparatory to the final end state and vessel disposal determination began again at PBF in October 2006 under the Action Memorandum for General Decommissioning Activities Under the Idaho Cleanup Project (DOE/ID 2006).

The scope of this EE/CA is to evaluate alternatives and recommend a preferred alternative for the final end state of the PBF and the final disposal location for the PBF vessel.

Three alternatives are under consideration for the PBF NTCRA:

- $\quad$ Alternative 1, the no-action alternative, is included for completeness and comparative purposes. However, the alternative only defers taking further action at the PBF to a future date and does not address the potential for adverse threat to human health and the potential threat of release of hazardous substances to the environment. It is not recommended for these reasons.

- $\quad$ Alternative 2 grouts the PBF vessel in place. This alternative provides the most protection for the worker; however, it requires ongoing land use restrictions because wastes would be left in place above and immediately below ground level and does not meet the DOE goal of reducing the "risk footprint" by consolidating wastes and reducing surveillance and maintenance costs on legacy buildings and structures. 
- Alternative 3 removes the PBF vessel, removes the radioactive source to be protective of human health, and demolishes the reactor building to below ground level. The PBF vessel would be disposed of at the ICDF, an on-Site disposal facility. This alternative meets the remedial action objectives established in the Operable Unit 5-12 Record of Decision (DOE-ID 2000). Alternative 3 is the recommended alternative because it provides the most protection for the public health and the environment and supports DOE's goal of risk footprint reduction and waste consolidation.

Residual radioactive materials remaining at PBF after decommissioning activities are completed would stay in place and would be managed under the Sitewide Institutional Control Program. Reactor building void spaces would be backfilled as practicable. Backfill would consist of grout, as necessary; inert demolition waste from the above ground level structures; and clean backfill materials.

This EE/CA will become part of the Idaho National Laboratory (INL) Administrative Record. Documentation supporting this EE/CA, such as the Engineering Design Files, will also be included in the Administrative Record. The INL Administrative Record is on the Internet at http://ar.inel.gov/ and is available to the public at the following locations:

$\begin{array}{ll}\text { Albertsons Library } & \text { INL Technical Library } \\ \text { Boise State University } & \text { DOE Public Reading Room } \\ 1910 \text { University Drive } & \text { 1776 Science Center Drive } \\ \text { Boise, ID } 83725 & \text { Idaho Falls, ID } 83415 \\ \text { (208) } 426-1625 & \text { (208) } 526-1185\end{array}$




\section{CONTENTS}

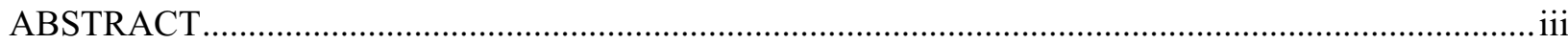

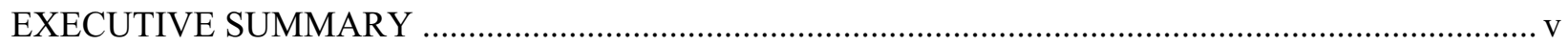

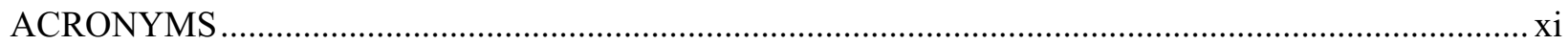

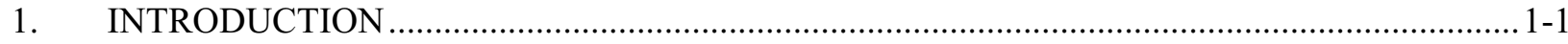

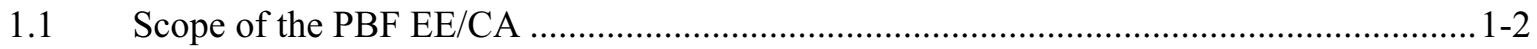

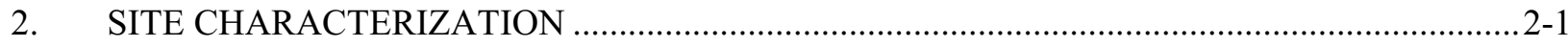

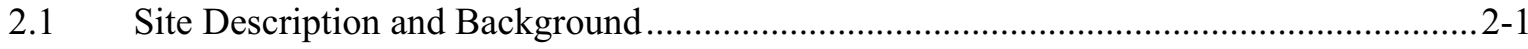

2.1.1 Idaho National Laboratory Site and Idaho Cleanup Project............................2-1

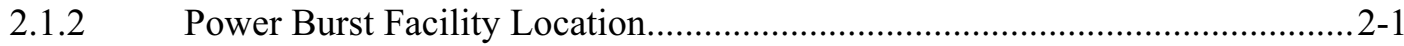

2.1.3 Power Burst Facility Description ..............................................................2-2

2.2 Previous Closure/Cleanup Activities at PBF .................................................................

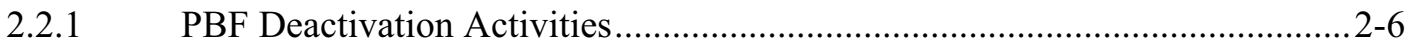

2.2.2 Voluntary Consent Order Activities............................................................... 2-6

2.2.3 Comprehensive Environmental Response, Compensation, and Liability Act Activities at the PBF ........................................................... 2-6

2.2.4 Decommissioning Preparatory Activities................................................... 2-7

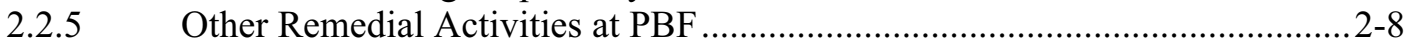

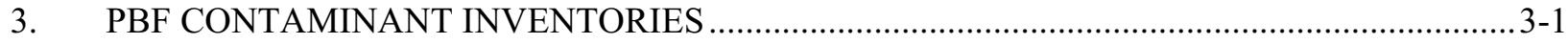

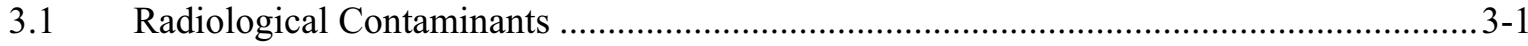

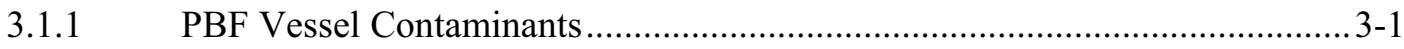

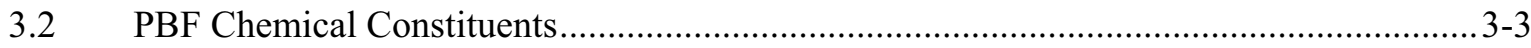

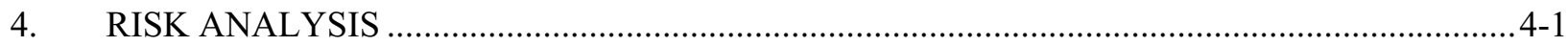

4.1 Human Health Risk Analysis ................................................................................ $4-1$

4.1.1 Human Health Risk Analysis for Radionuclides.......................................... 4-1

4.1.2 Chemical Constituent Risk Analysis............................................................ 4-3

4.2 Groundwater Risk Analysis ................................................................................ $4-5$

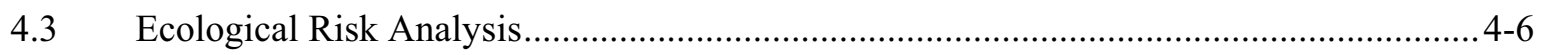

5. IDENTIFICATION OF REMOVAL OBJECTIVES …..........................................................

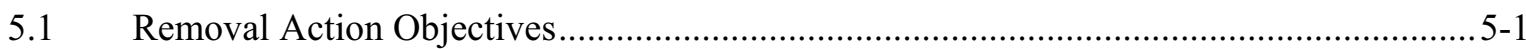


6. IDENTIFICATION OF REMOVAL ACTION ALTERNATIVES FOR PBF

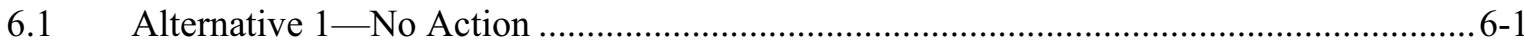

6.2 Alternative 2 - Grouting PBF Vessel in Place ............................................................. 6-1

6.3 Alternative 3-Removal and Disposal of PBF Vessel at the ICDF .............................. 6-2

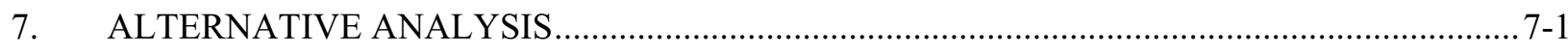

7.1 Effectiveness of the Alternatives ................................................................................. $7-1$

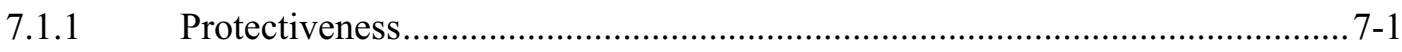

7.2 Implementability of the Alternatives ................................................................... $7-2$

7.2.1 Technical and Administrative Feasibility ..................................................... 7-2

7.2.2 Availability of Equipment, Personnel, and Services .....................................

Cost of the Alternatives ............................................................................................

7.4 Summary of Alternative Evaluation ......................................................................... $7-4$

8. RECOMMENDED REMOVAL ACTION ALTERNATIVE …............................................ 8-1

8.1 Compliance with Environmental Regulations ......................................................... 8-3

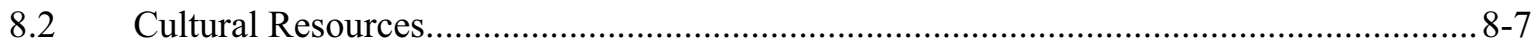

8.3 Compliance with Disposal Facility Waste Acceptance Criteria .................................... 8-8

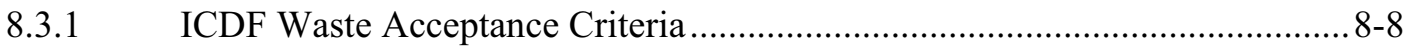

8.3.2 Achieving Removal Action Objectives....................................................... 8-8

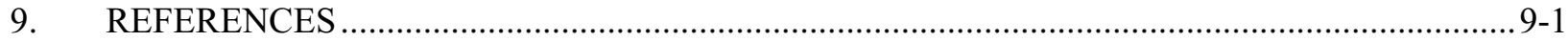

Appendix A-Total Above and Below Ground Level Radionuclides and Activity Value ..................... A-1

Appendix B $-0 \mathrm{ft}$ to $10 \mathrm{ft}$ Below Ground Level Radionuclides and Activity Value ............................. B-1

Appendix C-Above Ground Level Radionuclides and Activity ..................................................... C-1

Appendix D—PBF Vessel Radionuclides and Activity by Component ............................................. D-1 


\section{FIGURES}

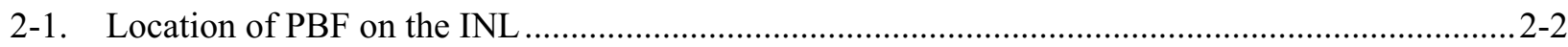

2-2. Photo of the Power Burst Facility (Power Excursion Reactor [PER]-620) .................................2-3

2-3. Cutaway rendering of the PBF (PER-620) looking east.............................................................2-4

2-4. Power Burst Facility Vessel Installation 1970........................................................................2-5

2-5. Cutaway rendering of the PBF vessel (in-pile tube dispositioned to ICDF) .............................2-5

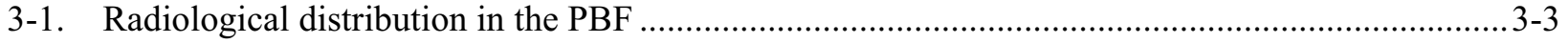

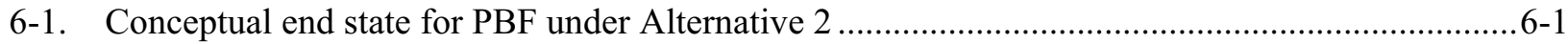

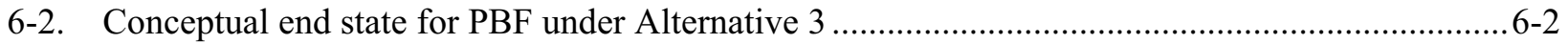

8-1. Conceptual end state under Alternative 3 for the PBF ............................................................. 8-2

\section{TABLES}

3-1. Total radiological source term by location in PBF .................................................................... 3-2

3-2. Estimated inventory of chemical constituents in the below-ground levels of the PBF .................3-4

4-1. Radionuclide soil concentrations compared to soil screening levels (2005 inventories) ..............4-2

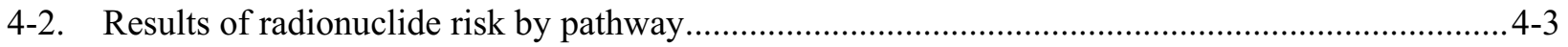

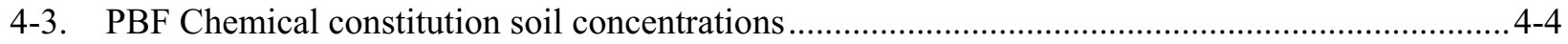

4-4. Results of screening nonradiological contaminants ...............................................................

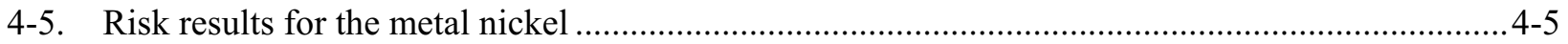

7-1. Cost estimates for the viable removal action alternatives in 2007 dollars................................. $7-4$

8-1. Summary of applicable or relevant and appropriate requirements for the Power Burst Facility non-time-critical removal action 


\section{ACRONYMS}

ARAR applicable or relevant and appropriate requirement

CERCLA Comprehensive Environmental Response, Compensation, and Liability Act

CFR Code of Federal Regulations

$\mathrm{Ci} \quad$ Curies

CRMP Cultural Resources Management Plan

D\&D decommissioning and demolition

DEQ Idaho Department of Environmental Quality

DOE Department of Energy

DOE-ID Department of Energy Idaho Operations Office

EDF Engineering Design File

$\mathrm{EE} / \mathrm{CA} \quad$ engineering evaluation/cost analysis

EPA Environmental Protection Agency

ETR Engineering Test Reactor

FFA/CO Federal Facility Agreement and Consent Order

HI Hazard Index

HWMA Hazardous Waste Management Act

ICDF Idaho CERCLA Disposal Facility

ICP Idaho Cleanup Project

INL Idaho National Laboratory (formerly INEEL)

MCL Maximum Concentration Limit

NCRP National Council on Radiation Protection

NHPA National Historic Preservation Act

NTCRA non-time-critical removal action

OU operable unit

PBF Power Burst Facility

PCB polychlorinated biphenyl

PER Power Excursion Reactor

RAO remedial action objective

RCRA Resource Conservation and Recovery Act

ROD Record of Decision 
SSL soil screening level

TSCA Toxic Substances Control Act

USC United States Code

VCO Voluntary Consent Order

WAC Waste Acceptance Criteria 


\section{Engineering Evaluation/Cost Analysis for Power Burst Facility (PER-620) Final End State and PBF Vessel Disposal}

\section{INTRODUCTION}

The engineering evaluation/cost analysis (EE/CA) process is used to determine the end state of the Power Burst Facility (PBF) and final disposal site for the PBF vessel. The EE/CA is intended to satisfy environmental review requirements while providing a framework for selecting the end states and satisfying Administrative Record requirements for documentation of the removal action. This EE/CA identifies removal action proposed alternatives and analyzes these alternatives for effectiveness, implementability, and cost. This EE/CA also evaluates the proposed alternatives for meeting the U.S. Department of Energy (DOE) goal of reducing the "risk footprint" by consolidating wastes and reducing surveillance and maintenance costs on legacy buildings and structures. Following the issuance of this EE/CA for public comment and consideration of comments received during the public review period, DOE will issue, with concurrence from the Idaho Department of Environmental Quality (DEQ) and U.S. Environmental Protection Agency (EPA), an Action Memorandum documenting the selected alternative. The Action Memorandum will be placed in the Administrative Record.

This EE/CA was developed in accordance with the Comprehensive Environmental Response, Compensation, and Liability Act (CERCLA) (42 United States Code [USC] § 9601 et seq.) as amended by the "Superfund Amendments and Reauthorization Act of 1986" (Public Law 99-499) and in accordance with the "National Oil and Hazardous Substances Pollution Contingency Plan" (40 CFR 300). The removal action objectives of this NTCRA are also consistent with the Record of Decision, Power Burst Facility and Auxiliary Reactor Area; Operable Unit 5-12 (DOE-ID 1991) that provides the basis for cleanup levels at PBF and supports the overall remediation goals established through the Federal Facility Agreement and Consent Order and the DOE goal of reducing the "risk footprint" by consolidating wastes in the Idaho CERCLA Disposal Facility (ICDF), and reducing surveillance and maintenance costs on legacy buildings and structures.

The non-time-critical removal action (NTCRA) for PBF is consistent with the Record of Decision, Power Burst Facility and Auxiliary Reactor Area; Operable Unit 5-12, (DOE-ID 2000) and supports the overall remediation goals established through the Federal Facility Agreement and Consent Order for the Idaho National Engineering Laboratory (FFA/CO) (DOE-ID 1991) including the remediation goal of returning the Site to an unrestricted status by 2095.

The non-time-critical removal action (NTCRA) for PBF is consistent with the joint DOE and EPA Policy on Decommissioning of Department of Energy Facilities Under the Comprehensive Environmental Response, Compensation and Liability Act (DOE and EPA 1995), which establishes the CERCLA NTCRA process as the preferred approach for decommissioning surplus DOE facilities. Under this policy, a NTCRA may be taken when DOE determines that the action will prevent, minimize, stabilize, or eliminate a risk to human health and/or the environment. When DOE determines that a CERCLA NTCRA is necessary, DOE is authorized to evaluate, select, and implement the removal action that DOE determines is most appropriate to address the potential risk posed by the release or threat of release. This action is taken in accordance with applicable authorities and in conjunction with EPA and the State of Idaho, pursuant to Section 5.3 of the FFA/CO (DOE-ID 1991). 
Performance of this removal action will place the facilities in a configuration that is protective of human health and the environment. Without decommissioning of the PBF, a potential threat of release of hazardous substances exists, and, without action, adverse threats to human health and the environment eventually could occur. As the lead agency, DOE has determined that a removal action is an appropriate means to accomplish the final end state and achieve environmental review requirements. Both the DEQ and the EPA concur that a NTCRA is warranted to place the PBF in a final configuration that is protective of human health and the environment.

\subsection{Scope of the PBF EE/CA}

The scope of this EE/CA is to evaluate alternatives and recommend a preferred alternative for the final end state of the PBF and the final disposal location for the PBF vessel.

Removal activities are currently ongoing at PBF in accordance with the Action Memorandum for General Decommissioning Activities under the Idaho Cleanup Project (DOE-ID 2006). That document allows "decommissioning preparatory activities" to go forth in the "more substantial and significant facilities," such as PBF, but specifically excludes end-state decisions. Therefore, this PBF EE/CA will determine the final end state of the facility and disposition of the PBF vessel while decommissioning preparatory activities are going forward. These decommissioning preparatory activities involve removal of piping and equipment, and routine waste management practices such as removal of lead, polychlorinated biphenyls (PCBs) and asbestos.

Although radiological and nonradiological contamination present in PBF is being removed under the decommissioning preparatory activities, material and contamination estimates used in this EE/CA were generally estimates of what was in PBF prior to starting these activities. These materials and contamination were included in the risk evaluations to ensure a conservative approach was taken for determining risk to human health, groundwater, and the environment for the proposed end-state alternatives evaluated in this EE/CA. 


\section{SITE CHARACTERIZATION}

This section provides summary background information and a description of the Idaho National Laboratory (INL) and PBF. It identifies previous and ongoing closure and cleanup activities and a summary of the radiological and nonradiological characterization of PBF.

\subsection{Site Description and Background}

\subsubsection{Idaho National Laboratory Site and Idaho Cleanup Project}

The INL Site, managed by DOE, is located $51 \mathrm{~km}(32 \mathrm{mi})$ west of Idaho Falls, Idaho. It occupies $2,305 \mathrm{~km}^{2}\left(890 \mathrm{mi}^{2}\right)$ of the northeastern portion of the Eastern Snake River Plain. In 1949, the U.S. Atomic Energy Commission established the INL Site, which was called the National Reactor Testing Station at that time. Its purpose was to conduct nuclear energy research and related activities. It was redesignated the Idaho National Engineering Laboratory in 1974 and then the Idaho National Engineering and Environmental Laboratory in 1997. In 2005, to better focus the laboratory's missions, DOE established the Idaho Cleanup Project (ICP) to bring the environmental management mission to completion and redesignated the Site as the INL Site to better reflect the laboratory's new research directions.

DOE-ID controls all land within the INL Site. Public access is restricted to public highways, sponsored tours, special-use permits, and the Experimental Breeder Reactor I National Historic Landmark. In addition, the DOE Idaho Operations Office (DOE-ID) is cognizant of the Shoshone-Bannock tribal members' need for access to areas on the INL Site for cultural and religious purposes.

The INL Site is located primarily in Butte County; however, it also occupies portions of Bingham, Bonneville, Clark, and Jefferson counties. The 2000 census indicated the following populations for cities in the region: Idaho Falls-50,730; Pocatello-51,466; Blackfoot-10,419; Arco-1,026; and Atomic City-25.

Surface water flows on the INL Site consist mainly of three streams draining intermountain valleys to the north and northwest of the INL Site: (1) the Big Lost River, (2) the Little Lost River, and (3) Birch Creek. All of the channels terminate on the INL Site. Flows from Birch Creek and the Little Lost River seldom reach the INL Site because of irrigation withdrawals upstream. The Big Lost River and Birch Creek may flow onto the INL Site before the irrigation season or during high-water years, but the terminal reaches are usually dry. In those few wetter years when the Big Lost River carries water to the end of its channel, the water sinks into the ground.

The physical characteristics, climate, flora and fauna, demography, and cultural resources of the INL Site and Reactor Technology Complex area are further described in the Record of Decision (ROD) (DOE 2000).

\subsubsection{Power Burst Facility Location}

The PBF is located in the south-central portion of the INL (Figure 2-1) in the former Waste Experimental Reduction Facility/Waste Reduction Operations Complex/Power Burst Facility area, approximately $14.5 \mathrm{~km}$ (9 mi) east of the Central Facilities Area. 


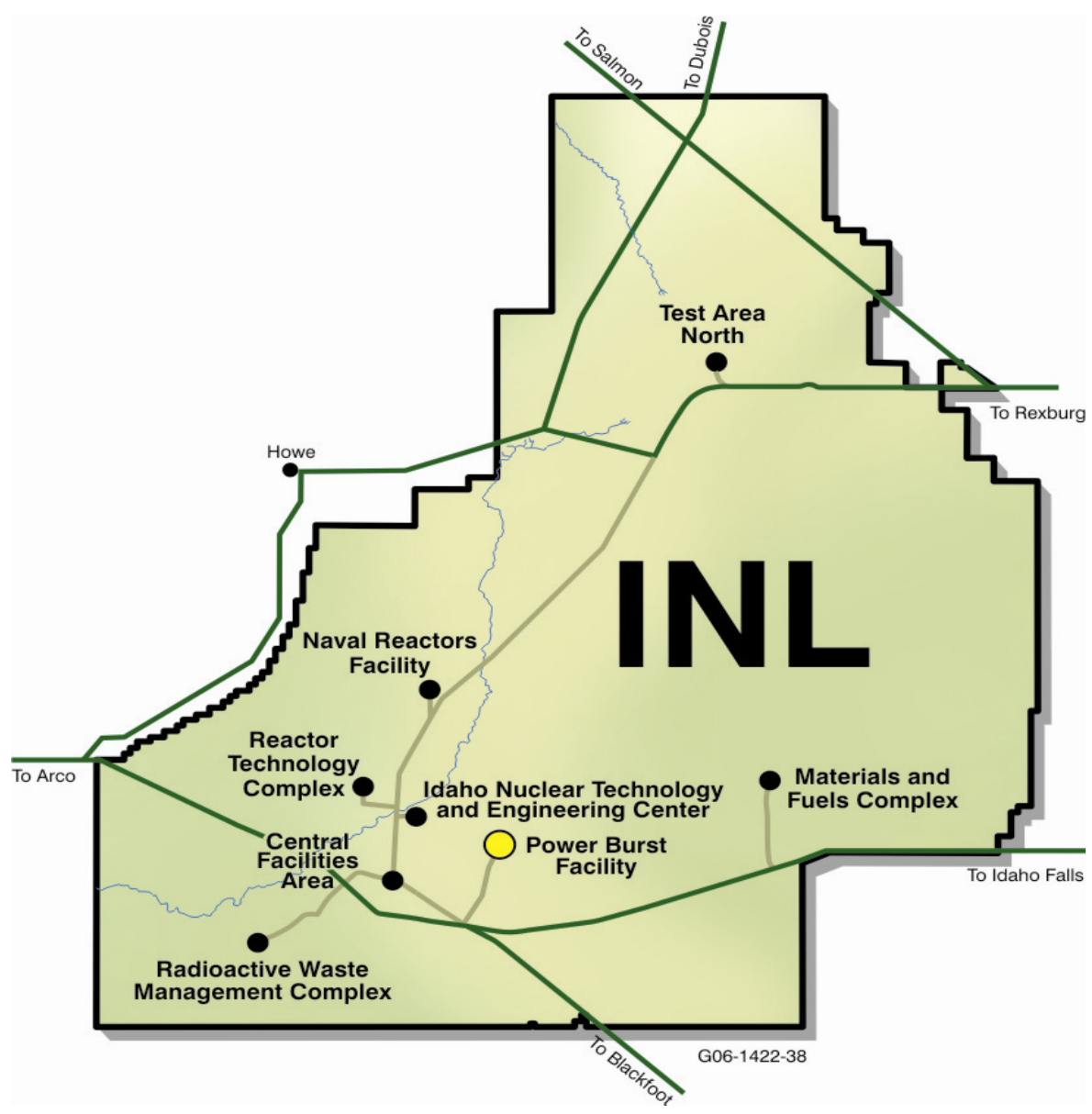

Figure 2-1. Location of PBF on the INL.

\subsubsection{Power Burst Facility Description}

Construction on PBF began in 1966 and was completed in 1971. It was operated from September 22, 1972, until February 7, 1985, achieving an integrated reactor power of 24,924.6 MW-hr. PBF was designed and built to perform experiments on nuclear fuel. Samples were exposed to transient and steady-state neutron fluxes to test fuel behavior under controlled accident conditions. The reactor core was located centrally in a stainless steel vessel (PBF vessel), which was filled with water. Experiments were contained in an Inconel 718 in-pile tube that occupied the central flux trap of the core and extended well above and below the core. The testing environment for the in-pile tube was provided by the pressurized water-coolant loop.

Unlike other test reactors that used beryllium to reflect neutrons, the PBF fuel rods were surrounded by a row of solid stainless steel reflector rods. There were eight boron carbide $\left(\mathrm{B}_{4} \mathrm{C}\right)$ control rods and four transient rods of similar construction used to control criticality and flux transients. The PBF fuel rods were removed from the facility in the summer of 2003 and placed in dry storage at the Idaho Nuclear Technology and Engineering Center. The in-pile tube was removed and disposed of at the ICDF in 2005. Figure 2-2 is a photo of PBF in its current configuration. 


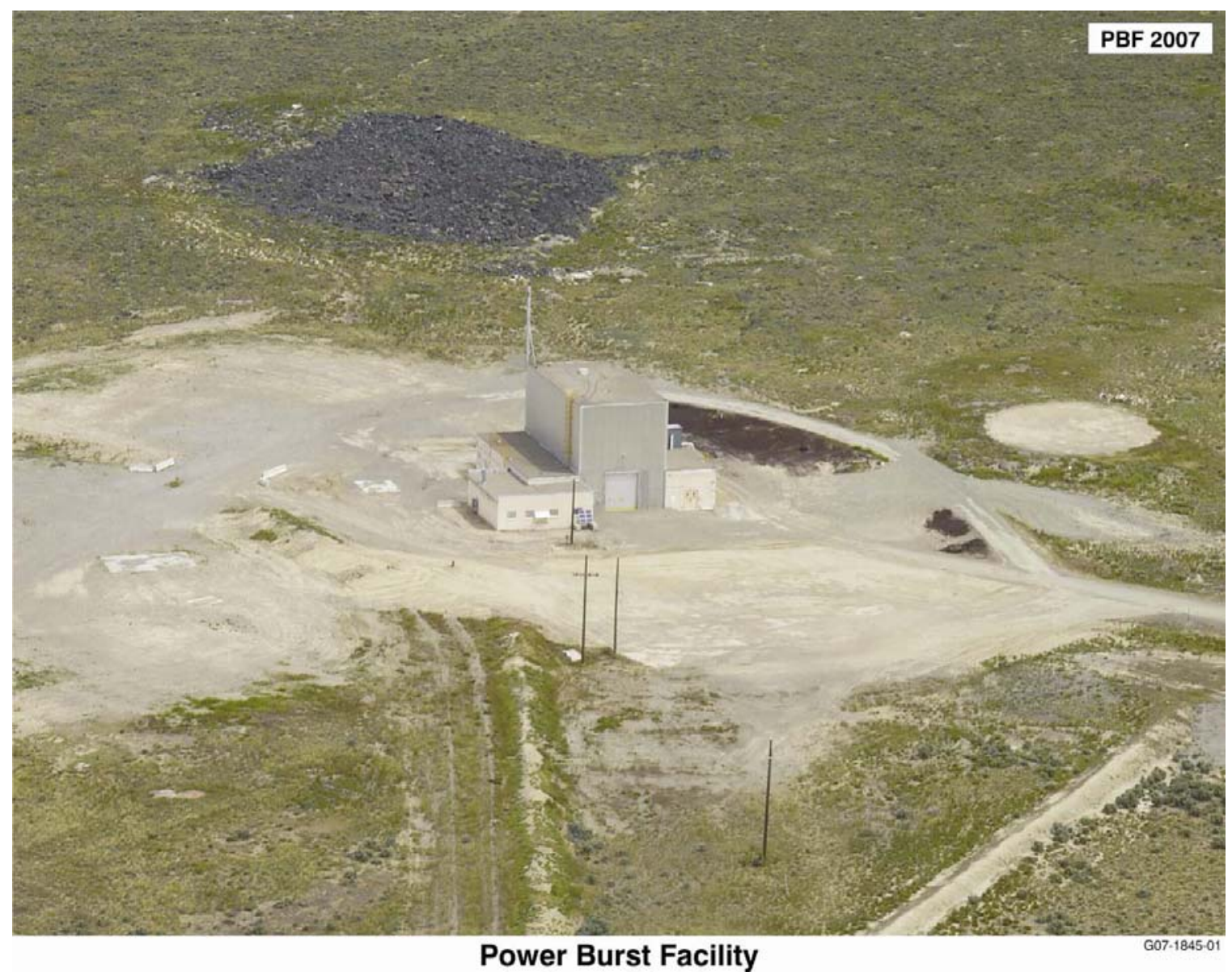

Figure 2-2. Photo of the Power Burst Facility (Power Excursion Reactor [PER]-620).

As shown in Figure 2-3, PBF consists of the main floor, which sits at approximately ground level; the first basement, which extends to approximately $20 \mathrm{ft}$ below ground level; and the second basement, which extends approximately $40 \mathrm{ft}$ below ground level. The loop cubicles are located on the north side of the first basement. There are two cubicles with a sample room between them. The main function of this chamber was to process the experimental loop coolant. Behind Cubicle 10 is the sampling room, and easternmost, behind the sampling room, is Cubicle 13, which housed the blow-down tank, the fission product detector system, and other functions. The second basement contained the subpile room, waste gas room, knockout drum room, and warm waste sump room.

The PBF reactor building houses the reactor vessel, fuel storage canal, and various process systems that supported reactor operations. The structure is a two-story, steel-frame building that has steel plate interior with aluminum exterior siding and two block-wall wings (east and west). The building is divided into a main reactor high-bay room, two single-story wings containing instrumentation and electrical control equipment, various support offices, operational and utility areas, and a two-level basement. 


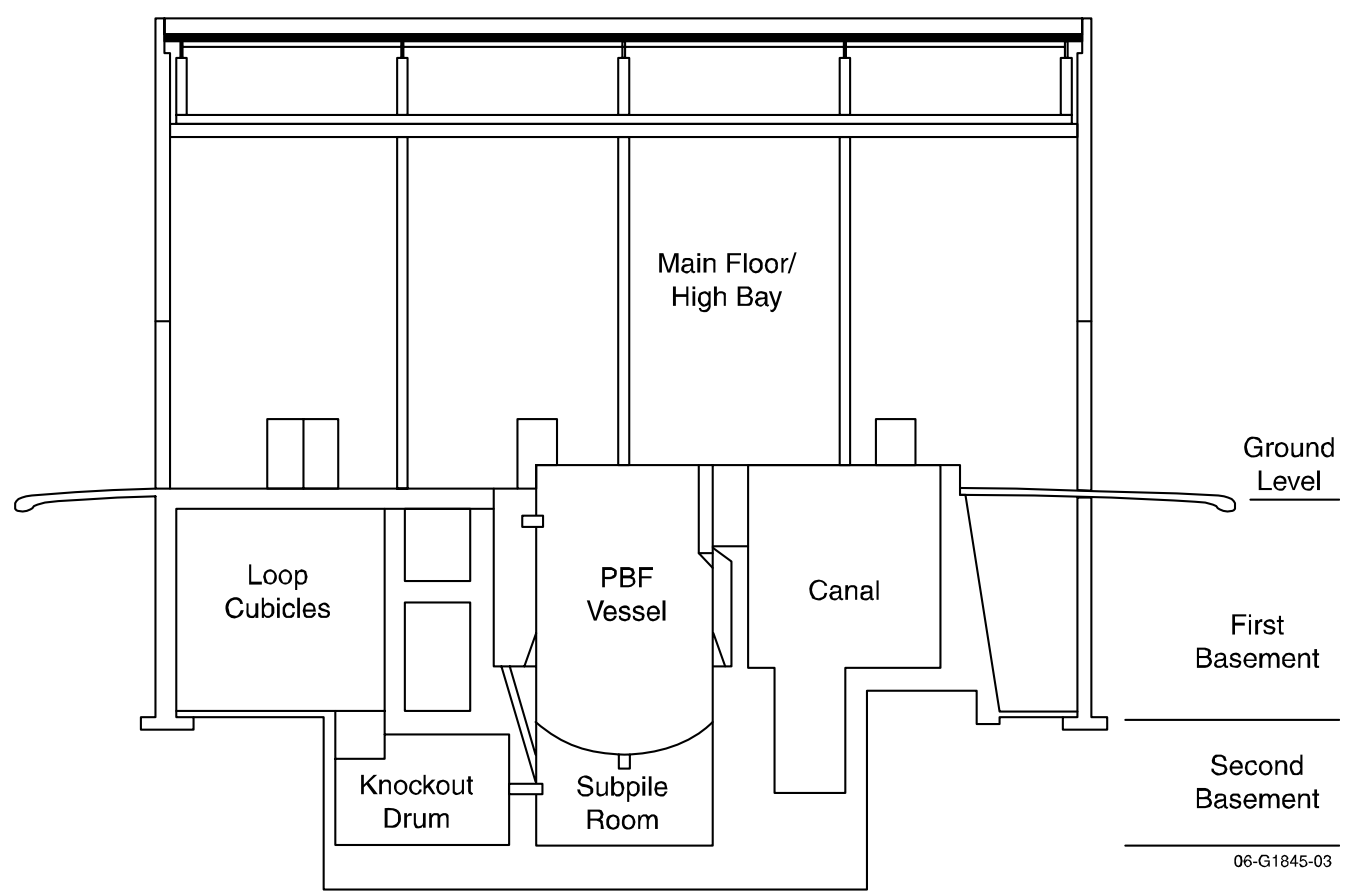

Figure 2-3. Cutaway rendering of the PBF (PER-620) looking east.

2.1.3.1 PBF Vessel. The PBF vessel (Figures 2-4 and 2-5) is constructed entirely of Type 304 stainless steel. The overall vessel length is approximately $30 \mathrm{ft}$ and the vessel is approximately $15 \mathrm{ft}$ in diameter with a $1 / 2$-in.-thick wall. The vessel is supported by a "skirt" that increases the diameter of the vessel to nearly $18 \mathrm{ft}$. The approximate total weight of the vessel and internals is $113,300 \mathrm{lb}$ (56.7 tons).

The internals of the vessel include transient and control rod assemblies (rods and guide tubes), core support grid, flow skirt, core side plates, and support structures. Two nozzles, protruding from the bottom of the vessel, provided the primary coolant inflow and outflow. A rectangular opening in the south side of the vessel connects with the PBF storage canal. Fuel rods, the in-pile tube, and other components were transferred underwater between the vessel and the canal through this vessel opening. A reinforced carbon steel cover was installed on the top vessel opening in 2005.

The vessel contains no hazardous waste, beryllium, asbestos, or PCBs. The vessel internals are constructed of stainless steel, aluminum, and $\mathrm{B}_{4} \mathrm{C}$. The vessel and canal were drained of primary coolant water in 2005. 


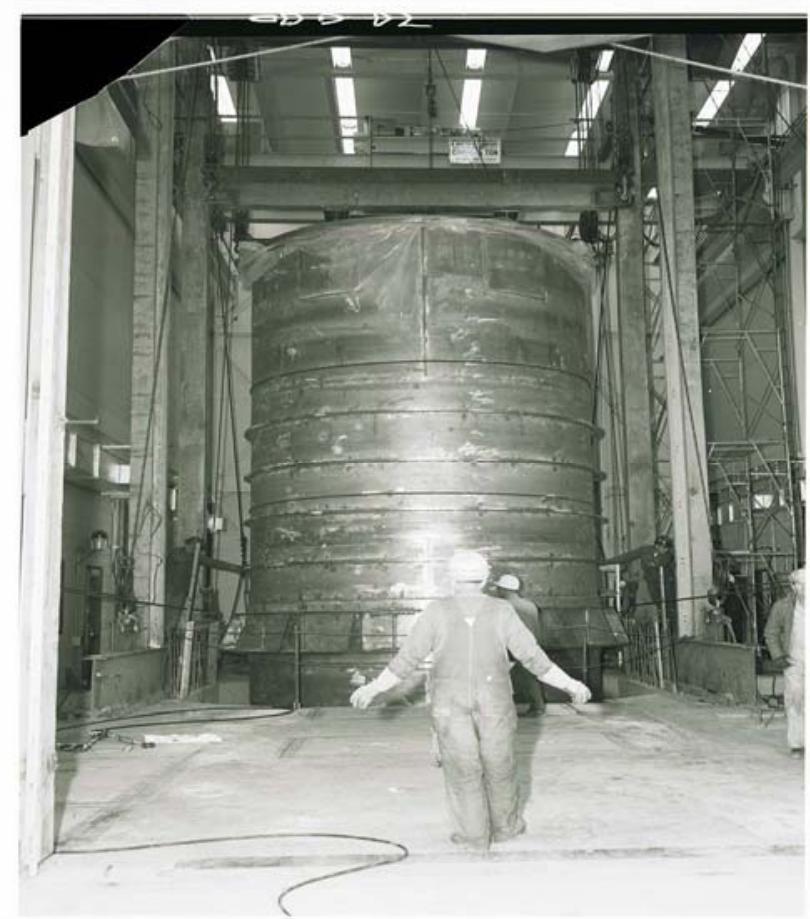

Figure 2-4. Power Burst Facility Vessel Installation 1970.

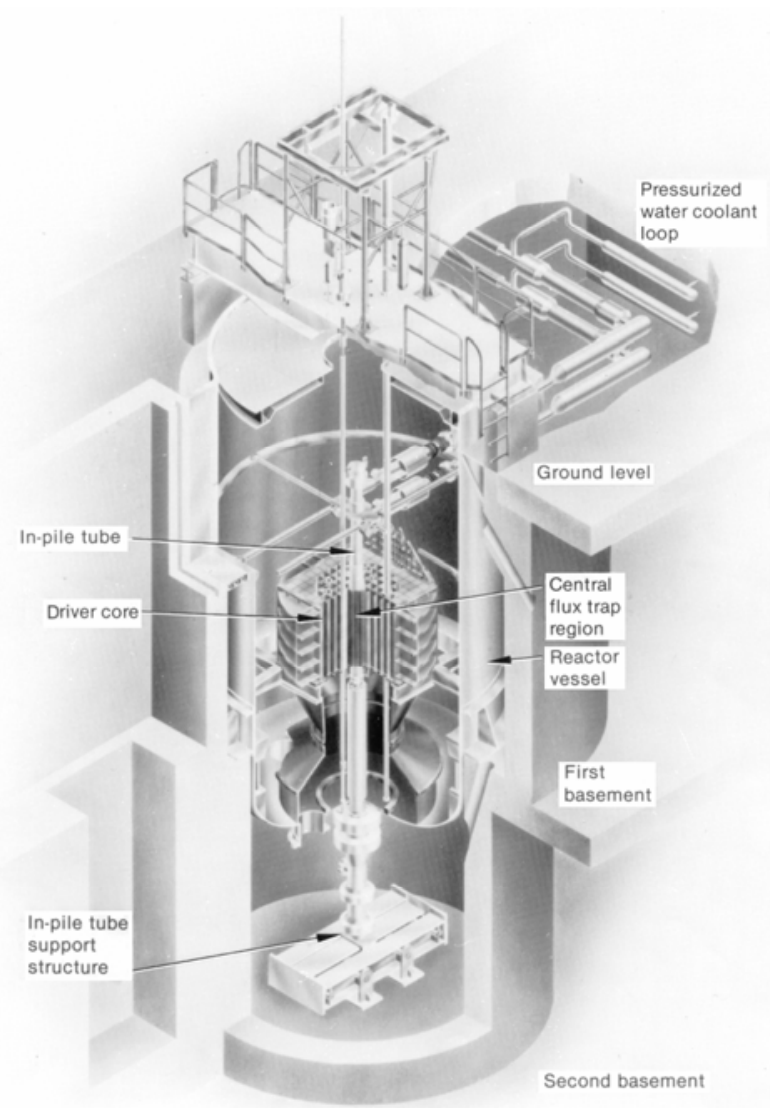

Figure 2-5. Cutaway rendering of the PBF vessel (in-pile tube dispositioned to ICDF). 


\subsection{Previous Closure/Cleanup Activities at PBF}

\subsubsection{PBF Deactivation Activities}

The PBF reactor was placed on operational standby in 1985 and the fuel rods were removed in the summer of 2003. Deactivation of the PBF canal began in October 2003. Canal Deactivation Project activities consisted of removing materials and equipment from the fuel storage canal and placing the canal in a stable, low-risk condition. Deactivation included the removal of activated fuel canisters, activated stainless-steel shim and reflector rods, aluminum filler rods, fuel rod storage racks, ion and fission chambers, a seismic support system for racks, fixed equipment, a plutonium-beryllium reactor startup source, canal water, corrosion coupons, sediment, and debris. All liquid-bearing systems were isolated. Divers were placed into the canal to seal weld the canal gate into place to isolate the reactor from the canal. In addition to installing the canal gate, the divers removed and cleaned loose radiological contamination from the walls and floor of the canal and applied a fixative to the canal walls and floors. The water was cleaned by filtering and was pumped out to the PER-706 evaporation tank. Canal Deactivation Project activities were completed in August 2004.

\subsubsection{Voluntary Consent Order Activities}

In September 2004, actions were completed at PBF under the Voluntary Consent Order (VCO) between DOE and DEQ. The INL characterized a total of 44 items that were considered as potential Hazardous Waste Management Act/Resource Conservation and Recovery Act (HWMA/RCRA) waste at the time the VCO was signed. Of those, 38 were then analyzed and characterized as nonhazardous. Materials that were removed under the VCO program included approximately $38,000 \mathrm{lb}$ of lead, two panel-mounted air-conditioning units, and oil from two pump systems.

\subsubsection{Comprehensive Environmental Response, Compensation, and Liability Act Activities at the PBF}

Remedial investigations and activities under CERCLA have been ongoing in the PBF area since 1991, beginning with the investigation and remedial activities conducted as part of the FFA/CO (DOE-ID 1991) and continuing with three NTCRAs. The first NTCRA, PBF Phase 1, occurred in 2005 and put the facility in an interim end state. The second is decommissioning activities preparatory to the final end state. This NTCRA will be the third and final one, and will take PBF to the final end state with vessel disposition. CERCLA activities are discussed in more detail below.

2.2.3.1 Federal Facility Agreement and Consent Order Activities. The Operable Unit (OU) 5-12 ROD (DOE-ID 2000) selected a remedy for the cleanup of identified contaminated soil at PBF and the Auxiliary Reactor Area (ARA). All FFA/CO remedial actions have been completed at PBF/ARA and, as required under CERCLA whenever waste is left in place, institutional controls have been implemented for residual contaminants left in place at concentrations that would not allow for unrestricted use or access. This final end state NTCRA will implement the remedial action objectives (RAOs) developed in the OU 5-12 ROD (DOE-ID 2000).

2.2.3.2 PBF Phase 1 NTCRA. This first phase of the PER-620 decommissioning was evaluated in the Engineering Evaluation/Cost Analysis for the Phase 1 of the Decommissioning for the Power Burst Facility Reactor Building (PER-620), (DOE/NE-ID 2004). This EE/CA addressed those activities that could be completed prior to a scheduled INL contract end date (April 2005) for the Idaho Closure Project and before the Idaho Cleanup Project under CWI took responsibility for decommissioning (May 2005). These actions placed PBF in an interim end state and reduced overall surveillance and maintenance costs at the facility. 
Decommissioning work accomplished during Phase 1 NTCRA resulted in the following interim end state for the PBF complex, which consisted of the PER-620 reactor building, out-buildings for storage backup generators and compressed air and the PER-706 evaporation tank:

- $\quad$ All buildings and structures external to PER-620 were demolished to grade.

- $\quad$ PER-620 was drained of all liquids including the primary and secondary coolant. The warm waste tank (PER-632) was drained and the liquids were solidified and disposed of.

- $\quad$ Over 235,000 lbs of lead was removed from PER-620 and either recycled or sent off-Site for disposal. Cadmium sheeting was removed from Cubicle 13 and disposed of off-Site.

- $\quad$ The in-pile tube in the PBF vessel was removed and disposed of at the ICDF.

- A carbon steel cover was installed over the PBF vessel.

- All utilities to and from the PER-620 building were isolated including potable water, fire water, electricity, and sewer.

Phase 1 was completed at the end of April 2005 with the exception of the demolition of the PER-706 evaporation tank. The liquids in the tank, mostly primary and secondary coolant water, were allowed to evaporate during the summer and fall of 2005. The remaining liquid and sediment was disposed of at the ICDF and the tank was demolished in November 2005.

\subsubsection{Decommissioning Preparatory Activities}

Removal activities are currently ongoing at PBF in accordance with the Action Memorandum for General Decommissioning Activities under the Idaho Cleanup Project (DOE/ID 2006). That document allows "decommissioning preparatory activities" to go forth in the "more substantial and significant facilities" such as PBF, but specifically excludes end-state decisions. Work being conducted as decommissioning preparatory activities includes:

- Hazardous Waste Removal: Hazardous waste - such as mercury vapor lamps and fluorescent bulbs, lead shielding (bricks, sheets, shot), circuit boards containing lead and/or silver soldering, and waste regulated under the Toxic Substances Control Act (TSCA) (15 USC § 2601 et seq.) such as PCB articles and equipment (e.g., transformers, capacitors, and fluorescent lighting ballasts might contain PCBs) - is removed and disposed of.

- $\quad$ Asbestos Abatement Activities: Removal of friable asbestos found in pipe and tank/vessel insulation, fire doors, transite panels, and other potential asbestos-containing material, as required under 40 CFR 61.145, "Standard for Demolition and Renovation."

- Removal of Other Support Systems and Components from PBF: Electrical cabinets, hoods, sinks, mixing tanks, and counters; the ion exchange columns from Cubicle 10, the warm waste room, and the demineralizer system; and radioactive contaminated piping and tanks from throughout the facility are being removed. 


\subsubsection{Other Remedial Activities at PBF}

In June 2002, during routine measuring of an underground heating fuel storage tank located adjacent to the PBF reactor building, an unanticipated decrease in the product level was noticed that suggested that the tank (PER-722) might have released fuel to the subsurface. Further investigation confirmed that heating oil was released from the tank to the subsurface. The remaining heating fuel product was removed from the tank, and the tank was closed in accordance with the appropriate federal, state, and local regulations. Characterization studies, including the installation of borings and a monitoring well completed in the Snake River Plain Aquifer, demonstrated that the aquifer was not impacted by the release. Groundwater monitoring at this site will continue through 2007. 


\section{PBF CONTAMINANT INVENTORIES}

The following sections describe the radionuclide and chemical contamination used in the risk assessments presented in this EE/CA. The contaminant estimates are based on sampling, radiological surveys including gamma scans and modeling. PBF vessel activity values, due to activation, are based on MCNP4C and ORIGEN2 computer codes. These computer codes are used to estimate the effects of neutron fluxes produced by the reactor during operation on the metals that are present in the vessel.

Although radiological and chemical contamination present in PBF is being removed under the decommissioning preparatory activities, material and contamination estimates used in this EE/CA were generally estimates of what was in PBF prior to starting these activities. These materials and contamination were included in the risk evaluations to ensure a conservative approach was taken for determining risk to human health, groundwater, and the environment for the proposed end-state alternatives evaluated in this EE/CA.

\subsection{Radiological Contaminants}

PBF contains a variety of radiological contaminants that make up the radiological inventory. These contaminants are derived from the activation or transmutation of metals such as aluminum and stainless steel, and equipment piping and building surfaces contaminated with activation and fission products. Table 3-1 presents the total estimated radioactive contamination at the end of the Phase 1 NTCRA and before the beginning of decommissioning preparatory activities at PBF.

Radioactivity is measured in a unit of activity called a Curie (Ci). Activity is the rate a radiological isotope will decay emitting ionizing particles such as alpha and beta particles or energy such as gamma rays. The estimated radionuclide inventory for PBF in the above ground level interval is $5.11 \mathrm{Ci}$ and the below ground level inventory is $43.9 \mathrm{Ci}$. Therefore, the total source term for PBF is approximately $49 \mathrm{Ci}$, of which $21.8 \mathrm{Ci}$ resides in the PBF vessel.

Figure 3-1 depicts the approximate distribution of the radioactive contamination in Curies and the approximate contamination from Cesium-137, the primary human health risk driver, in that interval. This figure includes all radiological contamination including those that are present in the PBF vessel.

Appendix A presents an estimate of the total radionuclides present in PBF and the activity of each isotope. Appendix B presents the estimated contamination at PBF in the $0 \mathrm{ft}$ to $10 \mathrm{ft}$ below ground level interval. Understanding the contamination in this interval is important to determine the risk to a hypothetical future resident and will be further discussed in the risk assessment sections later in this $\mathrm{EE} / \mathrm{CA}$. Appendix $\mathrm{C}$ provides a list of isotopes and activities for radionuclides in the above ground level interval of the PBF.

\subsubsection{PBF Vessel Contaminants}

The PBF vessel contains both activation products from the neutron fluxes received by vessel components during operation, and loose and fixed contamination from fission products released during fuel testing. Appendix D provides a listing of the components that make up the vessel and an estimate of the specific contaminants that are present in that component. There is an estimated total of $21.8 \mathrm{Ci}$ of activity in the PBF vessel. 
Table 3-1. Total radiological source term by location in PBF.

\begin{tabular}{|c|c|c|c|c|c|}
\hline Location & Item & $\begin{array}{c}\text { Surface Area } \\
\left(\mathrm{m}^{2}\right)\end{array}$ & $\begin{array}{c}\text { Total Source } \\
\text { Term } \\
\text { (Ci) } \\
\end{array}$ & $\begin{array}{c}\text { Above } \\
\text { Ground Level } \\
\text { Source Term } \\
\text { (Ci) }\end{array}$ & $\begin{array}{c}\text { Below } \\
\text { Ground Level } \\
\text { Source Term } \\
\text { (Ci) }\end{array}$ \\
\hline \multirow[t]{4}{*}{ PBF vessel } & Activated Components & NA & $2.18 \mathrm{E}+01$ & & $2.18 \mathrm{E}+01$ \\
\hline & Internal Contamination & 130.65 & 8.94E-05 & $6.99 \mathrm{E}-06$ & $8.24 \mathrm{E}-05$ \\
\hline & \multirow[t]{2}{*}{ External Contamination } & 131.50 & $1.67 \mathrm{E}-03$ & $1.49 \mathrm{E}-04$ & $1.52 \mathrm{E}-03$ \\
\hline & & Totals $=$ & $2.18 \mathrm{E}+01$ & $1.56 \mathrm{E}-04$ & $2.18 \mathrm{E}+01$ \\
\hline \multirow[t]{5}{*}{ Cubicle 10} & Resin Beds & & $8.39 \mathrm{E}+00$ & & $8.39 \mathrm{E}+00$ \\
\hline & Hot Spots & & $1.01 \mathrm{E}-03$ & & $1.01 \mathrm{E}-03$ \\
\hline & Piping and Components & & $3.19 \mathrm{E}+00$ & & $3.19 \mathrm{E}+00$ \\
\hline & \multirow[t]{2}{*}{ Cubicle Surfaces } & 224.6 & $1.46 \mathrm{E}-01$ & & $1.46 \mathrm{E}-01$ \\
\hline & & Total $=$ & $1.17 \mathrm{E}+01$ & & $1.17 \mathrm{E}+01$ \\
\hline \multirow[t]{5}{*}{ Cubicle 13} & Hot Spots & NA & $1.14 \mathrm{E}+00$ & & $1.14 \mathrm{E}+00$ \\
\hline & Cubicle Surfaces & 218 & 7.41E-01 & & $7.41 \mathrm{E}-01$ \\
\hline & Piping and Components & & $1.24 \mathrm{E}+00$ & & $1.24 \mathrm{E}+00$ \\
\hline & \multirow[t]{2}{*}{ Blowdown Tank } & & $5.70 \mathrm{E}-01$ & & $5.70 \mathrm{E}-01$ \\
\hline & & Totals $=$ & $3.69 \mathrm{E}+00$ & & $3.69 \mathrm{E}+00$ \\
\hline \multirow[t]{3}{*}{ Knockout Drum Room } & Room Surfaces & 117 & $3.98 \mathrm{E}-01$ & & $3.98 \mathrm{E}-01$ \\
\hline & \multirow[t]{2}{*}{ Piping and Components } & & $1.71 \mathrm{E}+00$ & & $1.71 \mathrm{E}+00$ \\
\hline & & Totals $=$ & $2.11 \mathrm{E}+00$ & & $2.11 \mathrm{E}+00$ \\
\hline \multirow[t]{5}{*}{ Warm/Hot Waste Room } & Permanent Resin Beds & & $1.52 \mathrm{E}-01$ & & $1.52 \mathrm{E}-01$ \\
\hline & Room Surfaces & 104.3 & $4.15 \mathrm{E}-04$ & & 4.15E-04 \\
\hline & Piping and Components & & $3.50 \mathrm{E}-01$ & & $3.50 \mathrm{E}-01$ \\
\hline & \multirow[t]{2}{*}{ Warm Waste Tank } & & $1.55 \mathrm{E}-01$ & & $1.55 \mathrm{E}-01$ \\
\hline & & Totals $=$ & $6.58 \mathrm{E}-01$ & & $6.58 \mathrm{E}-01$ \\
\hline Waste Gas Room & Room Surfaces & 133.4 & $2.40 \mathrm{E}-01$ & & $2.40 \mathrm{E}-01$ \\
\hline Main Floor & Room Surfaces & $1,622.8$ & $4.98 \mathrm{E}+00$ & $4.98 \mathrm{E}+00$ & \\
\hline First Basement & Room Surfaces & 926.7 & $9.99 \mathrm{E}-03$ & & $9.99 \mathrm{E}-03$ \\
\hline Second Basement & Room Surfaces & 707.4 & $5.38 \mathrm{E}-01$ & & $5.38 \mathrm{E}-01$ \\
\hline Sub-Pile Room & Room Surfaces & 73.9 & $1.18 \mathrm{E}+00$ & & $1.18 \mathrm{E}+00$ \\
\hline Sample Room & Room Surfaces & 167.3 & 4.98E-02 & & $4.98 \mathrm{E}-02$ \\
\hline \multirow[t]{2}{*}{ Annulus } & Surfaces & 139.6 & $1.95 \mathrm{E}-03$ & & $1.95 \mathrm{E}-03$ \\
\hline & Above-Grade Surfaces & 23.4 & $1.28 \mathrm{E}-04$ & $1.28 \mathrm{E}-04$ & \\
\hline $\begin{array}{l}\text { Piping and Components } \\
\text { in Remainder of Building }\end{array}$ & & & $2.04 \mathrm{E}+00$ & $1.36 \mathrm{E}-01$ & $1.90 \mathrm{E}+00$ \\
\hline & & Above Ground Leve & Source Term $=$ & $\begin{array}{l}5.11 \mathrm{E}+00 \\
(5.11)\end{array}$ & $\mathrm{Ci}$ \\
\hline & & Below Ground Leve & Source Term $=$ & $\begin{array}{l}4.39 \mathrm{E}+01 \\
(43.9)\end{array}$ & $\mathrm{Ci}$ \\
\hline & & Tota & Source Term $=$ & $\begin{array}{l}4.90 \mathrm{E}+01 \\
(49.0)\end{array}$ & $\mathrm{Ci}$ \\
\hline
\end{tabular}




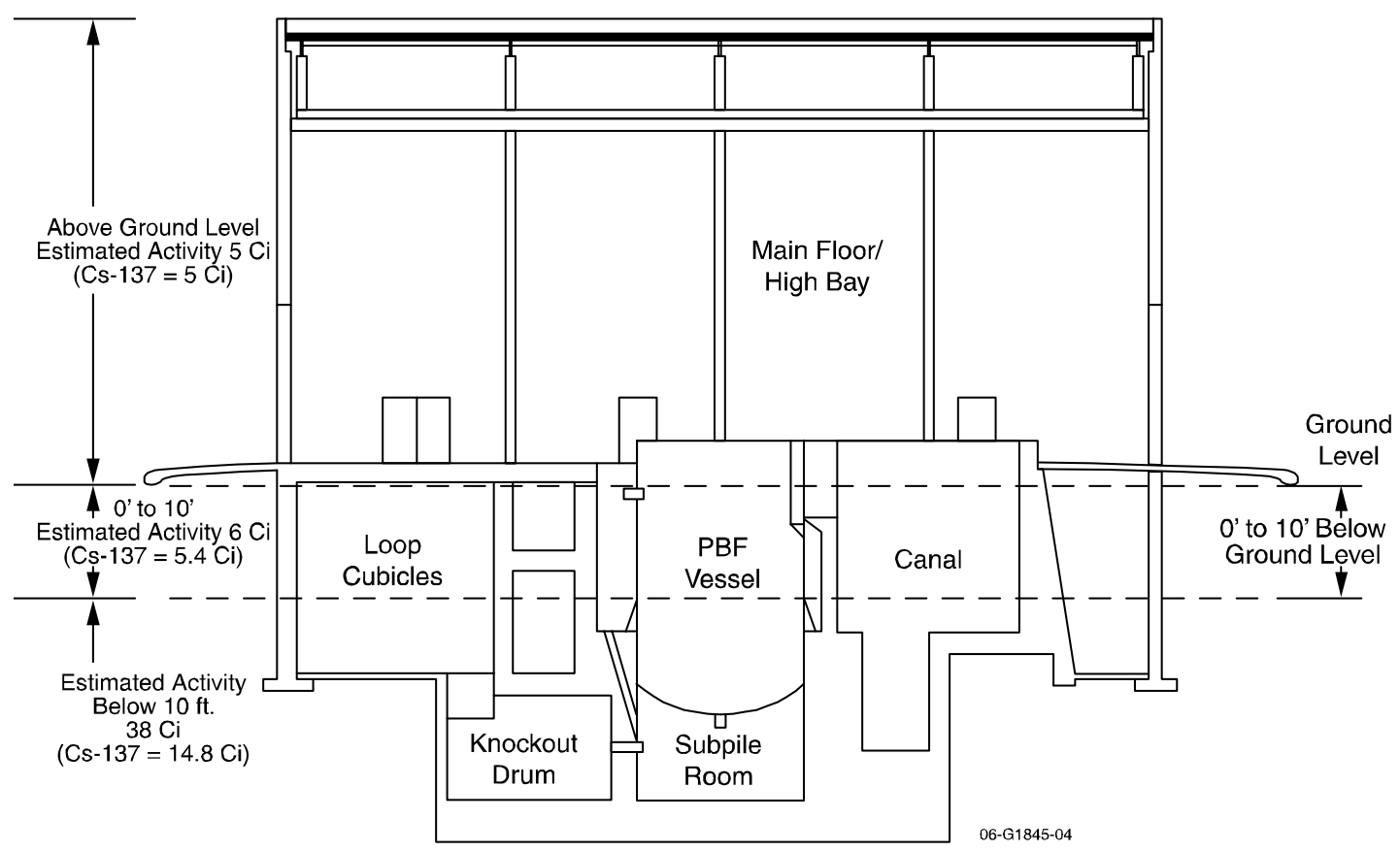

Figure 3-1. Radiological distribution in the PBF.

Based on the PBF vessel's radiological source term, the vessel meets the ICDF waste acceptance criteria for disposal. Since the ICDF is a DOE waste disposal facility, Nuclear Regulatory Commission (NRC) waste classification requirements are not applicable. However, for comparison, the PBF vessel would be classified as NRC Class A low-level waste. None of the radiological constituents individually exceed the Class A threshold values nor does the sum of the ratios of all constituents exceed the threshold. Also, the vessel is not classified as transuranic waste. NRC waste classifications such as Class A waste are used to determine how radioactive waste should be packaged, transported, and disposed of. For example, because the PBF vessel is NRC Class A waste, it would not require further additional analysis for disposal at ICDF. Transuranic waste is generally waste that contains radiological isotopes that have an atomic number greater than Uranium (atomic number 92), emit alpha particles, and take many years to decay to a nonhazardous form. Disposal of these wastes is generally limited to disposal at the Waste Isolation Pilot Plant in New Mexico. Since the PBF vessel contains less than 10 nano Ci (nano is a billionth of a curie), then it is not considered transuranic for the purposes of disposal at the ICDF.

Direct radiological readings of the PBF vessel were taken in January 2007. The vessel no longer contained primary coolant so the readings taken were not affected by the shielding effects of water. The highest dose rate on the outside of the vessel was $560 \mathrm{mrem} /$ hour and the highest measured in the vessel was $1.8 \mathrm{R} / \mathrm{hr}$. Modeling was used to determine the potential maximum dose rate in the vessel core area, and the results indicate $6.4 \mathrm{R} /$ hour.

\subsection{PBF Chemical Constituents}

For purposes of this EE/CA, an estimate of the inventory of nonradiological chemical constituents was prepared to perform risk analyses and to predict the migration potential of these materials to a future source of drinking water. Table 3-2 shows the estimated chemical constituent quantities in PBF (includes PBF vessel materials). 
Table 3-2. Estimated inventory of chemical constituents in the below-ground levels of the PBF.

\begin{tabular}{|c|c|c|c|c|}
\hline Material & Location & Use & Form & $\begin{array}{l}\text { Quantity } \\
(\mathrm{kg})\end{array}$ \\
\hline Aluminum & $\begin{array}{l}\text { Various basement } \\
\text { locations, subpile } \\
\text { room }\end{array}$ & $\begin{array}{l}\text { Material of } \\
\text { construction }\end{array}$ & Ducting, platforms & 2,041 \\
\hline Boron & Reactor vessel & Neutron absorber & $\begin{array}{l}\text { Boron carbide in PBF } \\
\text { vessel poison rods }\end{array}$ & 164 \\
\hline $\begin{array}{l}\text { Chromium, } \\
\text { Cr III }\end{array}$ & $\begin{array}{l}\text { Throughout } \\
\text { basement levels }\end{array}$ & $\begin{array}{l}\text { Metal alloy for } \\
\text { construction of } \\
\text { stainless and carbon } \\
\text { steel }\end{array}$ & $\begin{array}{l}\text { Piping, tanks, structural } \\
\text { steel }\end{array}$ & 21,750 \\
\hline Lead & $\begin{array}{l}\text { Throughout } \\
\text { basement levels }\end{array}$ & $\begin{array}{l}\text { Anchoring and } \\
\text { shielding }\end{array}$ & $\begin{array}{l}\text { Small amounts of } \\
\text { inaccessible lead wool } \\
\text { around piping } \\
\text { penetrations, also as alloy } \\
\text { of concrete wall anchors, } \\
\text { pipe packing, and brass } \\
\text { alloy }\end{array}$ & 50 \\
\hline Manganese & $\begin{array}{l}\text { Throughout } \\
\text { basement levels }\end{array}$ & $\begin{array}{l}\text { Material of } \\
\text { construction }\end{array}$ & Piping, tanks & 2,172 \\
\hline Nickel & $\begin{array}{l}\text { Throughout } \\
\text { basement levels }\end{array}$ & $\begin{array}{l}\text { Material of } \\
\text { construction }\end{array}$ & Piping, tanks, PBF vessel & 11,070 \\
\hline Selenium & $\begin{array}{l}\text { Rectifiers on } \\
\text { annulus exterior wall }\end{array}$ & Cooling fin coating & Plating/coating & 0.030 \\
\hline Uranium metal & Not specified & Failed fuel rods & Fuel fragments & 1.109 \\
\hline Zinc & $\begin{array}{l}\text { Throughout } \\
\text { basement levels }\end{array}$ & $\begin{array}{l}\text { Alloy for the } \\
\text { construction of brass } \\
\text { and bronze valves } \\
\text { and piping }\end{array}$ & Brass and bronze pieces & 454 \\
\hline
\end{tabular}

As discussed in Section 2.2, Previous Closure/Cleanup Activities at PBF, removal of liquids, items that could be considered HWMA/RCRA hazardous waste, asbestos, and chlorofluorocarbons has been completed or will be complete when PBF reaches its final end state, as determined by the NTCRA process. Table 3-2 lists the inventory at the end point of the Phase 1 NTCRA with the exception of lead which has been corrected down to $50 \mathrm{~kg}$ to approximate the lead that will be remaining at the completion of the ongoing preparatory to decommissioning activities.

The greatest quantities of materials are those used in the construction of equipment and components for nuclear operations (primarily stainless steel), including the PBF vessel and components, piping, valves, and tanks; and materials required to provide necessary radiation shielding for nuclear operations. Thus, most of the mass accounted for in this inventory consists of chromium and nickel, which are the principal alloys (for hardening and corrosion resistance) in stainless steel. 


\section{RISK ANALYSIS}

Three risk analyses have been performed to determine future risk to humans, the groundwater, and the environment.

\subsection{Human Health Risk Analysis}

Risks from contamination that might be left in place were evaluated by considering worst case contaminant source terms in place at PBF at the completion of the Phase 1 NTCRA. The approach used for the human health assessment considered a "no action" scenario at PBF. In this scenario, all components, piping, and building structures would remain in place without monitoring or maintenance. This risk scenario assumed that any contamination remaining after radioactive decay will be mixed uniformly in the top $10 \mathrm{ft}(3.05 \mathrm{~m})$ of soil over an area the size of the PBF footprint $\left(6,695 \mathrm{ft}^{2} / 622 \mathrm{~m}^{2}\right)$ which will be available to a resident beginning in the year 2095 ( 88 years from present).

This risk analysis is consistent with the risk assumptions and methodologies presented in the ROD (DOE 2000), which are predicated on the current and future land uses established for the PBF area and include industrial land use until at least 2095 and possible residential land use thereafter. Under the residential scenario, it is assumed a person builds a house adjacent to the reactor building and is exposed to the contaminated soil in the same manner as if the house were built on the contaminated soil. The person will live at the site for 30 years, including six years of childhood, while being exposed to external radiation and to contamination through soil ingestion, fugitive dust inhalation, and ingestion of contaminated fruits and vegetables grown near the house. Standard EPA risk assessment equations were used to calculate the risks from radiological and nonradiological chemical constituents. For radionuclides, these equations cover intakes via ingestion of soil (small children) and homegrown produce, inhalation of resuspended soil, and external exposure to ionizing radiation. Exposures are then combined with risk factors (toxicity data) to assess overall risk. For nonradionuclide chemical constituents, only the soil ingestion and inhalation pathways are evaluated. Engineering Design File (EDF) -7433, Streamlined Risk Assessment for D\&D of the PBF Reactor Facility, provides more details regarding the risk analysis including assumptions, uncertainties, and equations used to calculate exposure.

The results of the risk analysis will be used in Section 7, Alternative Analysis, of this EE/CA.

\subsubsection{Human Health Risk Analysis for Radionuclides}

Radionuclides were screened using the Soil Screening Guidance for Radionuclides: User's Guide (EPA 2000a). Soil screening levels (SSLs) in pCi/g — based on a 1E-06 cancer risk-were calculated using equations in the guidance for (1) soil ingestion, (2) ingestion of homegrown produce grown in contaminated soil, (3) inhalation of windblown dust, and (4) external exposure. The lowest SSL for each radionuclide was compared to soil concentrations calculated using the inventories presented in Appendix B and C of this EE/CA and the PBF footprint $0 \mathrm{ft}$ to $10 \mathrm{ft}$ soil volume. Table 4-1 below presents the resultant radionuclide concentrations and the highlighted isotopes indicate those isotopes that exceeded the SSLs. These isotopes were then decayed to 2095 and input to risk assessment calculations.

The results of the human health risk analysis are presented in Table 4-2 and provide a summary of risk by radionuclide and pathway for the "no action" scenario. Cs-137 with daughter $(+D)$ products exceeded the regulatory risk range used by EPA for an acceptable lifetime cancer risk range between 10-4 and 10-6 for an individual exposure to carcinogens. Cs-137 exceeds the upper risk threshold of one excess cancer risk in 10,000 (10-4) persons with an excess risk of 6 in 1,000 (6-03). 
Table 4-1. Radionuclide soil concentrations compared to soil screening levels (2005 inventories).

\begin{tabular}{|c|c|c|c|c|}
\hline \\
\hline & $\begin{array}{l}\text { Total } \\
(\mathrm{Ci})\end{array}$ & $\begin{array}{c}\text { Soil } \\
\begin{array}{c}\text { Concentration } \\
(\mathrm{pCi} / \mathrm{g})\end{array} \\
\end{array}$ & $\begin{array}{l}\text { Lowest } \\
\text { SSL }\end{array}$ & $\begin{array}{c}\text { Exceeds } \\
\text { SSL? }\end{array}$ \\
\hline Ac-227 & 7.47E-09 & $2.62 \mathrm{E}-06$ & $2.08 \mathrm{E}+00$ & No \\
\hline $\mathrm{Ag}-108 \mathrm{~m}$ & 4.63E-11 & $1.62 \mathrm{E}-08$ & $1.55 \mathrm{E}-02$ & No \\
\hline Ag-110m & $2.21 \mathrm{E}-09$ & $7.75 \mathrm{E}-07$ & $8.58 \mathrm{E}-03$ & No \\
\hline Am-241 & $3.54 \mathrm{E}-03$ & $1.24 \mathrm{E}+00$ & $3.66 \mathrm{E}+00$ & No \\
\hline Am-243 & $1.60 \mathrm{E}-07$ & $5.60 \mathrm{E}-05$ & $1.18 \mathrm{E}+00$ & No \\
\hline Be-10 & $2.97 \mathrm{E}-11$ & $1.04 \mathrm{E}-08$ & $3.45 \mathrm{E}+01$ & No \\
\hline C-14 & $2.50 \mathrm{E}-09$ & $8.76 \mathrm{E}-07$ & $1.28 \mathrm{E}-01$ & No \\
\hline Ce-144 & $1.26 \mathrm{E}-11$ & 4.41E-09 & $2.22 \mathrm{E}+00$ & No \\
\hline $\mathrm{Cl}-36$ & $1.44 \mathrm{E}-13$ & $5.06 \mathrm{E}-11$ & $1.59 \mathrm{E}-02$ & No \\
\hline CM-243 & $8.66 \mathrm{E}-08$ & $3.03 \mathrm{E}-05$ & $2.66 \mathrm{E}-01$ & No \\
\hline CM-244 & 4.63E-07 & $1.62 \mathrm{E}-04$ & $4.38 \mathrm{E}+00$ & No \\
\hline CM-245 & $1.82 \mathrm{E}-11$ & $6.38 \mathrm{E}-09$ & 4.69E-01 & No \\
\hline CM-246 & $3.48 \mathrm{E}-13$ & $1.22 \mathrm{E}-10$ & $3.74 \mathrm{E}+00$ & No \\
\hline CM-247 & $9.88 \mathrm{E}-20$ & $3.46 \mathrm{E}-17$ & $8.52 \mathrm{E}-02$ & No \\
\hline CM-248 & $2.18 \mathrm{E}-20$ & $7.63 \mathrm{E}-18$ & $3.26 \mathrm{E}+03$ & No \\
\hline $\mathrm{Co}-60$ & $1.87 \mathrm{E}-08$ & $6.54 \mathrm{E}-06$ & $9.00 \mathrm{E}-03$ & No \\
\hline Cs-134 & $9.30 \mathrm{E}-05$ & $3.26 \mathrm{E}-02$ & $1.57 \mathrm{E}-02$ & Yes \\
\hline Cs- $137+D$ & $1.05 \mathrm{E}+01$ & $3.69 \mathrm{E}+03$ & $4.38 \mathrm{E}-02$ & Yes \\
\hline Eu-152 & $1.87 \mathrm{E}-04$ & $6.53 \mathrm{E}-02$ & $2.11 \mathrm{E}-02$ & Yes \\
\hline $\mathrm{Eu}-154$ & $2.52 \mathrm{E}-03$ & $8.84 \mathrm{E}-01$ & $1.91 \mathrm{E}-02$ & Yes \\
\hline I-129 & $1.32 \mathrm{E}-06$ & $4.62 \mathrm{E}-04$ & $2.19 \mathrm{E}-01$ & No \\
\hline Mn-54 & $6.15 \mathrm{E}-14$ & $2.15 \mathrm{E}-11$ & $2.87 \mathrm{E}-02$ & No \\
\hline $\mathrm{Nb}-94$ & $1.19 \mathrm{E}-11$ & $4.16 \mathrm{E}-09$ & $1.53 \mathrm{E}-02$ & No \\
\hline $\mathrm{Ni}-59$ & $4.86 \mathrm{E}-11$ & $1.70 \mathrm{E}-08$ & $7.24 \mathrm{E}+01$ & No \\
\hline $\mathrm{Ni}-63$ & $1.37 \mathrm{E}-06$ & $4.81 \mathrm{E}-04$ & $2.96 \mathrm{E}+01$ & No \\
\hline $\mathrm{Np}-237$ & 4.37E-08 & $1.53 \mathrm{E}-05$ & $8.49 \mathrm{E}-01$ & No \\
\hline $\mathrm{Pa}-231$ & 7.17E-09 & $2.51 \mathrm{E}-06$ & $6.23 \mathrm{E}-01$ & No \\
\hline $\mathrm{Pb}-210$ & $9.59 \mathrm{E}-10$ & $3.36 \mathrm{E}-07$ & $1.19 \mathrm{E}-01$ & No \\
\hline $\mathrm{Pu}-238$ & $2.80 \mathrm{E}-05$ & $9.82 \mathrm{E}-03$ & $2.92 \mathrm{E}+00$ & No \\
\hline $\mathrm{Pu}-239$ & $1.40 \mathrm{E}-04$ & $4.91 \mathrm{E}-02$ & $2.88 \mathrm{E}+00$ & No \\
\hline $\mathrm{Pu}-240$ & $4.07 \mathrm{E}-05$ & $1.43 \mathrm{E}-02$ & $2.87 \mathrm{E}+00$ & No \\
\hline $\mathrm{Pu}-241$ & $5.37 \mathrm{E}-04$ & $1.88 \mathrm{E}-01$ & $2.41 \mathrm{E}+02$ & No \\
\hline $\mathrm{Pu}-242$ & $3.13 \mathrm{E}-09$ & $1.10 \mathrm{E}-06$ & $3.02 \mathrm{E}+00$ & No \\
\hline $\mathrm{Pu}-244$ & $6.81 \mathrm{E}-18$ & $2.38 \mathrm{E}-15$ & $2.70 \mathrm{E}+00$ & No \\
\hline Ra-226 & $9.74 \mathrm{E}-10$ & $3.41 \mathrm{E}-07$ & $6.85 \mathrm{E}-02$ & No \\
\hline Ru-106 & $1.18 \mathrm{E}-09$ & 4.14E-07 & $1.15 \mathrm{E}-01$ & No \\
\hline
\end{tabular}


Table 4-1. (continued).

\begin{tabular}{|l|c|c|c|c|}
\hline & $\begin{array}{c}\text { Total } \\
(\mathrm{Ci})\end{array}$ & $\begin{array}{c}\text { Soil } \\
\text { Concentration } \\
(\mathrm{pCi} / \mathrm{g})\end{array}$ & $\begin{array}{c}\text { Lowest } \\
\text { SSL }\end{array}$ & $\begin{array}{c}\text { Exceeds } \\
\text { SSL? }\end{array}$ \\
\hline Sb-125 & $3.34 \mathrm{E}-04$ & $1.17 \mathrm{E}-01$ & $6.16 \mathrm{E}-02$ & Yes \\
\hline Sr-90 & $4.59 \mathrm{E}-01$ & $1.61 \mathrm{E}+02$ & $4.92 \mathrm{E}-02$ & Yes \\
\hline Tc-99 & $9.61 \mathrm{E}-06$ & $3.37 \mathrm{E}-03$ & $7.04 \mathrm{E}-02$ & No \\
\hline Th-228 & $1.24 \mathrm{E}-09$ & $4.36 \mathrm{E}-07$ & $2.75 \mathrm{E}+00$ & No \\
\hline Th-229 & $5.37 \mathrm{E}-14$ & $1.88 \mathrm{E}-11$ & $4.96 \mathrm{E}-01$ & No \\
\hline Th-230 & $5.59 \mathrm{E}-08$ & $1.96 \mathrm{E}-05$ & $6.67 \mathrm{E}+00$ & No \\
\hline Th-232 & $3.17 \mathrm{E}-16$ & $1.11 \mathrm{E}-13$ & $5.97 \mathrm{E}+00$ & No \\
\hline U-232 & $1.77 \mathrm{E}-09$ & $6.20 \mathrm{E}-07$ & $1.46 \mathrm{E}+00$ & No \\
\hline U-233 & $2.38 \mathrm{E}-11$ & $8.34 \mathrm{E}-09$ & $5.81 \mathrm{E}+00$ & No \\
\hline U-234 & $3.00 \mathrm{E}-04$ & $1.05 \mathrm{E}-01$ & $5.02 \mathrm{E}+00$ & No \\
\hline U-235 & $1.35 \mathrm{E}-05$ & $4.74 \mathrm{E}-03$ & $2.15 \mathrm{E}-01$ & No \\
\hline U-236 & $2.88 \mathrm{E}-07$ & $1.01 \mathrm{E}-04$ & $5.33 \mathrm{E}+00$ & No \\
\hline U-238 & $3.92 \mathrm{E}-06$ & $1.37 \mathrm{E}-03$ & $6.50 \mathrm{E}+00$ & No \\
\hline Zn-65 & $2.55 \mathrm{E}-11$ & $8.94 \mathrm{E}-09$ & $3.97 \mathrm{E}-02$ & No \\
\hline SSL = soil screening level & & \\
\hline
\end{tabular}

Table 4-2. Results of radionuclide risk by pathway.

\begin{tabular}{|c|c|c|c|c|c|}
\hline Radionuclides & Soil Ingestion & Inhalation & $\begin{array}{l}\text { External } \\
\text { Exposure }\end{array}$ & $\begin{array}{c}\text { Food } \\
\text { Ingestion }\end{array}$ & SUM \\
\hline Cs-134 & 8.E-27 & 2.E-31 & 7.E-24 & 4.E-26 & 7.E-24 \\
\hline Cs- $137+D$ & 1.E-05 & 3.E-10 & 5.E-03 & 7.E-05 & 6.E-03 \\
\hline Eu-152 & 3.E-12 & 1.E-15 & 7.E-09 & 6.E-13 & 7.E-09 \\
\hline Eu-154 & 2.E-12 & 6.E-16 & 3.E-09 & 4.E-13 & 3.E-09 \\
\hline $\mathrm{Sb}-125+\mathrm{D}$ & 2.E-22 & 2.E-26 & 2.E-19 & 8.E-24 & 2.E-19 \\
\hline \multirow[t]{2}{*}{ Sr-90+D } & 2.E-06 & 1.E-10 & 2.E-06 & 5.E-05 & 6.E-05 \\
\hline & & & & & 6.E-03 \\
\hline
\end{tabular}

In order to reduce the Cs-137 risk to $1 \mathrm{E}-04$, the present Cs-137 inventory would require reduction by approximately 53 times, from the existing $10.5 \mathrm{Ci}$ to approximately $0.2 \mathrm{Ci}$. No other radionuclides in the existing (no action) inventory would present an unacceptable risk.

\subsubsection{Chemical Constituent Risk Analysis}

The chemical constituent inventory associated with PBF is described in Section 3.2. Soil concentrations were calculated given the PBF soil volume in the $0 \mathrm{ft}$ to $10 \mathrm{ft}$ interval and the chemical constituent inventories listed in Table 4-3. 
Table 4-3. PBF Chemical constitution soil concentrations.

\begin{tabular}{lc}
\hline Aluminum & $\begin{array}{c}\text { Mass } \\
(\mathrm{kg})\end{array}$ \\
Boron & $2.04 \mathrm{E}+03$ \\
Chromium, Cr-III & $1.64 \mathrm{E}+02$ \\
Lead & $2.18 \mathrm{E}+04$ \\
Manganese and comp. & $5.00 \mathrm{E}+01$ \\
Nickel (soluble salts) & $2.17 \mathrm{E}+03$ \\
Selenium & $1.11 \mathrm{E}+04$ \\
Uranium metal & $3.00 \mathrm{E}-02$ \\
Zinc & $1.11 \mathrm{E}+00$ \\
\hline
\end{tabular}

The chemical constituent concentrations were then screened for human health using EPA's Soil Screening Guidance: User's Guide (EPA 1996). SSLs were calculated, using equations in the Guidance, for both carcinogen and non-carcinogen chemical constituents. The soil ingestion and inhalation pathways were considered in this screening. The result of the screening is presented in Table 4-4. Only nickel did not pass the soil screening and is evaluated further for human risk.

Table 4-4. Results of screening nonradiological contaminants.

\begin{tabular}{lc}
\hline & $\begin{array}{c}\text { Soil Concentration } \\
\text { Exceeds SSL? }\end{array}$ \\
\hline Aluminum & $\mathrm{NA}^{\mathrm{a}}$ \\
Boron & No \\
Chromium, Cr-III & No \\
Lead & $\mathrm{No}^{\mathrm{b}}$ \\
Manganese and comp. & No \\
Nickel (soluble salts) & Yes \\
Selenium & No \\
Uranium metal & No \\
Zinc & No
\end{tabular}

a. There are no SSLs or EPA action levels for aluminum.

b. Soil lead concentrations would be below the $400 \mathrm{mg} / \mathrm{kg}$ EPA action level.

Highlighted constituent exceeded SSL.

Nickel was the only chemical constituent that exceeded the initial screening criteria. Both carcinogenic and non-carcinogenic risk were then calculated for nickel and resulted in values below criteria of 1E-04 (carcinogenic) and the hazard index (HI) (noncarcinogenic) threshold of 1 (Table 4-5). Therefore, the risks from existing (no action) inventories of chemical constituents at PBF would not exceed the regulatory accepted levels for the future resident. Table 4-5 summarizes the results of the chemical constituent risk analysis. 
Table 4-5. Risk results for the metal nickel.

\begin{tabular}{|l|l|}
\hline $\begin{array}{l}\text { Carcinogenic Risk } \\
\text { (Fugitive Dust Inhalation) }\end{array}$ & $1 \mathrm{E}-06$ \\
\hline $\begin{array}{l}\text { Non-Carcinogenic Risk } \\
\text { (Soil Ingestion) }\end{array}$ & 0.7 \\
\hline $\begin{array}{l}\text { a. To be compared with EPA cancer risk criterion of 1E-04. } \\
\text { b. To be compared with EPA hazard index criterion of 1. }\end{array}$ \\
\hline
\end{tabular}

\subsection{Groundwater Risk Analysis}

The EDF-4869, Groundwater Pathway Risk Assessment for the PBF Closure, was performed in 2004 for the Phase 1 NTCRA and used the groundwater pathway risk assessment code GWSCREEN (Rood 2003). The assumed source term for the assessment was that all contaminant inventories were left in place including the PBF vessel, the highly irradiated in-pile tube, and all HWMA/RCRA hazardous wastes including over 200 tons of lead. The assessment included the assumption that the lower levels of PBF were backfilled or grouted consistent with Alternative 3 described later in this EE/CA. This screening level risk assessment showed no unacceptable groundwater pathway risk.

Since that time, the radionuclide inventory estimates have been refined with additional characterization, and some contaminated components at PBF have been removed (e.g., the in-pile tube). The revised inventory is documented in EDF-7000, Power Burst Facility (PBF) Below and Above Grade Source Terms. Estimates of the inventory of some of the nonradionuclide chemical constituents, such as lead, have decreased significantly since the 2004 groundwater pathway risk assessment. The conclusions of the 2004 risk assessment bound the current PBF inventories for the nonradionuclide chemical constituents and therefore were not further analyzed.

EDF-7618, Groundwater Pathway Risk Assessment for the PBF Closure-2007 Update, evaluates the revised radionuclide inventory presented in EDF-7000. The 2007 update used a two phase screening approach. The first phase uses the dose screening approach presented in the National Council on Radiation Protection (NCRP) Report No. 123 (NCRP 1996) to eliminate radionuclides with predicted radiological doses that are very small. Radionuclides that were not eliminated based on the NCRP dose screening, were evaluated in the second screening phase using a Track 2 (DOE-ID 1994) screening level approach.

Based on the PBF streamlined risk assessment, the predicted groundwater concentrations meet the required performance criteria. For groundwater, the performance criteria are to prevent migration of contaminants from the PBF facility that would cause the Snake River Plain Aquifer to exceed a cumulative carcinogenic risk level of $1 \times 10^{-4}$ or applicable State of Idaho groundwater quality standards (which are equivalent to the Clean Water Act maximum contaminant levels [MCLs]) in 2095 and beyond. From a cumulative risk standpoint, this streamlined risk assessment demonstrates that leaving radionuclides in place at $\mathrm{PBF}$ would not result in a significant contribution to the cumulative risk in the vicinity of PBF. The predicted future concentrations of contaminants in the aquifer as a result of leaving PBF contaminants in place, are orders of magnitude below the risk-based concentrations corresponding to the RAOs defined in the Operable Unit 5-12 Remedial Investigation/Feasibility Study (DOE-ID 1999). 


\subsection{Ecological Risk Analysis}

The screening level ecological risk assessment followed the approach presented in the Guidance Manual for Conducting Screening Level Ecological Risk Assessments at the INEL (VanHorn, Hampton, and Morris 1995) and documented in the Comprehensive Remedial Investigation/Feasibility Study for Waste Area Groups 6 and 10 Operable Unit 10-04 (DOE-ID 2001) and the Risk-Based Screening and Assessment Report for Waste Area Group 1 Soils (Van Horn and Stacey 2004). Contaminants of potential concern that exceeded screening were evaluated further in EDF-7433.

The streamlined ecological risk assessment was performed to support the "no action" scenario for the PBF Reactor Facility. This evaluation used a screening approach to evaluate risk to ecological receptors. The same soil concentrations used for the human health risk analysis were used for this analysis. These concentrations were screened to ecological-based levels that have been shown or calculated to have a detrimental effect on specific flora and fauna. The screening for radionuclides indicated that ecological-based screening levels are not exceeded for any radionuclide.

In the initial screen, the nonradionuclide chemical constituents were evaluated, and boron, chromium III, lead, manganese, and zinc exceeded the ecological-based screening levels for the "no action" alternative. The inclusion of these constituents in the overall soil concentration is a highly conservative assumption. In the environment at this site, items such as wiring, piping, and stainless-steel debris will not degrade to a bioavailable form uniformly throughout this soil, as was modeled. Since the concentrations of contaminants of concern will be highly localized, it is unreasonable to assume they would pose a risk to ecological receptors at a population level. Therefore, the nonradiological materials are eliminated as an ecological concern. 


\section{IDENTIFICATION OF REMOVAL OBJECTIVES}

The OU 5-12 ROD (DOE-ID 2000) established RAOs for cleanup of contaminated soils at the PBF area. This section identifies the removal action objectives that are consistent with the ROD RAOs for the activities associated with this removal action.

\subsection{Removal Action Objectives}

Although PBF is not specifically addressed in the OU 5-12 ROD (DOE-ID 2000), the removal action objectives listed below are consistent with or more conservative than RAOs for contaminated soil established in the ROD. The removal action objectives also are predicated on the current and future land uses established for the PBF area in the ROD, which include industrial land use until at least 2095 and possible residential land use thereafter. Actions conducted under this non-time-critical removal action would be reviewed with DEQ and EPA for continued protectiveness during the CERCLA five-year reviews of the remedy for OU 5-12. The removal action objectives for the final end state of PBF are:

- Inhibit direct exposure to radionuclide contaminants of concern remaining at PBF that would result in a total excess cancer risk greater than or equal to 1 in 10,000 for current workers and future residents.

- Inhibit dermal adsorption of contaminants of concern remaining at PBF that would result in a total excess cancer risk greater than or equal to 1 in 10,000 or an $\mathrm{HI}$ of 1 or greater for future residents. To maintain consistency with other CERCLA risk assessments done at the INL and ensure conservatism is maintained in the risk evaluations, the HI of 1 was used in place of the HI of 2 specified in the OU 5-13 ROD.

- Inhibit exposure to contaminated soil that would pose a risk to an ecological receptor.

In addition to the remediation objectives established through the FFA/CO process, the selected alternative should incorporate the DOE goal of reducing the "risk footprint" by consolidating wastes in the ICDF and reducing surveillance and maintenance costs on legacy buildings and structures. 


\section{IDENTIFICATION OF REMOVAL ACTION ALTERNATIVES FOR PBF}

The three alternatives under consideration for the PBF NTCRA are discussed in the following sections.

\subsection{Alternative 1-No Action}

Under the "no action" alternative, no removal action would be conducted at PBF and there would be no further surveillance and maintenance at the facility. Under this alternative, radiological and nonradiological chemical constituents remaining at the completion of the 2005 PBF Phase 1 NTCRA would be assumed to remain in place to become available to human and ecological receptors.

\subsection{Alternative 2-Grouting PBF Vessel in Place}

For Alternative 2, the PBF vessel would remain in place and be filled with grout and the above ground portions of the vessel would be encapsulated in a concrete monolith. The above ground level reactor building would be demolished. Below ground level structures and systems, including piping, utility systems, and structural steel, may be abandoned in place. In addition, residual radioactive materials in PBF would remain in place and would be managed under the Sitewide Institutional Control Program. Void spaces would be grouted as necessary and/or backfilled as practicable using inert demolition waste from the above ground level structures and clean backfill materials. An estimated $42 \mathrm{Ci}$ of radionuclides, 19 of which are Cs-137, would remain below ground level. Figure 6-1 depicts the conceptual end state of Alternative 2 and the estimated radionuclides remaining at PBF.

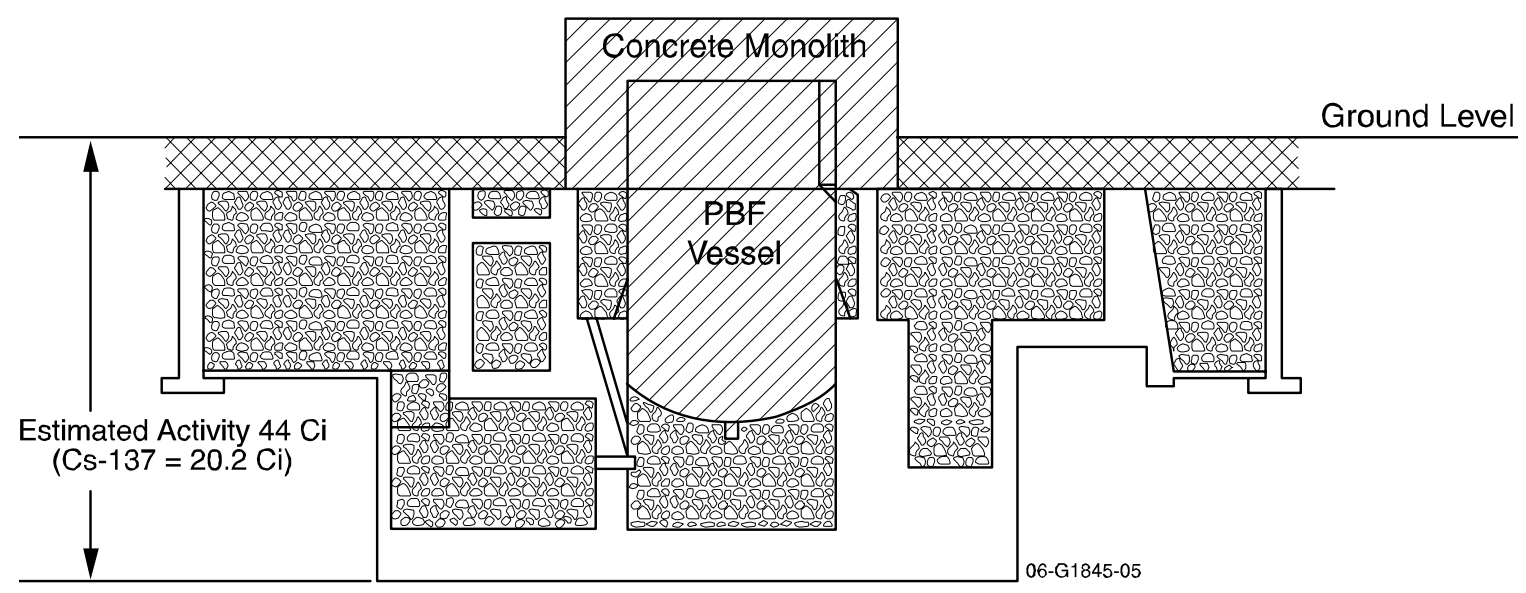

Existing concrete foundations and interior walls.

Backfill or grout

EA Grout/concrete

Clean backfill

Figure 6-1. Conceptual end state for PBF under Alternative 2. 


\subsection{Alternative 3-Removal and Disposal of PBF Vessel at the ICDF}

Alternative 3 would include removal and disposal of the PBF vessel at the ICDF. The reactor building would be demolished to below ground level; some structures and systems below ground level consisting of inert materials such as piping, tanks, structural metal, and utility systems, may be abandoned in place if they do not present an unacceptable risk to human health, groundwater, or environmental receptors. Residual radioactive materials at PBF remaining after decommissioning and demolition (D\&D) activities are completed would stay in place and be managed under the Sitewide Institutional Control Program. Void spaces would be backfilled as practicable, including the void left by removal of the PBF vessel. Backfill would consist of grout, as necessary, and/or inert demolition waste from the above ground level structures and clean backfill materials. As shown in the conceptual end state of the alternative (Figure 6-2), less than $0.2 \mathrm{Ci}$ of total activity, including Cs-137, would remain from $0 \mathrm{ft}$ to $10 \mathrm{ft}$ below ground level. Approximately $4.7 \mathrm{Ci}$ of total activity would remain below the $10 \mathrm{ft}$ interval. The vessel would be grouted to stabilize the internal reactor components and to meet required disposal facility Waste Acceptance Criteria (WAC) (DOE-ID 2005) for reducing void space to prevent subsidence.

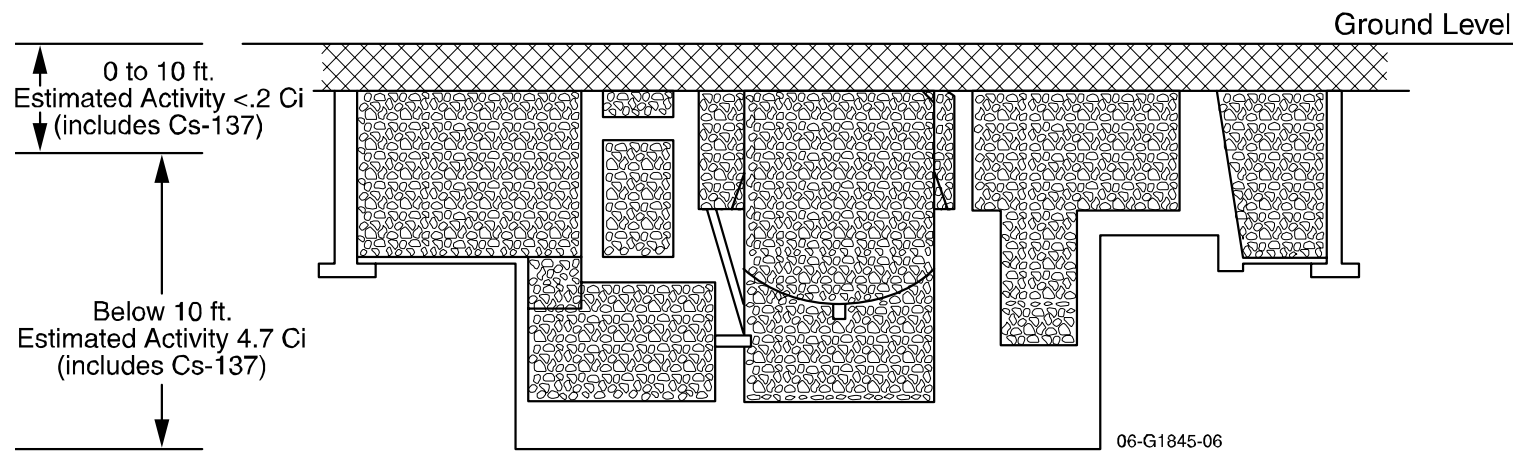

Existing concrete foundations and interior walls.

Backfill or grout

2 Clean backfill

Figure 6-2. Conceptual end state for PBF under Alternative 3. 


\section{ALTERNATIVE ANALYSIS}

In accordance with the Guidance on Conducting Non-Time Critical Removal Actions Under CERCLA (EPA 1993), the EE/CA's three NTCRA alternatives will be evaluated with respect to three criteria: (1) effectiveness, (2) implementability, and (3) cost.

Effectiveness includes two subcriteria: protectiveness and the ability to meet the removal action objectives. Protectiveness was evaluated based on (1) protectiveness of the alternative for public health and the community, (2) protectiveness of workers during implementation, (3) protectiveness of the environment, and (4) compliance with applicable or relevant and appropriate requirements (ARARs) and other requirements.

Implementability is evaluated based on technical feasibility; availability of equipment, personnel, services, and disposal facilities; and administrative feasibility. Costs are estimated, including capital costs, operations and maintenance costs, and present net worth costs.

Under the "no action" alternative, no removal action would be conducted at PBF and there would be no further surveillance and maintenance at the facility. Under this alternative, radiological and nonradiological chemical constituents remaining at the completion of the 2005 PBF Phase 1 NTCRA would be assumed to remain in place to become available to human and ecological receptors. The "no action" alternative is a hypothetical, conservative, baseline assumption, in that the sum of all identified chemical and/or radiological contamination, if not properly contained or controlled may be released to the environment causing an unacceptable risk to potential receptors (current and future workers, hypothetical future residents, and the environment). These assumptions are for comparative purposes only and do not reflect the DOE mandate to monitor, maintain, and mitigate potential or actual hazardous or radiological constituent releases to the public or the environment from any facility or site. In addition, Alternative 1 is only an interim measure that delays a needed future action; therefore, the alternative is not carried forward for the detailed analysis.

\subsection{Effectiveness of the Alternatives}

The two subcriteria for evaluating effectiveness are protectiveness and the ability to meet the RAOs.

\subsubsection{Protectiveness}

Protectiveness is the primary objective of a removal action and is a threshold criterion that must be met to recommend an alternative. The sections below address protectiveness for a future resident (public health), a current worker, and the environment.

7.1.1.1 Protectiveness: Public Health. Under Alternative 2, most of the below ground level building and piping would remain in place. The PBF vessel would also remain and be grouted. An estimated 5.9 $\mathrm{Ci}$ of activity from all radioactive isotopes remain in the $0 \mathrm{ft}$ to $10 \mathrm{ft}$ below ground level interval with an estimated 5.4 $\mathrm{Ci}$ of the total being Cs-137, the primary risk driver. As previously discussed in Section 4.1.1.1, Alternative 2 presents an unacceptable carcinogenic risk to a potential future resident at the location. The primary risk driver under Alternative 2 is the external exposure pathway resulting from Cs-137. Cs-137 is present as contamination on building surfaces and the internals of piping and tanks. Alternative 2 does not meet the threshold criteria of protectiveness for a future resident without land use restrictions remaining at the site beyond 2095. 
Alternative 3 requires removal of the PBF vessel and removal or decontamination of building surfaces and piping in the $0 \mathrm{ft}$ to $10 \mathrm{ft}$ interval to meet risk-based levels.

Since the PBF vessel meets ICDF WAC, placement of the PBF vessel at ICDF under Alternative 3 is more appropriate than leaving the vessel in place at PBF under Alternative 2. ICDF uses less conservative assumptions for establishing the future land use, as described in the OU 3-13 ROD (DOE-ID 1999), than is prescribed in the OU 5-12 ROD (DOE-ID 2000). Instead, the risk assessment for ICDF assumes that land use controls will prohibit future residential use indefinitely. Both potential risks to industrial workers and impacts to the aquifer were evaluated for ICDF and found to be acceptable. Additionally, with the PBF vessel removed as proposed under Alternative 3, risks to a future hypothetical resident at PBF were determined to be acceptable. Therefore, Alternative 3 meets the threshold criteria of protecting human health.

7.1.1.2 Protectiveness: Worker Risk. Compared to Alternative 3, Alterative 2 does not remove the vessel and much of the piping in the $0 \mathrm{ft}$ to $10 \mathrm{ft}$ interval. To complete this work under Alternative 3 , workers would be in close proximity to hoisting, rigging, and cutting activities. For this reason, Alternative 2 is more protective of the worker because they would be less exposed to industrial hazards and the ionizing effects of radiation.

7.1.1.3 Protectiveness: Environmental Risk. Alternative 2 is less protective of the environment because it leaves the PBF vessel and most of the metal piping and components in the $0 \mathrm{ft}$ to $10 \mathrm{ft}$ interval. The screening level ecological risk evaluation discussed in Section 4.1.3, indicated soil concentrations for some metals exceeded the ecological based criteria. Alternative 3 is more protective of the environment because it significantly reduces the metal loading of the soils at PBF.

Alternative 3 disposes of the vessel and much of the piping and metal components at the ICDF. The topmost portion of the vessel would reside roughly $20 \mathrm{ft}$ below the ground surface and be covered to grade, then a final cover more than $15 \mathrm{ft}$ thick would also be placed above the vessel, placing the PBF vessel roughly $35 \mathrm{ft}(10.7 \mathrm{~m})$ below the top of the cover. Therefore, disposal at ICDF is more protective for ecological receptors than leaving the vessel in place.

7.1.1.4 Protectiveness: Ability to Achieve Removal Action Objectives. Alternative 3 achieves the removal action objectives consistent with the OU 5-12 ROD (DOE-ID 2000) by removing and shipping the PBF vessel and most of the piping, which contains the contaminant inventory presenting the unacceptable risk, to an approved disposal facility. Alternative 2 does not satisfy the RAOs or DOE goals and is not carried forward in this part of the evaluation.

\subsection{Implementability of the Alternatives}

Implementability is evaluated based on technical and administrative feasibility and availability of equipment, personnel, services, and disposal facilities.

\subsubsection{Technical and Administrative Feasibility}

Alternative 3 is technically feasible. The methods for performing this activity can be planned and engineered using existing available knowledge and procedures that have been performed at the INL or elsewhere. 


\subsubsection{Availability of Equipment, Personnel, and Services}

Equipment to support Alternative 3 is either available at the INL or is commercially available. Cranes capable of heavy lifts greater than the combined weight of the PBF vessel, internals, and grout are commercially available. Multi-axle transport vehicles are available to transport weights in excess of 200 tons that the vessel and additional shielding may require.

Trained personnel are available to perform Alternative 3. Workers will be trained to perform the tasks safely, and mock-up situations will be used to gain proficiency. Adequate industrial safety controls are in place to protect workers. Additionally, the work force and management that will perform vessel removal have been selected for their previous experience and success doing similar work. It is the responsibility of every ICP employee or subcontractor to stop work if the worker feels exposed to an uncontrolled or unacceptable hazard. Every ICP employee or subcontractor has the right to stop work until hazards are mitigated and the work can be performed safely.

The "Occupational Radiation Protection" regulation (10 CFR 835) requires the ICP to develop and implement plans and measures to maintain occupational radiation exposures at As Low As Reasonably Achievable (ALARA) levels (10 CFR 835.101[c] and 10 CFR 835.1001). As applied to occupational radiation exposure, the ICP ALARA process does not require that exposures to radiological hazards be minimized without further consideration, but that such exposures be optimized by taking into account (1) the benefits arising out of the activity, (2) the detriments arising from the resultant radiation exposures, and (3) the controls to be implemented. The primary methods used to maintain exposures at ALARA levels are administrative controls (e.g., radiation work permits, personnel dose tracking, and access controls) and, engineering controls (e.g., temporary shielding, containment devices, and filtered ventilation systems) are used (as appropriate) to control individual exposures to radiation.

Specific hazards associated with implementation of Alternative 3 at PBF will be identified and mitigated using an integrated safety management process that has been shown to significantly minimize worker exposure to injury. Both administrative and engineering controls will be used to protect the workers. Administrative controls include barriers and signage to prohibit nonessential personnel from hazardous work areas at PBF. Accountability of employees and close supervision of employees by competent foreman that match employee's abilities with the tasks to be completed is one of the administrative controls that help workers to do work safely. Engineering controls at PBF include hoisting and rigging designed to lift loads such as the PBF vessel safely with significant safety margins designed into lifting lugs, slings and cranes that bare the load. Water may be added to the PBF vessel to provide additional shielding to protect the worker during piping and component removal near the vessel. A trained and experience health and safety staff is also independently monitoring work activities and function as an integral part of the work planning process to ensure controls are implemented in the procedures that the workers are required to follow.

On-Site or off-Site disposal or recycling services are available for most waste generated for all alternatives.

\subsection{Cost of the Alternatives}

Detailed cost estimates have been prepared for Alternatives 2 and 3. As discussed in Section 5.1, Alternative Analysis, Alternative 1, the "no action" alternative, cannot be considered a viable alternative because it does not meet the minimum requirement of protectiveness of human health or the environment, nor does it meet regulations requiring control of radioactive contaminants in the environment. Therefore, a cost estimate has not been included in this EE/CA for Alternative 1. 
The estimates were prepared in accordance with $A$ Guide to Developing and Documenting Cost Estimates During the Feasibility Study (EPA 2000b). Costs are calculated for both capital expenditures and future surveillance and maintenance expenses. In accordance with EPA guidance, the cost for the alternatives over time is calculated as present net worth costs, which are the costs in 2007 dollars.

Alternative 2 assumes maintenance of the concrete monolith over the PBF vessel would require ongoing surveillance and maintenance, including water sampling and analysis costs and well maintenance costs through the institutional control period. Surveillance and maintenance costs for Alternative 2 would likely go beyond the institutional control period for an indeterminable period of time so the year 2095 was used for comparative purposes.

Alternative 3 includes demolition of the above ground portion of PBF and the removal and disposal of the PBF vessel. Alternative 3 also includes the cost for transportation and disposal of the vessel at ICDF. Alternative 3 meets the remedial action objectives without land use restrictions beyond 2095; therefore, no surveillance and maintenance costs are included.

The information in the cost estimate summary is based upon the best available information regarding the anticipated scope of the removal action alternatives. Changes in the cost elements are likely to occur as a result of new information and data collected during the performance of the removal action. Major changes will be documented in the form of a memorandum placed into the Administrative Record file. This is an order-of-magnitude engineering cost estimate that is expected to be within +50 to $-30 \%$ of actual project cost. The cost estimate summary is presented in Table 7-1.

Table 7-1. Cost estimates for the viable removal action alternatives in 2007 dollars.

\begin{tabular}{|l|c|c|}
\hline \multirow{2}{*}{\multicolumn{1}{|c|}{ Feature }} & Alternative 2 & Alternative 3 \\
\cline { 2 - 3 } & Entomb PBF Vessel in Concrete Monolith & $\begin{array}{c}\text { Removal and Disposal of the } \\
\text { PBF Vessel at the ICDF }\end{array}$ \\
\hline D\&D Costs & $\$ 3.8 \mathrm{M}$ & $\$ 9.6 \mathrm{M}$ \\
\hline $\begin{array}{l}\text { Surveillance and } \\
\text { Maintenance Cost }\end{array}$ & $\begin{array}{c}\$ 11.7 \mathrm{M} \\
\text { (Based on an annul average cost of } \$ 140 \mathrm{~K})\end{array}$ & $\$ 0.0 \mathrm{M}$ \\
\hline $\begin{array}{l}\text { Total Estimated Cost of the } \\
\text { Alternative }\end{array}$ & $\$ 15.5 \mathrm{M}$ & $\$ 9.6 \mathrm{M}$ \\
\hline
\end{tabular}

\subsection{Summary of Alternative Evaluation}

Alternative 1, the "no action" alternative, is included for completeness and comparative purposes. However, the alternative only defers taking further action at PBF to a future date and does not address the potential for adverse threat to human health and potential threat of release of hazardous substances to the environment. Alternative 1 does not support the DOE goal of reducing the risk footprint and consolidation of wastes. It is not recommended for these reasons.

Alternative 2 grouts the PBF vessel in place. This alternative provides the most protection for the worker; however, it requires ongoing land use restrictions because wastes would be left in place above and immediately below ground level. Additionally, it does not meet the DOE goal of reducing the "risk footprint" by consolidating wastes and reducing surveillance and maintenance costs on legacy buildings and structures.

Alternative 3 removes the PBF vessel and demolishes the reactor building to below ground level. This alternative meets the RAOs established in the OU 5-12 ROD (DOE-ID 2000). 


\section{RECOMMENDED REMOVAL ACTION ALTERNATIVE}

The recommended alternative is Alternative 3, "Removal and Disposal of the PBF Vessel at ICDF." The reactor building would be demolished to below ground level; some structures and systems below ground level consisting of inert materials such as piping, tanks, structural metal, and utility systems, may be abandoned in place if they do not present an unacceptable risk to human health, groundwater, or environmental receptors. Residual radioactive materials in PBF remaining after D\&D activities are completed would stay in place and be managed under the Sitewide Institutional Control Program. Void spaces would be backfilled as practicable, including the void left by removal of the PBF vessel. Backfill would consist of grout, as necessary, and/or inert demolition waste from the above ground level structures and clean backfill materials.

At the end state of Alternative 3 (Figure 6-2), less than $5 \mathrm{Ci}$ of total activity would remain below ground level. This includes less than $0.2 \mathrm{Ci}$ of $\mathrm{Cs}-137$ remaining in the $0 \mathrm{ft}$ to $10 \mathrm{ft}$ interval to meet the removal action objective of protectiveness for a future resident. A radiological survey of the $0 \mathrm{ft}$ to $10 \mathrm{ft}$ below ground level will be conducted to ensure this cleanup level is obtained.

ICDF is a state-of-the-art, multiple-lined, monitored on-Site disposal facility that offers greater protection to human health and the environment than disposal at the unlined disposal cells. The vessel would be filled with grout (as necessary) to stabilize vessel internals and reduce radiological dose. The PBF vessel would be transported and disposed of as low-level radioactive waste at ICDF. Any remaining voids in the vessel would be filled with grout at the disposal site.

The PBF vessel meets the ICDF WAC and, when disposed of, the topmost portion of the PBF vessel would reside roughly $20 \mathrm{ft}$ below the ground surface and be covered to grade. A final cover more than $15 \mathrm{ft}$ thick would then be placed above the vessel, putting the PBF vessel roughly $35 \mathrm{ft}(10.7 \mathrm{~m})$ below the top of the cover. Therefore, for the external exposure pathway, disposal at ICDF is more protective for a future resident and an ecological receptor than leaving the vessel in place.

ICDF is the only on-Site disposal facility that accepts CERCLA waste generated at the INL. It provides many advantages for disposal of this waste.

- The leachate from disposed waste at ICDF is managed using a double geotextile liner for collection

- $\quad$ ICDF has a lowermost layer of compact clay to protect groundwater by capturing and holding contaminants to prevent migration if the geotextile liners should fail in the future

- $\quad$ The ICDF WAC was established based on conservative groundwater modeling and compatibility analysis

- $\quad$ ICDF is located out of the 100 -year floodplain

- $\quad$ Operational controls are in place to minimize void spaces and prohibit free liquids in the waste

- Wastes are treated as necessary to stabilize prior to disposal

- A groundwater monitoring system, which includes perched as well as aquifer wells, provides early detection of releases

- A waste placement tracking system records the location of the waste in the disposal cell if future retrieval becomes necessary 
- An engineered cover to minimize infiltration of precipitation into the wastes will eventually be added

- Access controls, monitoring, and maintenance will remain in place for as long as the contents of ICDF remain a threat to human health or the environment if uncontrolled.

The recommended alternative meets the proposed removal action objectives regarding long-term risk and is cost effective. It is also consistent with the RAOs of the OU 5-12 ROD (DOE-ID 2000), is compliant with ARARs, and satisfies the DOE goal of reducing the "risk footprint," consolidating wastes at ICDF, and reducing surveillance and maintenance costs on legacy buildings and structures. Figure 8-1 is a conceptual end state depiction of the PBF area at the completion of Alternative 3.

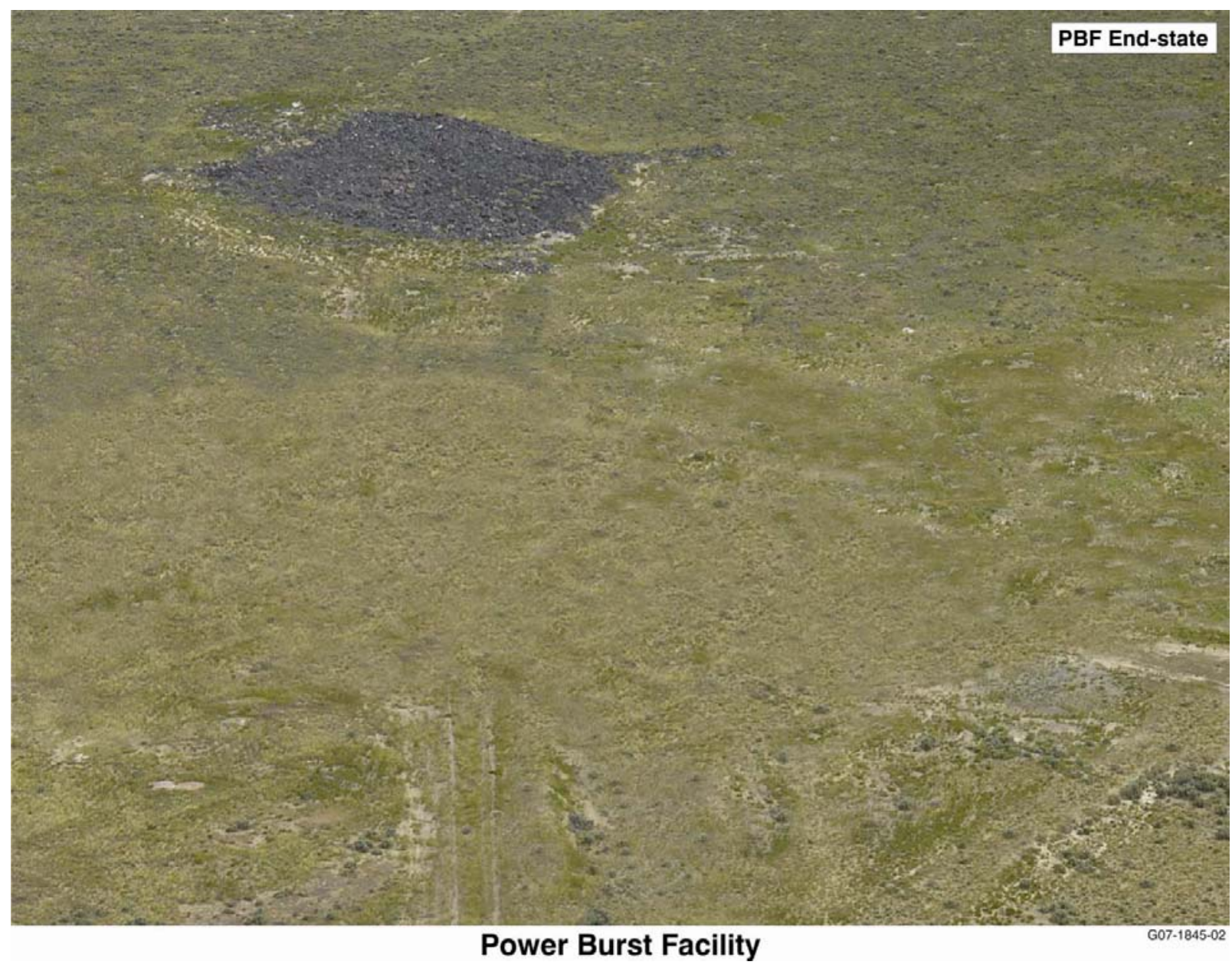

Figure 8-1. Conceptual end state under Alternative 3 for the PBF. 


\subsection{Compliance with Environmental Regulations}

Section 121 of CERCLA (42 USC $\S 9621$ ) requires the responsible CERCLA implementing agency to ensure that the substantive standards of HWMA/RCRA and other applicable laws will be incorporated into the federal agency's design and operation of its long-term remedial actions and into its more immediate removal actions. DOE-ID is the implementing agency for this NTCRA. Both the DEQ and the EPA concur that a NTCRA is warranted to protect human health and the environment. Through the NTCRA process, the risks presented in this document will be mitigated in a timely manner.

Table 8-1 lists the proposed ARARs that have been identified for this removal action. These ARARs are a compilation and expansion of the ARARs identified in the ROD (DOE-ID 2000). The ARARs list is based on several key assumptions:

- Any residual contamination left in place will meet the remedial action objectives established in the OU 5-12 ROD (DOE-ID 2000).

- $\quad$ The majority of lead shielding will be removed from PBF prior to initiation of this NTCRA through other regulatory activities intended to place the facility in an environmentally safe condition. However, some lead such as difficult to remove lead incidental to demolition such as lead enclosed or encapsulated in building structural material, may remain in place following these activities This will require management under the scope of the NTCRA as CERCLA waste. In addition, some incidental lead, such as small amounts of lead encapsulated in debris, may be managed under the scope of the NTCRA as CERCLA waste and be disposed of in the ICDF according to the WAC. Removed lead that cannot be recycled or reclaimed shall be declared a hazardous waste or mixed low-level waste, managed in accordance with the substantive requirements of the HWMA/RCRA, and will be disposed of at an off-Site disposal facility in accordance with the disposal facility WAC.

- $\quad$ Management of CERCLA waste generated during the removal action would be subject to meeting the ICDF WAC (DOE-ID 2005).

- If decontamination liquids are generated, they will be disposed of at the ICDF evaporation ponds in accordance with the approved WAC. Small amounts of decontamination liquid may be solidified with absorbent and be disposed of in the disposal cells at ICDF.

- $\quad$ Debris generated during removal of the vessel might have paint that contains PCBs. If encountered, such waste may trigger substantive requirements of the TSCA (15 USC $\S 2601$ et seq.). Lead-contaminated paint also may be removed during recovery of the shielding lead, which would be subject to the substantive requirements of RCRA hazardous waste regulations. Nonhazardous low-level waste would be disposed of at the ICDF. Waste that can be demonstrated to be nonhazardous and contain no added radiological constituents is eligible for disposal as solid waste at the Central Facilities Area Landfill Complex. The PCB-containing light ballasts are planned for removal from the building prior to this removal action with disposal off Site at an approved disposal facility. 


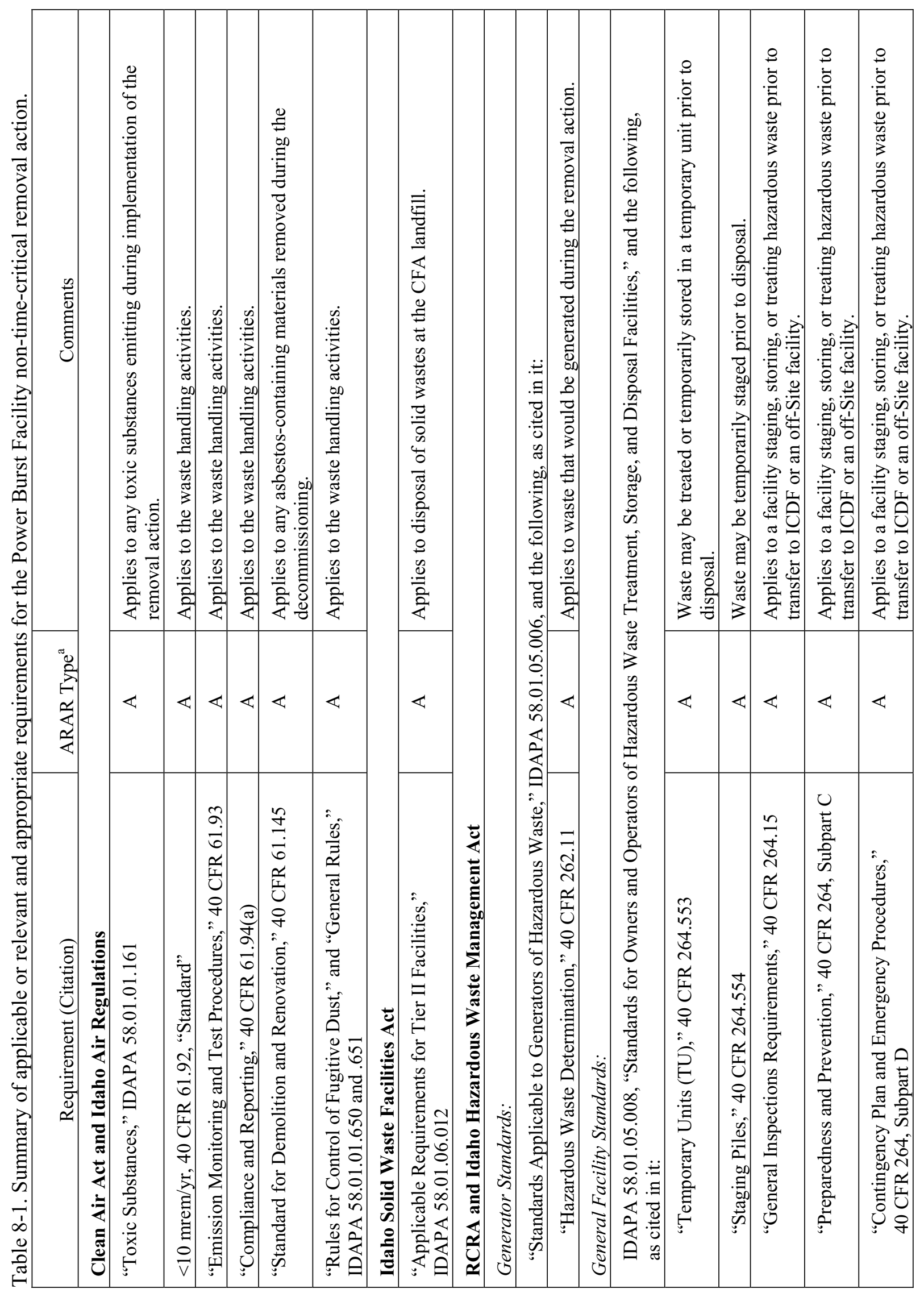




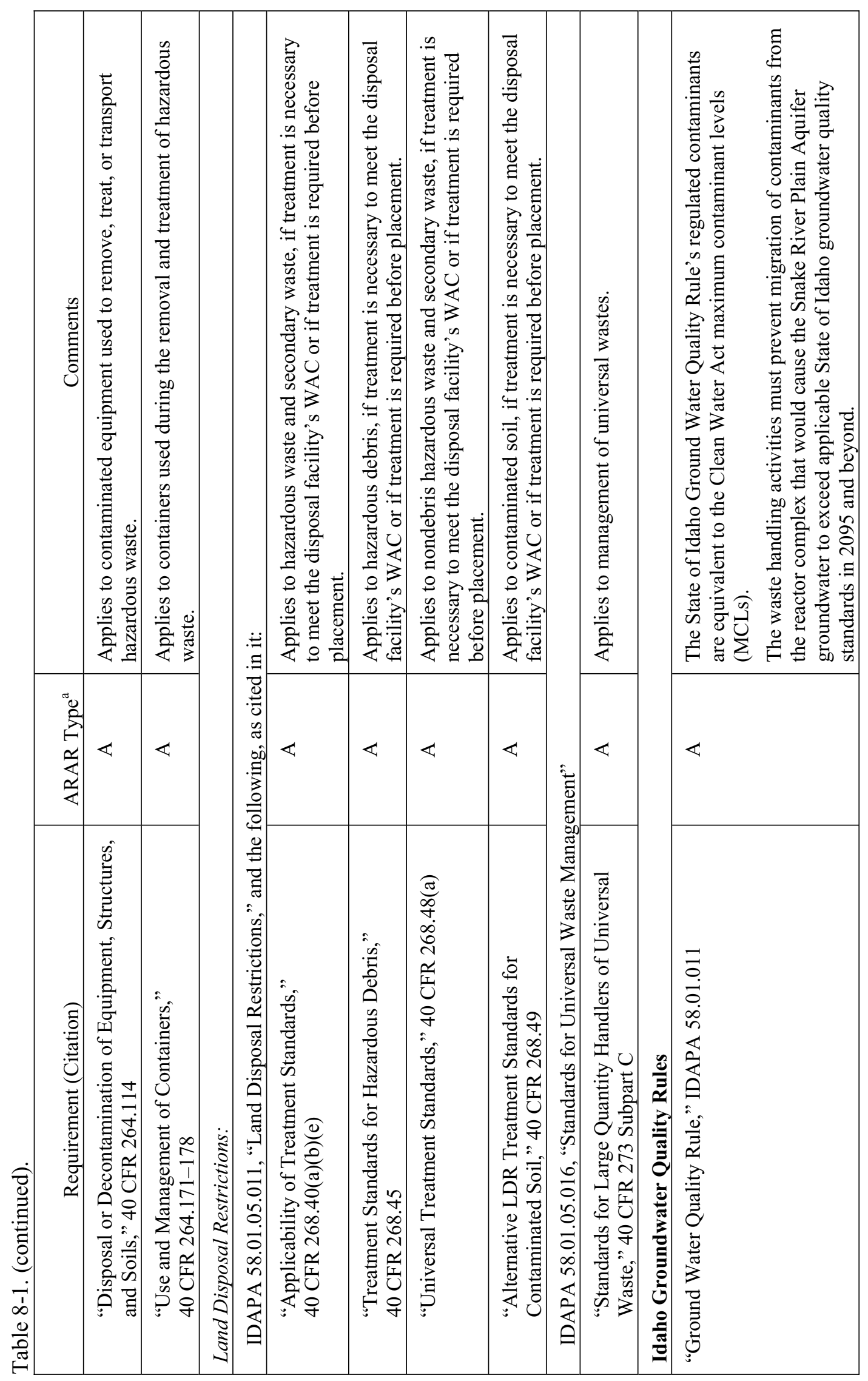




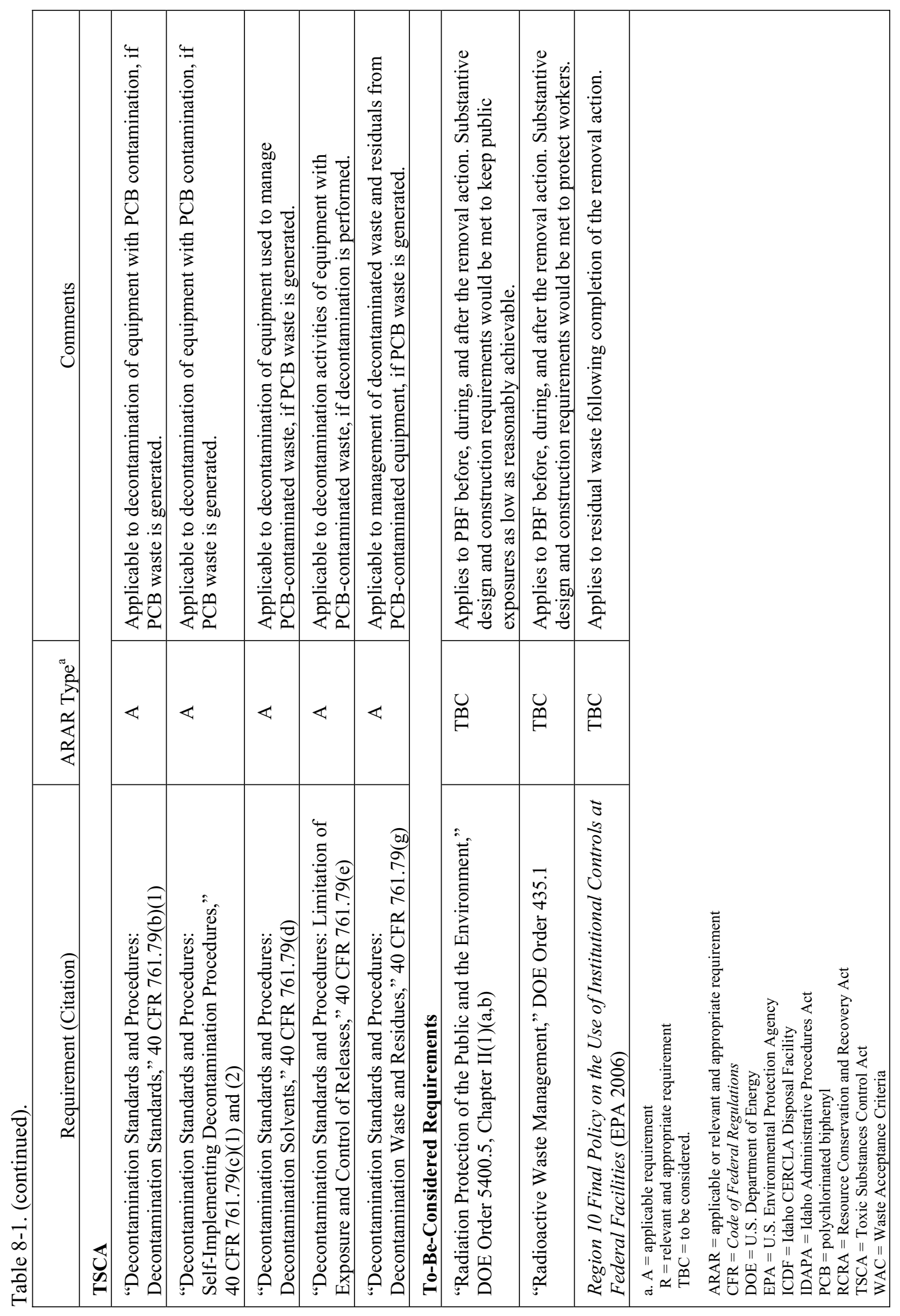


- Asbestos-containing material, which is both friable and nonfriable, may be encountered incidental to performance of the NTCRA. Friable or regulated asbestos-containing material is subject to specific asbestos regulations and would be acceptable for disposal at ICDF and/or, if not radiologically contaminated, at the Central Facilities Area Asbestos Landfill. Regulated asbestos will be removed and disposed of as required by 40 CFR 61.150, "Standard for Waste Disposal for Manufacturing, Fabricating, Demolition, Renovation, and Spraying Operations." Undisturbed asbestos or asbestos found in high-radiation, high-contamination, and/or inaccessible locations greater than $10 \mathrm{ft}$ below the ground surface may be left in place.

- Mercury located in mercury fluorescent lamps is planned for removal prior to this removal action under other regulatory activities intended to place the facility in an environmentally safe condition, as would the mercury-containing electrical switches and lights. No mercury is expected to be present in the building substructure at the start of the removal action.

\subsection{Cultural Resources}

Section 106 of the National Historic Preservation Act of 1966 (NHPA) (16 USC $\S 470$ et seq.), as amended, requires agencies to consider the impact of undertakings on properties listed or eligible for listing in the National Register of Historic Places and to consult with the Idaho State Historic Preservation Officer and other interested parties when impacts are likely. It also requires federal agencies to invite the Advisory Council on Historic Preservation to participate in consultation when impacts may be adverse. The NHPA Section 106 process has been tailored to meet the unique needs of the INL Site. Section 110 of the NHPA directs federal agencies to establish programs to find, evaluate, and nominate eligible properties to the National Register of Historic Places, including previously unidentified historic properties that may be discovered during the implementation of a project (36 CFR 800). In addition, the Archaeological Resources Protection Act of 1979 (16 USC $\S 470 \mathrm{aa}-470 \mathrm{~mm}$ ), as amended, provides for the protection and management of archaeological resources on federal lands. Procedures and strategies to tailor these requirements to the unique needs of the INL Site are described in the INL Cultural Resource Management Plan (CRMP) (DOE-ID 2004). The INL CRMP is implemented through a Programmatic Agreement between DOE-ID, the Idaho State Historic Preservation Officer, and the Advisory Council on Historic Preservation.

Per the INL CRMP, PER-620 is a Category 1 historic property, eligible for nomination to the National Register of Historic Places. However, DOE-ID has made the decision to proceed with demolition of this reactor building subject to the outcome of this EE/CA. To mitigate the adverse impacts caused by such an action, DOE-ID - through measures outlined in the CRMP, and a Memorandum of Agreement between DOE-ID and the Idaho State Historic Preservation Office - agreed to the preservation of PBF's history through the completion of a Historic American Engineering Record (HAER) report. HAER No. ID-33-F, Power Burst Facility and SPERT I Historic American Engineering Record, (ICP 2005) was completed in 2005 and approved by the National Park Service. It will ultimately be accessioned into the Library of Congress' permanent collections. No further cultural resource mitigation is needed for PBF-620.

DOE was required to review as guidance the most current United States Fish and Wildlife Service list for threatened and endangered plant and animal species. DOE-ID determined that none of the alternatives would impact any threatened and endangered species, and also determined that formal consultation with the United States Fish and Wildlife Service was not required for this action. 


\subsection{Compliance with Disposal Facility Waste Acceptance Criteria}

\subsubsection{ICDF Waste Acceptance Criteria}

ICDF is an on-Site disposal facility that accepts CERCLA waste generated at the INL. The PBF vessel meets the WAC for disposal at ICDF. Grout will be added to stabilize the vessel internals for shipment and reduce void spaces to prevent subsidence in the disposal cell.

\subsubsection{Achieving Removal Action Objectives}

The recommended alternative meets the proposed removal action objectives regarding long-term risk and is cost effective. Alternative 3 is also consistent with the RAOs of the OU 5-12 ROD (DOE-ID 2000), is compliant with ARARs, and satisfies the DOE goal of reducing the "risk footprint" by consolidating wastes at ICDF and reducing surveillance and maintenance costs on legacy buildings and structures. 


\section{REFERENCES}

36 CFR 800, 2004, "Protection of Historic Properties," Code of Federal Regulations, Office of the Federal Register, August 2004.

40 CFR 61, 2006, "National Emission Standards for Hazardous Air Pollutants," Code of Federal Regulations, Office of the Federal Register, July 2006.

40 CFR 61.92, 2006, "Standard," Code of Federal Regulations, Office of the Federal Register, July 2006.

40 CFR 61.93, 2006, "Emission Monitoring and Test Procedures," Code of Federal Regulations, Office of the Federal Register, July 2006.

40 CFR 61.94, 2006, "Compliance and Reporting," Code of Federal Regulations, Office of the Federal Register, July 2006.

40 CFR 61.145, 2006, "Standard for Demolition and Renovation," Code of Federal Regulations, Office of the Federal Register, July 2006.

40 CFR 61.150, 2006, "Standard for Waste Disposal for Manufacturing, Fabricating, Demolition, Renovation, and Spraying Operations," Code of Federal Regulations, Office of the Federal Register, July 2006.

40 CFR 141, 2006, "National Primary Drinking Water Regulations," Code of Federal Regulations, Office of the Federal Register, July 1, 2006.

49 CFR 173, 2006, "Shippers-General Requirements for Shipments and Packagings," Code of Federal Regulations, Office of the Federal Register, June 2006.

40 CFR 261, Appendix VIII, 2006, "Hazardous Constituents," Code of Federal Regulations, Office of the Federal Register, July 2006.

40 CFR 262.11, 2006, "Hazardous Waste Determination," Code of Federal Regulations, Office of the Federal Register, July 2006.

40 CFR 264.15, 2006, "General Inspection Requirements," Code of Federal Regulations, Office of the Federal Register, July 2006.

40 CFR 264.114, 2006, "Disposal or Decontamination of Equipment, Structures and Soils," Code of Federal Regulations, Office of the Federal Register, July 2006.

40 CFR 264.171, 2006, "Condition of Containers," Code of Federal Regulations, Office of the Federal Register, July 2006.

40 CFR 264.172, 2006, "Compatibility of Waste with Containers," Code of Federal Regulations, Office of the Federal Register, July 2006.

40 CFR 264.173, 2006, "Management of Containers," Code of Federal Regulations, Office of the Federal Register, July 2006.

40 CFR 264.174, 2006, "Inspections," Code of Federal Regulations, Office of the Federal Register, July 2006. 
40 CFR 264.175, 2006, “Containment,” Code of Federal Regulations, Office of the Federal Register, July 2006.

40 CFR 264.176, 2006, "Special Requirements for Ignitable or Reactive Waste," Code of Federal Regulations, Office of the Federal Register, July 2006.

40 CFR 264.177, 2006, "Special Requirements for Incompatible Wastes," Code of Federal Regulations, Office of the Federal Register, July 2006.

40 CFR 264.178, 2006, "Closure," Code of Federal Regulations, Office of the Federal Register, July 2006.

40 CFR 264.553, 2006, “Temporary Units (TU)," Code of Federal Regulations, Office of the Federal Register, July 2006.

40 CFR 264.554, 2006, "Staging Piles," Code of Federal Regulations, Office of the Federal Register, July 2006.

40 CFR 264, Subpart C, 2006, "Preparedness and Prevention," Code of Federal Regulations, Office of the Federal Register, July 2006.

40 CFR 264, Subpart D, 2006, "Contingency Plan and Emergency Procedures," Code of Federal Regulations, Office of the Federal Register, July 2006.

40 CFR 268.40, 2006, “Applicability of Treatment Standards," Code of Federal Regulations, Office of the Federal Register, July 2006.

40 CFR 268.45, 2006, "Treatment Standards for Hazardous Debris," Code of Federal Regulations, Office of the Federal Register, July 2006.

40 CFR 268.48, 2006, "Universal Treatment Standards," Code of Federal Regulations, Office of the Federal Register, July 2006.

40 CFR 268.49, 2006, “Alternative LDR Treatment Standards for Contaminated Soil,” Code of Federal Regulations, Office of the Federal Register, July 2006.

40 CFR 273, Subpart C, 2006, "Standards for Large Quantity Handlers of Universal Waste," Code of Federal Regulations, Office of the Federal Register, July 2006.

40 CFR 300, 2006, "National Oil and Hazardous Substances Pollution Contingency Plan," Code of Federal Regulations, Office of the Federal Register, August 2006.

40 CFR 300.415, 2006, "Removal Action," Code of Federal Regulations, Office of the Federal Register, August 2006.

40 CFR 761.79, 2006, "Decontamination Standards and Procedures," Code of Federal Regulations, Office of the Federal Register, June 2006.

15 USC $\S 2601$ et seq., 1976, “The Toxic Substances Control Act (TSCA) of 1976," United States Code, January 1, 1977.

16 USC § 470 et seq., 1966, "National Historic Preservation Act," United States Code, October 15, 1966. 
16 USC § 470aa-470mm, 2002, “Archaeological Resources Protection Act,” United States Code, January 22, 2002.

42 USC § 300f et seq., "Safe Drinking Water Act,” United States Code, December 1974.

42 USC § 6901 et seq., 1976, "Resource Conservation and Recovery Act (Solid Waste Disposal Act)," United States Code, October 21, 1976.

42 USC § 7401 et seq., 1970, “Clean Air Act,” United States Code, December 31, 1970 (as amended).

42 USC § 9601 et seq., 1980, "Comprehensive Environmental Response, Compensation and Liability Act of 1980 (CERCLA/Superfund)," United States Code, December 11, 1980.

42 USC § 9621, 1998, “Cleanup Standards,” United States Code, January 26, 1998.

DEQ, 2000, B. R. Monson, DEQ, to D. N. Rasch, DOE-ID, Enclosure: “Consent Order," Idaho Code § 39-4413, June 14, 2000.

DOE, 1999, Final Hanford Comprehensive Land-Use Plan Environmental Impact Statement, Hanford Site, Richland, Washington, DOE/EIS-0222-F, U.S. Department of Energy, October 1999.

DOE and EPA, 1995, Policy on Decommissioning of Department of Energy Facilities Under the Comprehensive Environmental Response, Compensation, and Liability Act (CERCLA), KLF-211-95, Rev. 0, U.S. Department of Energy, Washington, D.C., and U.S. Environmental Protection Agency, Washington, D.C., May 22, 1995.

DOE O 435.1, 2001, Change 1, "Radioactive Waste Management," U.S. Department of Energy, August 28, 2001.

DOE O 5400.5, 1993, Change 2, "Radiation Protection of the Public and the Environment," U.S. Department of Energy, January 7, 1993.

DOE-ID, 1991, Federal Facility Agreement and Consent Order for the Idaho National Engineering Laboratory, Administrative Docket No. 1088-06-120, U.S. Department of Energy Idaho Operations Office; U.S. Environmental Protection Agency, Region 10; Idaho Department of Health and Welfare, December 9, 1991.

DOE-ID, 1992, Record of Decision, Test Reactor Area Perched Water System, Operable Unit 2-12, Idaho National Engineering and Environmental Laboratory, Idaho Falls, Idaho, Document ID 5230, Rev. 0, U.S. Department of Energy Idaho Operations Office; U.S. Environmental Protection Agency, Region 10; Idaho Department of Health and Welfare, December 1992.

DOE-ID, 1994, Track 2 Sites: Guidance for Assessing Low Probability Hazard Sites at the INEL, DOE/ID-10389, Rev. 6, U.S. Department of Energy Idaho Operations Office, January 1994.

DOE-ID, 1999, Final Record of Decision, Idaho Nuclear Technology and Engineering Center, Operable Unit 3-13, DOE/ID-10660, Rev. 0, U.S. Department of Energy Idaho Operations Office, October 1999.

DOE-ID, 2000, Record of Decision, Power Burst Facility and Auxiliary Reactor Area; Operable Unit 5-12, DOE/ID-10700, January 2000. 
DOE-ID, 2001, Comprehensive Remedial Investigation/Feasibility Study for Waste Area Groups 6 and 10 Operable Unit 10-04, DOE/ID-10807, U.S. Department of Energy Idaho Operations Office, July 1, 2001. DOE-ID, 2003, Performance Assessment for the INEEL CERCLA Disposal Facility Landfill, DOE/ID-10978, Rev. 0, U.S. Department of Energy Idaho Operations Office, August 2003.

DOE-ID, 2004, Idaho National Engineering and Environmental Laboratory Cultural Resource Management Plan, DOE/ID-10997, Rev. 0, U.S. Department of Energy Idaho Operations Office, August 2004.

DOE-ID, 2005, ICDF Complex Waste Acceptance Criteria, Rev. 2, DOE/ID-10881, U.S. Department of Energy Idaho Operations Office, July 2005.

DOE-ID, 2006, Action Memorandum for General Decommissioning Activities Under the Idaho Cleanup Project, DOE/ID-11293, U.S. Department of Energy Idaho Operations Office, October 2006.

DOE/NE-ID, 2004, Engineering Evaluation/Cost Analysis for the Phase 1 of the Decommissioning for the Power Burst Facility Reactor Building (PER-620), DOE/NE-ID-11196, U.S. Department of Energy Office of Nuclear Energy, Science, and Technology, Idaho Operations Office, December 2004.

DOE/NE-ID, 2005, Action Memorandum for Phase 1 of the Decommissioning for the Power Burst Facility Reactor Building (PER-620), DOE/NE-ID-11213, U.S. Department of Energy Office of Nuclear Energy, Science, and Technology, Idaho Operations Office, February 2005.

EDF-4869, 2004, “Groundwater Pathway Risk Assessment for the PBF Closure,” Idaho National Engineering and Environmental Laboratory, July 2004.

EDF-7000, 2006, “Power Burst Facility (PBF) Below and Above Grade Source Terms,” Rev. 0, Idaho Cleanup Project, September 28, 2006.

EDF-7433, 2007, “Streamlined Risk Assessment for D\&D of the PBF Reactor Facility,” Rev. 0, Idaho Cleanup Project, March 2007.

EDF-7618, 2007, "Groundwater Pathway Risk Assessment for the PBF Closure-2007 Update,” Rev. 0, Idaho Cleanup Project, January 18, 2007.EPA, 1993, Guidance on Conducting Non-Time Critical Removal Actions Under CERCLA, EPA/540-R-93-057, U.S. Environmental Protection Agency, August 1993.

EPA, 1996, Soil Screening Guidance: User's Guide, Second Edition, EPA/540/R-96/018, U.S. Environmental Protection Agency, July 1996.

EPA, 2000a, Soil Screening Guidance for Radionuclides: User's Guide, EPA/540-R-00-007, U.S. Environmental Protection Agency, October 2000.

EPA, 2000b, A Guide to Developing and Documenting Cost Estimates During the Feasibility Study, EPA/540-R-00-002, U.S. Environmental Protection Agency, July 2000.

EPA, 2006, Region 10 Final Policy on the Use of Institutional Controls at Federal Facilities, U.S. Environmental Protection Agency, May 2006. 
Holdren, K. J., C. M. Hiaring, D. E. Burns, N. L. Hampton, B. J. Broomfield, E. R. Neher, R. L. Van Horn, I. E., Stepan, R. P. Wells, R. L. Chambers, L. Schmeising, and R. Henry, 1999, Waste Area Group 5 Operable Unit 5-12 Comprehensive Remedial Investigation/Feasibility Study, DOE/ID-10607, Rev. 0, U.S. Department of Energy Idaho Operations Office, January 1999.

ICP, 2005, INEEL Power Burst Facility and SPERT I Historic American Engineering Record, ICP/EXT-05-00768, Idaho Cleanup Project.

Idaho Code $§ 39-4401$ et seq., 1983, "Hazardous Waste Management Act of 1983," State of Idaho, Boise, Idaho.

IDAPA 58.01.01.161, 1995, “Toxic Substances,” Idaho Administrative Procedures Act, Idaho Department of Environmental Quality, June 30, 1995.

IDAPA 58.01.01.650, 1994, "Rules for Control of Fugitive Dust," Idaho Administrative Procedures Act, Idaho Department of Environmental Quality, May 1, 1994.

IDAPA 58.01.01.651, 1994, "General Rules," Idaho Administrative Procedures Act, Idaho Department of Environmental Quality, May 1, 1994.

IDAPA 58.01.05.006, 2006, "Standards Applicable to Generators of Hazardous Waste," Idaho Administrative Procedures Act, Idaho Department of Environmental Quality, April 11, 2006.

IDAPA 58.01.05.008, 2006, "Standards for Owners and Operators of Hazardous Waste Treatment, Storage, and Disposal Facilities," Idaho Administrative Procedures Act, Idaho Department of Environmental Quality, April 11, 2006.

IDAPA 58.01.05.011, 2006, "Land Disposal Restrictions," Idaho Administrative Procedures Act, Idaho Department of Environmental Quality, April 11, 2006.

IDAPA 58.01.05.016, 2006, "Standards for Universal Waste Management," Idaho Administrative Procedures Act, Idaho Department of Environmental Quality, April 11, 2006.

IDAPA 58.01.06.012, 2003, “Applicable Requirements for Tier II Facilities," Idaho Administrative Procedures Act, Idaho Department of Environmental Quality, April 3, 2003.

IDAPA 58.01.011, 1997, “Ground Water Quality Rule,” Idaho Administrative Procedures Act, Idaho Department of Environmental Quality, March 20, 1997.

NCRP, 1996, Screening Models for Releases of Radionuclides to Atmosphere, Surface Water, and Ground-Water, NCRP Report No. 123, National Council on Radiation Protection.

Public Law 99-499, 1986, "Superfund Amendments and Reauthorization Act of 1986 (SARA)," 100 Statutes 1728, Public Law, October 17, 1986.

Rood, A. S., 2003, GWSCREEN: A Semi-Analytical Model for Assessment of the Groundwater Pathway from Surface or Buried Contamination: Theory and User's Manual Version 2.5, INEEL/EXT-98-00750, Rev. 1b, Idaho National Engineering and Environmental Laboratory April 2003. 
VanHorn, R., N. Hampton, and R. Morris, 1995, Guidance Manual for Conducting Screening-Level Ecological Risk Assessments at the INEL, EXT-1995-000821, Idaho National Engineering Laboratory, April 12, 1995.

Van Horn, Robin and Sherri Stacey, 2004, Risk-Based Screening and Assessment Approach for Waste Area Group 1 Soils, INEEL/ EXT-03-00540, Idaho National Engineering and Environmental Laboratory, May 19, 2004. 
Appendix A

\section{Total Above and Below Ground Level Radionuclides and Activity Value}


A-2 


\begin{tabular}{|c|c|c|c|c|c|c|c|c|c|c|c|c|c|c|c|c|c|c|c|c|c|c|c|c|c|c|c|c|c|}
\hline 超 & 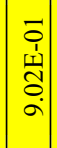 & 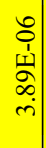 & $\begin{array}{c}0 \\
0 \\
1 \\
0 \\
\infty \\
\sigma \\
\sigma\end{array}$ & 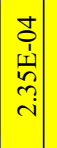 & 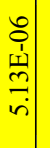 & $\begin{array}{l}0 \\
0 \\
1 \\
\vdots \\
0 \\
0 \\
0\end{array}$ & 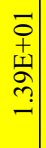 & 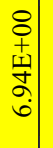 & 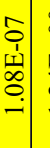 & 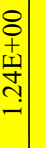 & 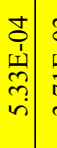 & 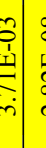 & 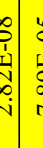 & 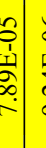 & 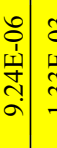 & 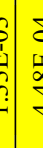 & 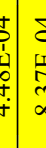 & 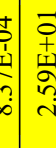 & 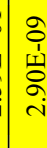 & $\begin{array}{c}0 \\
0 \\
0 \\
1 \\
\vdots \\
-1 \\
-1\end{array}$ & 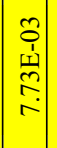 & 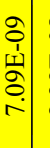 & 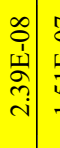 & 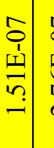 & 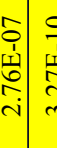 & 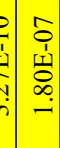 & 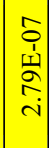 & & 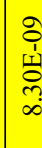 \\
\hline 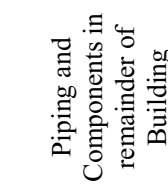 & & & & & & & & & & & & & & & & & & 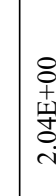 & & & & & & & & & & & \\
\hline 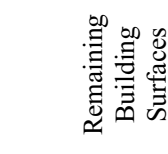 & & & & & & & & & & & & & & & & & & $\begin{array}{l}\stackrel{9}{+} \\
\vdots \\
\vdots \\
+\end{array}$ & & & & & & & & & & & \\
\hline 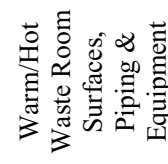 & & & & & & & & & & & & & & & & & & $\begin{array}{l}5 \\
\text { ì } \\
\text { ind } \\
\text { in }\end{array}$ & & & & & & & & & & & \\
\hline 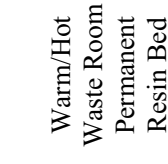 & & 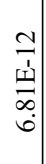 & $\mid \begin{array}{c}\infty \\
0 \\
1 \\
\sim \\
\cdots \\
\end{array}$ & 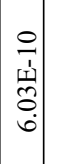 & \begin{tabular}{l|}
0 \\
\multicolumn{1}{|c}{} \\
1 \\
\\
$i$
\end{tabular} & 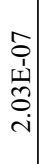 & 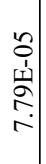 & 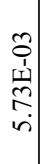 & $\begin{array}{c}5 \\
\vdots \\
1 \\
\vdots \\
\vdots \\
-1\end{array}$ & 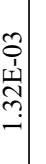 & 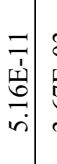 & 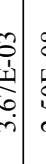 & 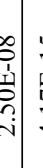 & 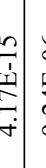 & 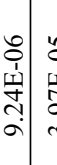 & 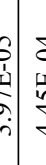 & 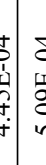 & $\begin{array}{c}\vdots \\
\vdots \\
\vdots \\
\vdots \\
\vdots\end{array}$ & 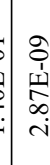 & 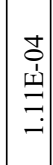 & $\mid \begin{array}{l}2 \\
0 \\
1 \\
2 \\
2 \\
-1\end{array}$ & $\begin{array}{l}\text { gे } \\
1 \\
\text { Ij } \\
\text { oे } \\
\dot{+}\end{array}$ & 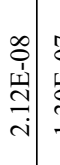 & 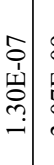 & 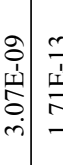 & 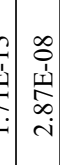 & 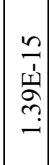 & 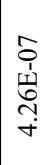 & $\begin{array}{l}8 \\
\text { iे } \\
\text { İ } \\
\text { m. }\end{array}$ \\
\hline 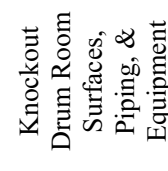 & & & & & & & & & & & & & & & & & & 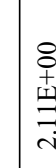 & & & & & & & & & & & \\
\hline 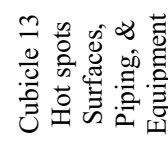 & & & & & & & & & & & & & & & & & & 辛 & & & & & & & & & & & \\
\hline 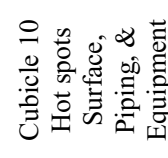 & & & & & & & & & & & & & & & & & & 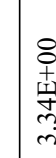 & & & & & & & & & & & \\
\hline 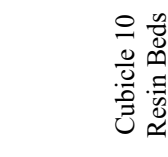 & & 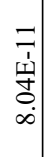 & & & & & & & & 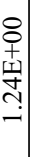 & 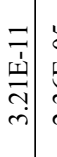 & & 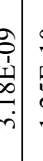 & 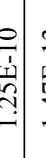 & 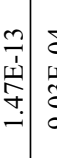 & 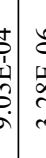 & 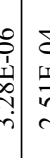 & 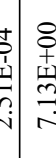 & $\begin{array}{l}\overline{7} \\
\stackrel{7}{N} \\
\\
\end{array}$ & 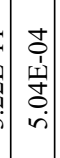 & $\mid \begin{array}{c}0 \\
0 \\
\vdots \\
\vdots \\
0 \\
0 \\
0\end{array}$ & $\begin{array}{l}o \\
\text { ì } \\
\text { in } \\
\text { ì }\end{array}$ & 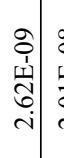 & 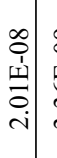 & 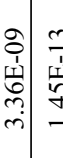 & 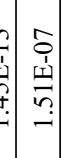 & $\begin{array}{l}0 \\
0 \\
1 \\
0 \\
0 \\
\infty \\
\infty\end{array}$ & $\begin{array}{l}\infty \\
0 \\
1 \\
1 \\
\vdots \\
-2 \\
-1\end{array}$ & 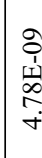 \\
\hline 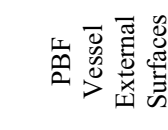 & & & & & & & & & & & & & & & & & & 量 & & & & & & & & & & & \\
\hline 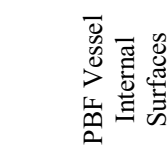 & & 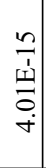 & \begin{tabular}{l}
7 \\
\multirow{0}{0}{} \\
$\stackrel{2}{2}$ \\
-1
\end{tabular} & 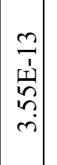 & 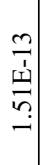 & 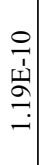 & $\begin{array}{c}0 \\
0 \\
1 \\
\vdots \\
\vdots \\
+\end{array}$ & 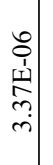 & \begin{tabular}{l|l}
7 \\
\multirow{1}{n}{} \\
\\
|
\end{tabular} & 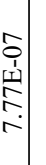 & 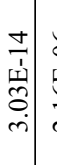 & 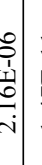 & 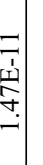 & 先 & 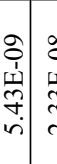 & 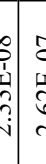 & 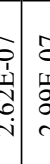 & 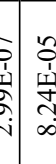 & a & $\begin{array}{l}0 \\
0 \\
0 \\
1 \\
n \\
n \\
0 \\
0\end{array}$ & $\mid \begin{array}{c}0 \\
0 \\
1 \\
\\
o \\
r\end{array}$ & 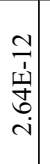 & 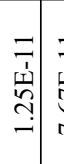 & 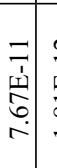 & 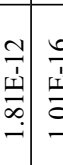 & 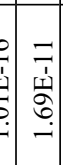 & 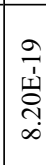 & $\begin{array}{c}\frac{9}{4} \\
\frac{1}{n} \\
\\
i\end{array}$ & $\stackrel{?}{\stackrel{2}{2}}$ \\
\hline 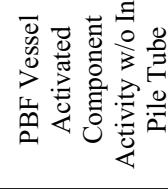 & $\begin{array}{c}\overrightarrow{0} \\
0 \\
1 \\
\vdots \\
\vdots \\
\vdots \\
0\end{array}$ & 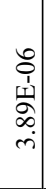 & $\mid \begin{array}{c}0 \\
0 \\
1 \\
\infty \\
\infty \\
\alpha \\
\sigma\end{array}$ & 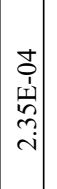 & \begin{tabular}{l}
0 \\
$\vdots$ \\
\multicolumn{1}{|c|}{} \\
\\
$\vec{n}$
\end{tabular} & \begin{tabular}{l}
\multicolumn{2}{c}{} \\
$\hat{1}$ \\
\\
0 \\
0
\end{tabular} & 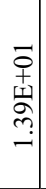 & 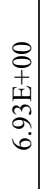 & 产 & | & 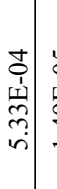 & $\begin{array}{l}6 \\
\vdots \\
\vdots \\
y \\
y\end{array}$ & $\begin{array}{l}7 \\
\frac{1}{2} \\
\frac{1}{2}\end{array}$ & 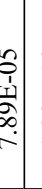 & 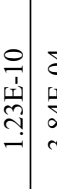 & 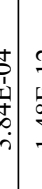 & 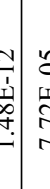 & 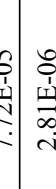 & $\frac{\frac{m}{7}}{\frac{5}{a}}$ & 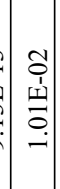 & $\mid \begin{array}{c}0 \\
0 \\
1 \\
1 \\
2 \\
\infty \\
\infty\end{array}$ & 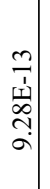 & & $\begin{array}{l}0 \\
\cdots \\
n \\
n \\
\sim \\
+\end{array}$ & 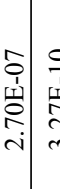 & 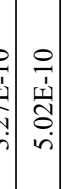 & 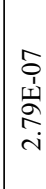 & & 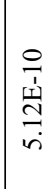 \\
\hline & $\stackrel{?}{ \pm}$ & $\vec{j}$ & \pm & 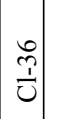 & 点 & 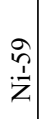 & إذ & $\begin{array}{l}\Omega \\
\vdots \\
z \\
z\end{array}$ & 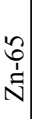 & 8 & $\begin{array}{l}\text { aे } \\
\text { zे }\end{array}$ & נ: & 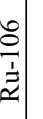 & 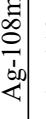 & 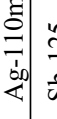 & $\begin{array}{l}8 \\
\vdots \\
b\end{array}$ & tे & 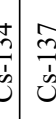 & $\frac{7}{d}$ & $\mid \begin{array}{l}\sqrt{2} \\
\frac{1}{ \pm}\end{array}$ & 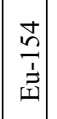 & $\vec{\sim}$ & $\begin{array}{l}\text { तै } \\
\stackrel{1}{a} \\
\approx\end{array}$ & \begin{tabular}{l} 
ते \\
\multirow{2}{4}{}
\end{tabular} & 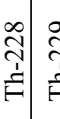 & 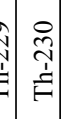 & $\begin{array}{l}\stackrel{\overbrace{}}{1} \\
\stackrel{I}{=}\end{array}$ & $\begin{array}{l}\overrightarrow{\widetilde{N}} \\
\tilde{d} \\
\tilde{c}\end{array}$ & తి \\
\hline
\end{tabular}




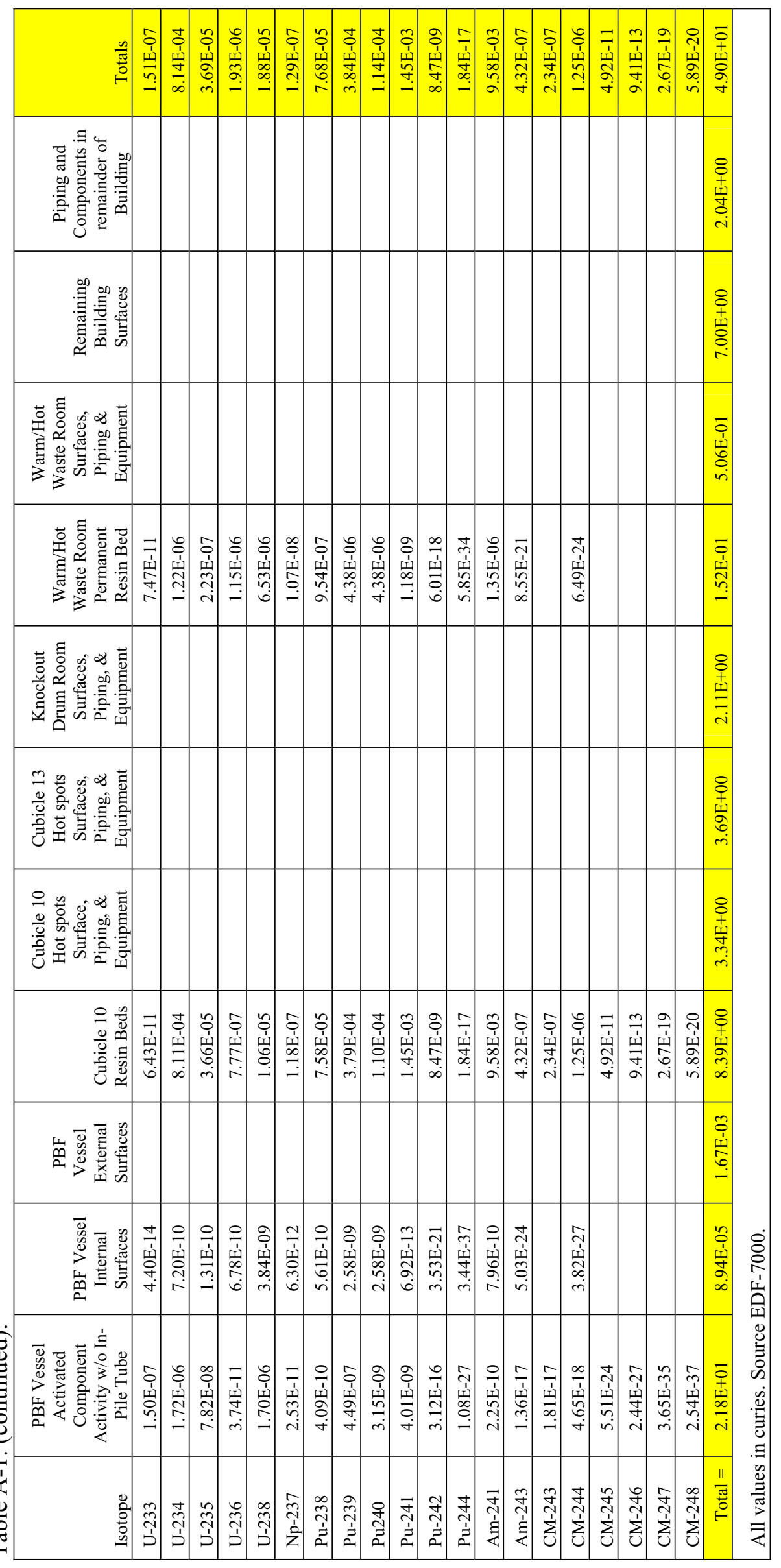


Appendix B

$0 \mathrm{ft}$ to $10 \mathrm{ft}$ Below Ground Level Radionuclides and Activity Value 
B-2 


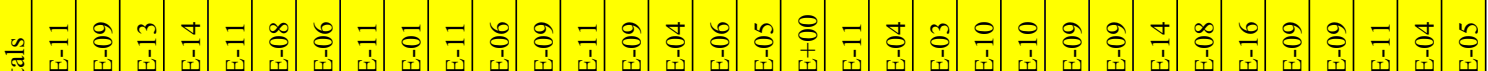

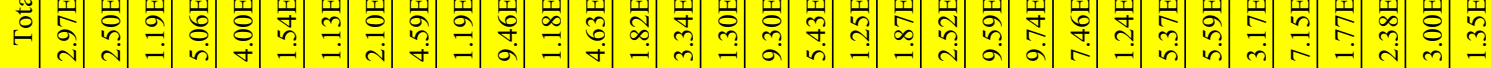

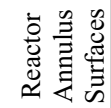

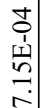

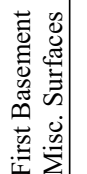

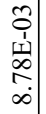

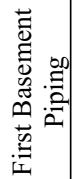

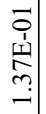

$\infty$

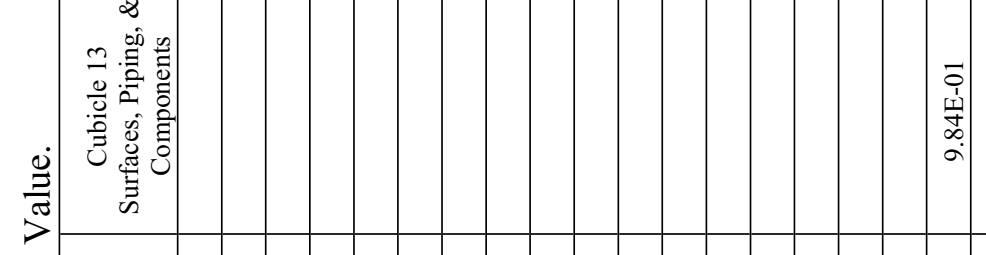

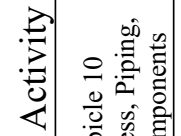

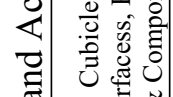

के $\overline{0}$

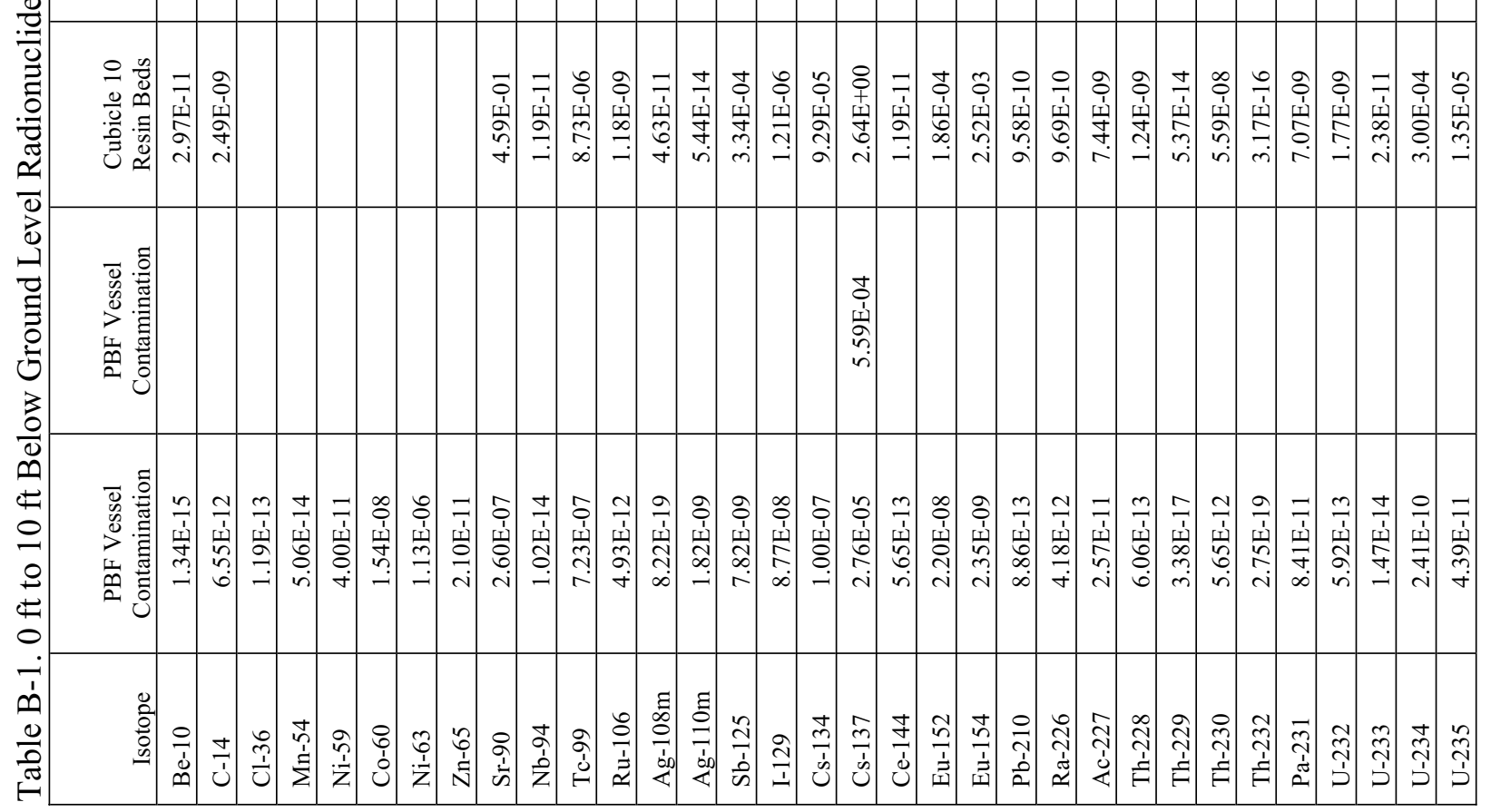




\begin{tabular}{|c|c|c|c|c|c|c|c|c|c|c|c|c|c|c|c|c|c|}
\hline & $\left|\begin{array}{c}0 \\
0 \\
0 \\
0 \\
\infty \\
i\end{array}\right|$ & 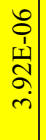 & 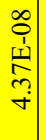 & $\begin{array}{l}n \\
0 \\
1 \\
0 \\
\infty \\
i \\
\end{array}$ & 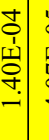 & $\begin{array}{l}2 \\
0 \\
\vdots \\
\\
0 \\
\dot{+} \\
\dot{+}\end{array}$ & 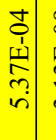 & 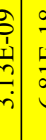 & 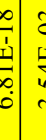 & 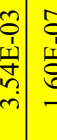 & 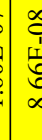 & 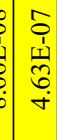 & 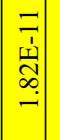 & 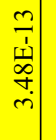 & 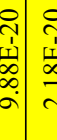 & 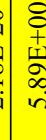 & \\
\hline 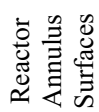 & & & & & & & & & & & & & & & & & \\
\hline 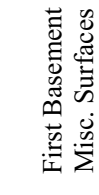 & & & & & & & & & & & & & & & & & \\
\hline 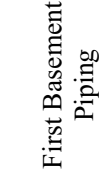 & & & & & & & & & & & & & & & & 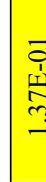 & \\
\hline 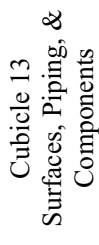 & & & & & & & & & & & & & & & & 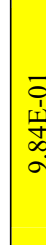 & \\
\hline 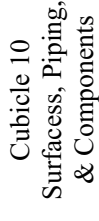 & & & & & & & & & & & & & & & & 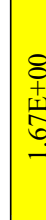 & \\
\hline 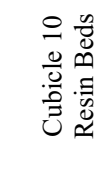 & $\mid$\begin{tabular}{c}
0 \\
0 \\
1 \\
\multicolumn{1}{c}{} \\
0 \\
$i$ \\
\end{tabular} & $\begin{array}{c}8 \\
\vdots \\
\vdots \\
\vdots \\
\\
\end{array}$ & 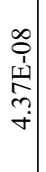 & 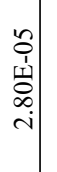 & 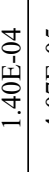 & $\begin{array}{l}n \\
0 \\
1 \\
\vdots \\
\vdots \\
\dot{+}\end{array}$ & 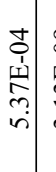 & 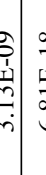 & 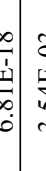 & 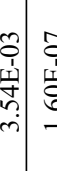 & 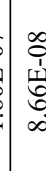 & 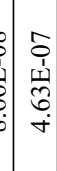 & 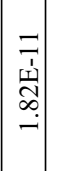 & 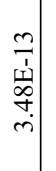 & 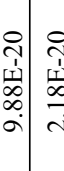 & 要 & \\
\hline 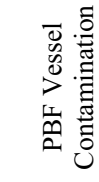 & & & & & & & & & & & & & & & & 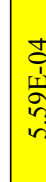 & 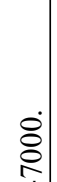 \\
\hline 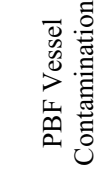 & 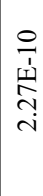 & . & 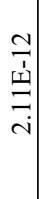 & $\begin{array}{l}0 \\
7 \\
1 \\
0 \\
0 \\
\infty \\
-1 \\
-1\end{array}$ & \begin{tabular}{l|l}
0 & \\
1 & \\
& \\
$\infty$ & \\
$\infty$ &
\end{tabular} & 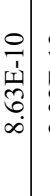 & 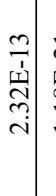 & 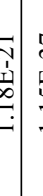 & 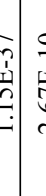 & 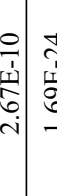 & 辛 & 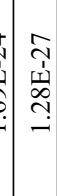 & 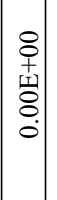 & $\begin{array}{l}0 \\
0 \\
+ \\
0 \\
0 \\
0\end{array}$ & 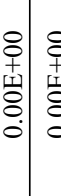 & 告 & 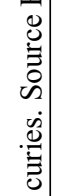 \\
\hline 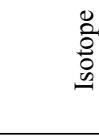 & త్రి & $\underset{\sim}{\infty}$ & $\left|\begin{array}{l}0 \\
\hat{n} \\
\vdots \\
0\end{array}\right|$ & 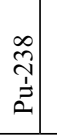 & I & $\stackrel{f}{3}$ & 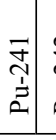 & $\begin{array}{c}\text { I⿱ } \\
\frac{1}{2} \\
\end{array}$ & 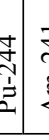 & 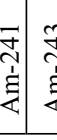 & 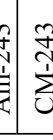 & 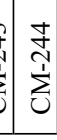 & 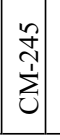 & \begin{tabular}{l}
0 \\
\multirow{1}{*}{} \\
\multirow{2}{1}{} \\
0
\end{tabular} & 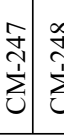 & \begin{tabular}{|l|l}
0 \\
$\vdots$
\end{tabular} & $\begin{array}{l}\bar{\pi} \\
\vec{\Xi} \\
\bar{Z}\end{array}$ \\
\hline
\end{tabular}




\section{Appendix C}

Above Ground Level Radionuclides and Activity 


$$
\text { C-2 }
$$


Table C-1. Above Ground Level Radionuclides and Activity.

\begin{tabular}{|c|c|c|c|c|c|c|}
\hline Nuclide & $\begin{array}{l}\text { Above Ground } \\
\text { Level } \\
\text { Reactor Internal } \\
\text { Contamination }\end{array}$ & $\begin{array}{l}\text { Above Ground } \\
\text { Level } \\
\text { Reactor External } \\
\text { Contamination }\end{array}$ & $\begin{array}{c}\text { Main Floor } \\
\text { Surface } \\
\text { Contamination }\end{array}$ & $\begin{array}{c}\text { Annulus } \\
\text { Surface } \\
\text { Contamination }\end{array}$ & $\begin{array}{l}\text { Above Ground } \\
\text { Level } \\
\text { Piping \& } \\
\text { Components }\end{array}$ & $\begin{array}{l}\text { Total } \\
(\mathrm{Ci})\end{array}$ \\
\hline $\mathrm{Be}-10$ & $2.89 \mathrm{E}-16$ & & & & & $2.89 \mathrm{E}-16$ \\
\hline C-14 & $1.41 \mathrm{E}-12$ & & & & & $1.41 \mathrm{E}-12$ \\
\hline $\mathrm{Cl}-36$ & $2.56 \mathrm{E}-14$ & & & & & $2.56 \mathrm{E}-14$ \\
\hline Mn-54 & $1.09 \mathrm{E}-14$ & & & & & $1.09 \mathrm{E}-14$ \\
\hline $\mathrm{Ni}-59$ & $8.61 \mathrm{E}-12$ & & & & & $8.61 \mathrm{E}-12$ \\
\hline Co-60 & $3.30 \mathrm{E}-09$ & & & & & $3.30 \mathrm{E}-09$ \\
\hline $\mathrm{Ni}-63$ & $2.43 \mathrm{E}-07$ & & & & & $2.43 \mathrm{E}-07$ \\
\hline $\mathrm{Zn}-65$ & $4.52 \mathrm{E}-12$ & & & & & $4.52 \mathrm{E}-12$ \\
\hline Sr-90 & $5.60 \mathrm{E}-08$ & & & & & $5.60 \mathrm{E}-08$ \\
\hline $\mathrm{Nb}-94$ & $2.19 \mathrm{E}-15$ & & & & & $2.19 \mathrm{E}-15$ \\
\hline Tc-99 & $1.55 \mathrm{E}-07$ & & & & & $1.55 \mathrm{E}-07$ \\
\hline Ru-106 & $1.06 \mathrm{E}-12$ & & & & & $1.06 \mathrm{E}-12$ \\
\hline Ag- $108 \mathrm{~m}$ & $1.77 \mathrm{E}-19$ & & & & & $1.77 \mathrm{E}-19$ \\
\hline Ag-110m & $3.92 \mathrm{E}-10$ & & & & & $3.92 \mathrm{E}-10$ \\
\hline Sb-125 & $1.68 \mathrm{E}-09$ & & & & & $1.68 \mathrm{E}-09$ \\
\hline I-129 & $1.88 \mathrm{E}-08$ & & & & & $1.88 \mathrm{E}-08$ \\
\hline Cs-134 & $2.16 \mathrm{E}-08$ & & & & & $2.16 \mathrm{E}-08$ \\
\hline Cs-137 & $5.94 \mathrm{E}-06$ & $1.49 \mathrm{E}-04$ & $4.98 \mathrm{E}+00$ & $1.28 \mathrm{E}-04$ & $1.36 \mathrm{E}-01$ & $5.11 \mathrm{E}+00$ \\
\hline Ce-144 & $1.21 \mathrm{E}-13$ & & & & & $1.21 \mathrm{E}-13$ \\
\hline Eu-152 & 4.72E-09 & & & & & 4.72E-09 \\
\hline Eu-154 & $5.06 \mathrm{E}-10$ & & & & & $5.06 \mathrm{E}-10$ \\
\hline $\mathrm{Pb}-210$ & $1.90 \mathrm{E}-13$ & & & & & $1.90 \mathrm{E}-13$ \\
\hline $\mathrm{Ra}-226$ & $9.00 \mathrm{E}-13$ & & & & & $9.00 \mathrm{E}-13$ \\
\hline Ac- 227 & $5.53 \mathrm{E}-12$ & & & & & $5.53 \mathrm{E}-12$ \\
\hline Th-228 & $1.30 \mathrm{E}-13$ & & & & & $1.30 \mathrm{E}-13$ \\
\hline Th-229 & 7.27E-18 & & & & & 7.27E-18 \\
\hline Th-230 & $1.21 \mathrm{E}-12$ & & & & & $1.21 \mathrm{E}-12$ \\
\hline Th-232 & $5.91 \mathrm{E}-20$ & & & & & $5.91 \mathrm{E}-20$ \\
\hline $\mathrm{Pa}-231$ & $1.81 \mathrm{E}-11$ & & & & & $1.81 \mathrm{E}-11$ \\
\hline U-232 & $1.27 \mathrm{E}-13$ & & & & & $1.27 \mathrm{E}-13$ \\
\hline U-233 & $3.17 \mathrm{E}-15$ & & & & & $3.17 \mathrm{E}-15$ \\
\hline U-234 & $5.19 \mathrm{E}-11$ & & & & & $5.19 \mathrm{E}-11$ \\
\hline U-235 & $9.44 \mathrm{E}-12$ & & & & & $9.44 \mathrm{E}-12$ \\
\hline U-236 & $4.89 \mathrm{E}-11$ & & & & & $4.89 \mathrm{E}-11$ \\
\hline U-238 & $2.77 \mathrm{E}-10$ & & & & & $2.77 \mathrm{E}-10$ \\
\hline Np-237 & $4.54 \mathrm{E}-13$ & & & & & $4.54 \mathrm{E}-13$ \\
\hline $\mathrm{Pu}-238$ & 4.04E-11 & & & & & $4.04 \mathrm{E}-11$ \\
\hline $\mathrm{Pu}-239$ & $1.86 \mathrm{E}-10$ & & & & & $1.86 \mathrm{E}-10$ \\
\hline $\mathrm{Pu}-240$ & $1.86 \mathrm{E}-10$ & & & & & $1.86 \mathrm{E}-10$ \\
\hline $\mathrm{Pu}-241$ & $4.98 \mathrm{E}-14$ & & & & & $4.98 \mathrm{E}-14$ \\
\hline $\mathrm{Pu}-242$ & $2.55 \mathrm{E}-22$ & & & & & $2.55 \mathrm{E}-22$ \\
\hline $\mathrm{Pu}-244$ & $2.48 \mathrm{E}-38$ & & & & & $2.48 \mathrm{E}-38$ \\
\hline Am-241 & $5.73 \mathrm{E}-11$ & & & & & $5.73 \mathrm{E}-11$ \\
\hline Am-243 & $3.62 \mathrm{E}-25$ & & & & & $3.62 \mathrm{E}-25$ \\
\hline \multirow{2}{*}{\multicolumn{5}{|c|}{ (1) }} & & $2.75 \mathrm{E}-28$ \\
\hline & & & & & $\operatorname{Total}(\mathrm{Ci})=$ & $5.11 \mathrm{E}+00$ \\
\hline
\end{tabular}


Appendix D

PBF Vessel Radionuclides and Activity by Component 
D-2 


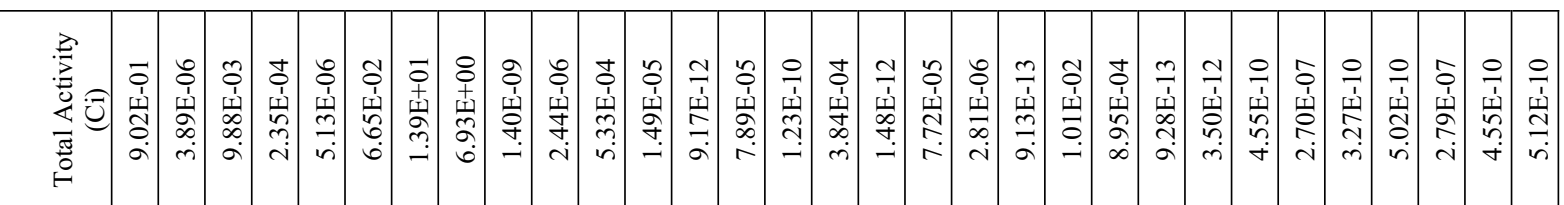

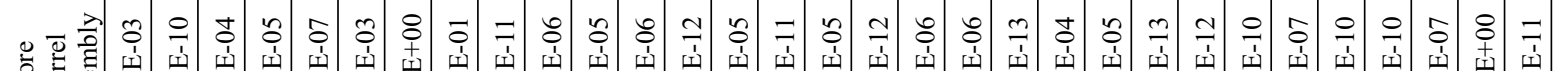

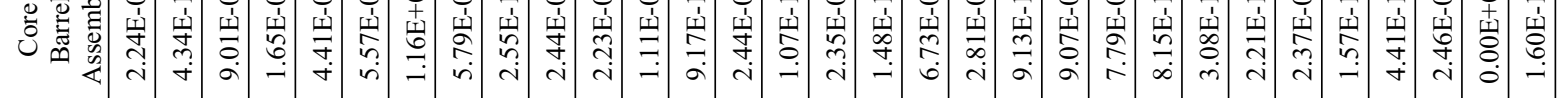

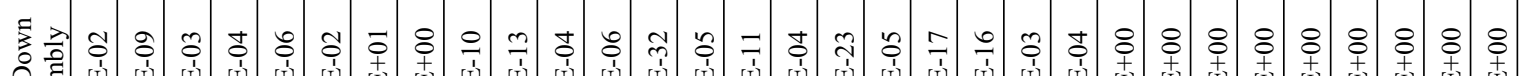

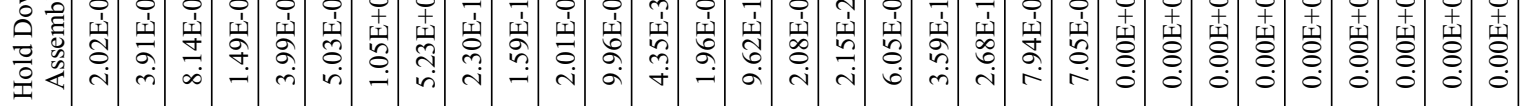

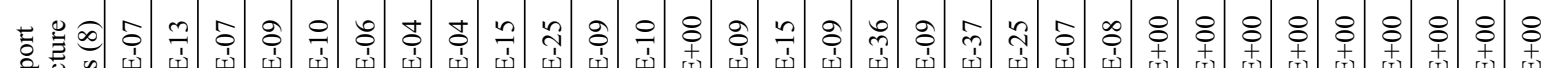

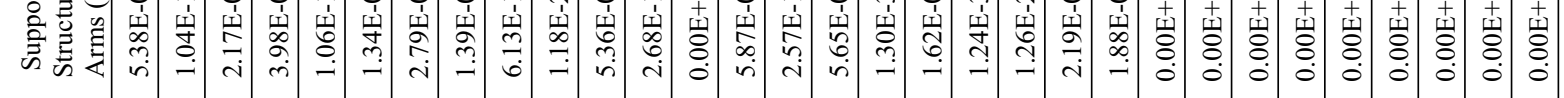

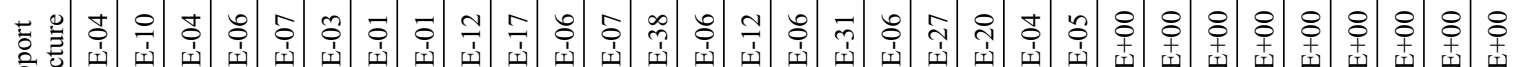

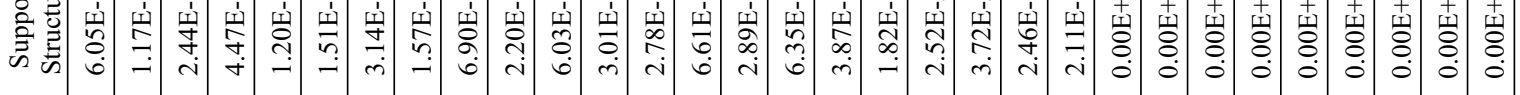

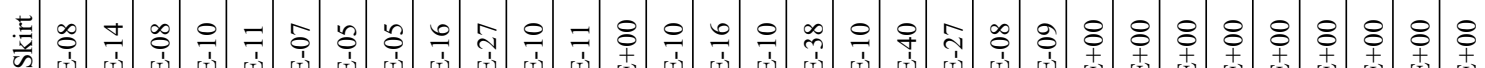

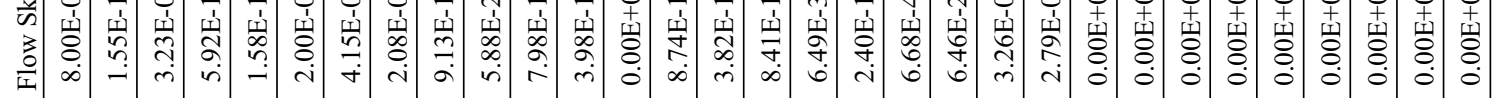

نे:

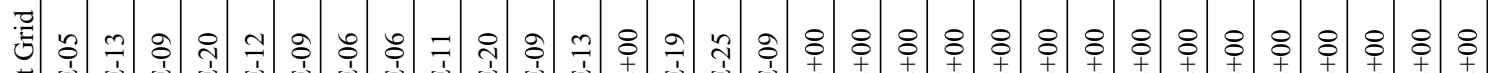

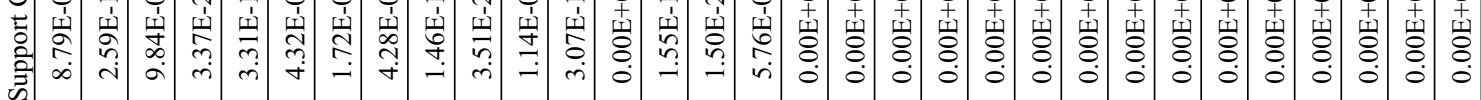

로

.

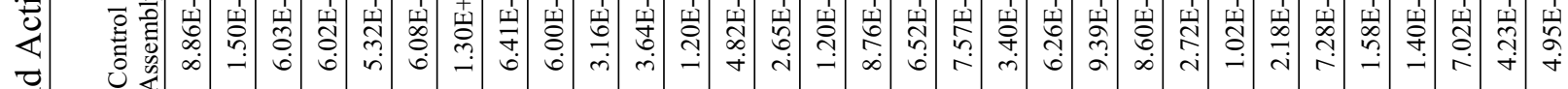

己ृ

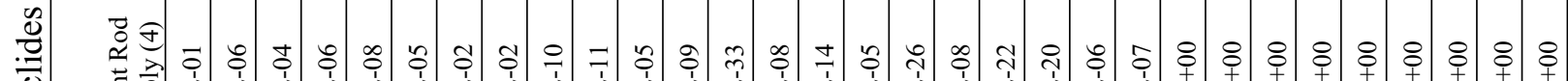

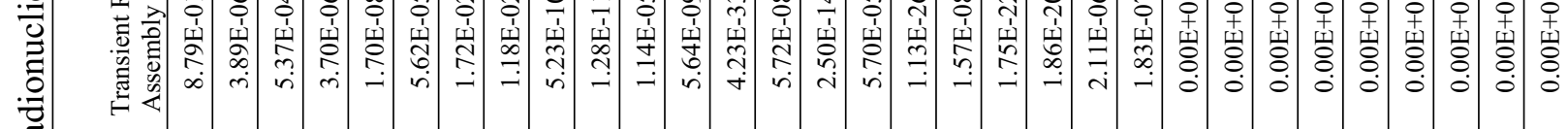

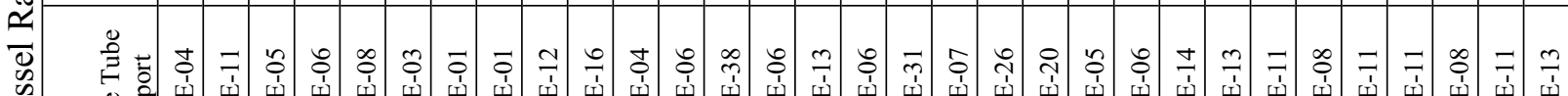

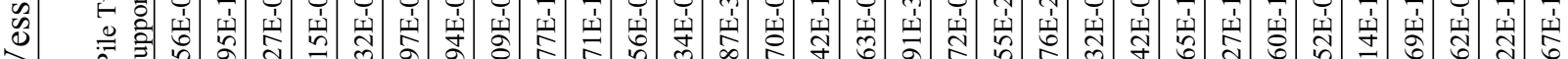

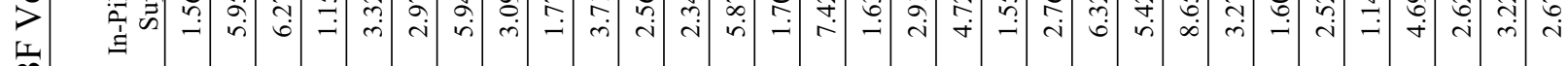

$\frac{1}{2}$

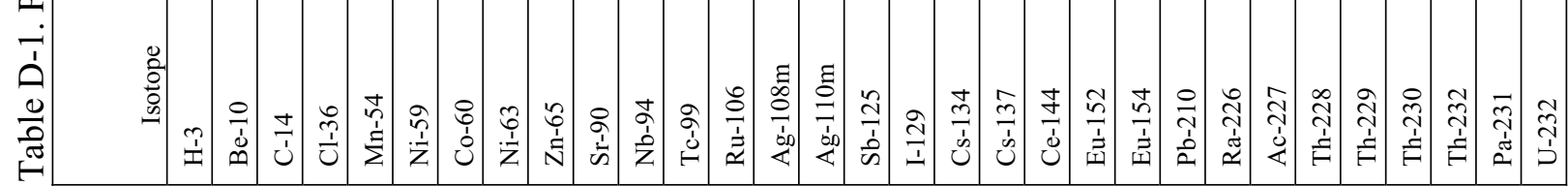




\begin{tabular}{|c|c|c|c|c|c|c|c|c|c|c|c|c|c|c|c|c|c|c|c|c|c|c|}
\hline 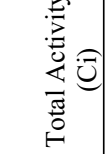 & 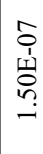 & $\begin{array}{l}0 \\
\text { ind } \\
\text { N }\end{array}$ & $\mid \begin{array}{c}0 \\
0 \\
0 \\
1 \\
\\
0 \\
\sim \\
\sim\end{array}$ & 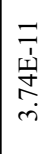 & 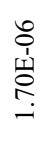 & 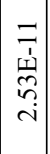 & \begin{tabular}{|l}
$\frac{9}{1}$ \\
离 \\
o \\
$\dot{+}$
\end{tabular} & 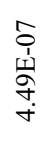 & 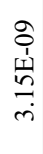 & 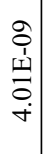 & 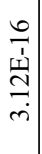 & 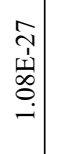 & 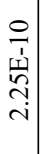 & 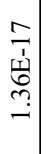 & 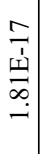 & 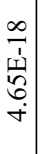 & 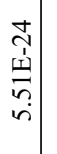 & 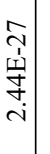 & 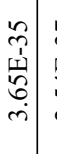 & | & 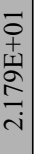 & \\
\hline 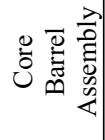 & 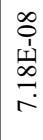 & 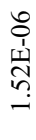 & \begin{tabular}{l}
$\infty$ \\
0 \\
1 \\
\multicolumn{1}{c}{} \\
0 \\
0 \\
0
\end{tabular} & 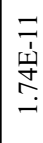 & 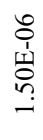 & $\begin{array}{c}= \\
7 \\
1 \\
\infty \\
\infty \\
-1 \\
-1\end{array}$ & 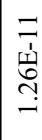 & 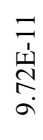 & 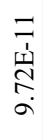 & $\begin{array}{l}7 \\
7 \\
1 \\
0 \\
0 \\
n \\
n\end{array}$ & 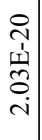 & $\begin{array}{c}\infty \\
0 \\
0 \\
\stackrel{1}{0} \\
\stackrel{1}{-}\end{array}$ & $\begin{array}{l}m \\
\frac{m}{1} \\
\frac{1}{ \pm} \\
\dot{m} \\
m\end{array}$ & 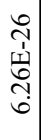 & $\begin{array}{l}8 \\
0 \\
+ \\
\text { 1 } \\
0 \\
0 \\
0\end{array}$ & 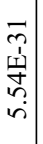 & $\begin{array}{l}0 \\
0 \\
+1 \\
\vdots \\
0 \\
0\end{array}$ & $\begin{array}{l}8 \\
\vdots \\
1 \\
\vdots \\
0 \\
0\end{array}$ & $\begin{array}{l}8 \\
\vdots \\
+1 \\
\vdots \\
0\end{array}$ & $\begin{array}{l}8 \\
\vdots \\
1 \\
\vdots \\
0 \\
0\end{array}$ & 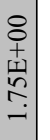 & \\
\hline 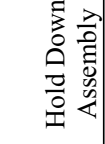 & $\begin{array}{l}8 \\
\vdots \\
+ \\
\text { t. } \\
0 \\
0\end{array}$ & $\begin{array}{l}8 \\
\vdots \\
+1 \\
\vdots \\
0 \\
0\end{array}$ & $\begin{array}{l}8 \\
\vdots \\
+1 \\
\text { 미 } \\
\vdots \\
0\end{array}$ & $\begin{array}{l}8 \\
0 \\
+ \\
\text { tan } \\
0 \\
0\end{array}$ & $\begin{array}{l}8 \\
0 \\
+1 \\
0 \\
0 \\
0\end{array}$ & \begin{tabular}{|l|}
8 \\
0 \\
+ \\
1 \\
19 \\
0 \\
0 \\
0
\end{tabular} & 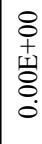 & $\begin{array}{l}8 \\
0 \\
+1 \\
\text { 10 } \\
0 \\
0\end{array}$ & $\begin{array}{l}8 \\
0 \\
+1 \\
0 \\
0 \\
0\end{array}$ & $\begin{array}{l}8 \\
+ \\
+1 \\
\vdots \\
0 \\
0\end{array}$ & $\begin{array}{l}8 \\
+ \\
+1 \\
0 \\
0 \\
0\end{array}$ & $\begin{array}{l}8 \\
0 \\
+ \\
\text { 19 } \\
0 \\
0\end{array}$ & $\begin{array}{l}8 \\
\vdots \\
+1 \\
\text { 19 } \\
0 \\
0\end{array}$ & $\begin{array}{l}8 \\
+ \\
+ \\
\vdots \\
\vdots \\
0\end{array}$ & $\begin{array}{l}8 \\
8 \\
+ \\
\text { 19 } \\
0 \\
0\end{array}$ & $\begin{array}{c}8 \\
\vdots \\
+ \\
\vdots \\
\vdots \\
0 \\
0\end{array}$ & $\begin{array}{l}8 \\
+ \\
+ \\
0 \\
0 \\
0\end{array}$ & $\begin{array}{l}8 \\
\vdots \\
+ \\
\text { 1. } \\
\vdots \\
\dot{0}\end{array}$ & $\begin{array}{l}8 \\
\vdots \\
+ \\
\vdots \\
\vdots \\
\vdots\end{array}$ & $\begin{array}{l}8 \\
8 \\
+ \\
\text { 11 } \\
0 \\
0 \\
0\end{array}$ & 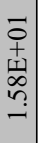 & \\
\hline 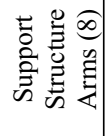 & $\begin{array}{l}8 \\
0 \\
+ \\
\text { 离 } \\
0 \\
0\end{array}$ & $\begin{array}{l}8 \\
\vdots \\
1 \\
\text { t1 } \\
8\end{array}$ & $\begin{array}{l}8 \\
+ \\
+1 \\
\vdots \\
0\end{array}$ & $\begin{array}{l}0 \\
0 \\
1 \\
\text { 音 } \\
0 \\
0\end{array}$ & $\begin{array}{l}8 \\
\vdots \\
+1 \\
\vdots \\
0 \\
0\end{array}$ & $\mid \begin{array}{c}8 \\
0 \\
+1 \\
0 \\
0 \\
0\end{array}$ & 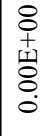 & $\begin{array}{l}8 \\
0 \\
+ \\
\text { 索 } \\
0 \\
0\end{array}$ & $\begin{array}{l}8 \\
0 \\
+4 \\
\vdots \\
0 \\
0\end{array}$ & $\begin{array}{l}8 \\
0 \\
+ \\
\vdots \\
0 \\
0\end{array}$ & $\begin{array}{l}8 \\
+ \\
+ \\
\vdots \\
0 \\
0\end{array}$ & \begin{tabular}{l|}
8 \\
0 \\
+ \\
⿶. \\
0 \\
0
\end{tabular} & $\begin{array}{l}8 \\
0 \\
+ \\
1 \\
8 \\
0 \\
0\end{array}$ & $\begin{array}{l}8 \\
+ \\
1 \\
0 \\
0 \\
0\end{array}$ & $\begin{array}{l}8 \\
0 \\
+1 \\
\text { 1 } \\
0 \\
0\end{array}$ & $\begin{array}{l}8 \\
0 \\
+ \\
\vdots \\
0 \\
0 \\
0\end{array}$ & $\begin{array}{l}8 \\
+ \\
+ \\
\vdots \\
0 \\
0\end{array}$ & $\begin{array}{l}8 \\
0 \\
+1 \\
\text { 19 } \\
0 \\
0\end{array}$ & $\begin{array}{l}8 \\
\vdots \\
+1 \\
\text { 1 } \\
\stackrel{0}{\circ}\end{array}$ & $\begin{array}{l}8 \\
\vdots \\
+ \\
\text { 11 } \\
8 \\
\vdots \\
0\end{array}$ & 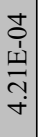 & \\
\hline 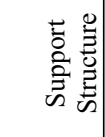 & $\begin{array}{l}0 \\
0 \\
+ \\
\text { ty } \\
0 \\
0\end{array}$ & $\begin{array}{l}8 \\
\vdots \\
1 \\
\text { I }\end{array}$ & $\begin{array}{l}8 \\
\vdots \\
+1 \\
\text { 19 } \\
0 \\
0\end{array}$ & 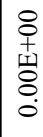 & $\begin{array}{l}8 \\
0 \\
+ \\
0 \\
0 \\
0\end{array}$ & \begin{tabular}{|c|} 
\\
0 \\
+ \\
1 \\
동 \\
0 \\
0 \\
0
\end{tabular} & 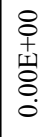 & $\begin{array}{l}8 \\
0 \\
+ \\
\text { t1 } \\
0 \\
0\end{array}$ & $\begin{array}{l}8 \\
0 \\
+1 \\
0 \\
0 \\
0\end{array}$ & $\begin{array}{l}8 \\
+ \\
+1 \\
0 \\
0 \\
0\end{array}$ & $\begin{array}{c}0 \\
\vdots \\
1 \\
\vdots \\
\vdots \\
0\end{array}$ & $\begin{array}{l}8 \\
\vdots \\
+0 \\
0 \\
0 \\
0\end{array}$ & \begin{tabular}{l|}
8 \\
+ \\
+1 \\
0 \\
0
\end{tabular} & $\begin{array}{l}8 \\
+ \\
1 \\
\vdots \\
0\end{array}$ & $\begin{array}{l}0 \\
+ \\
10 \\
0 \\
0\end{array}$ & $\begin{array}{c}8 \\
\vdots \\
1 \\
\vdots \\
0 \\
0\end{array}$ & $\begin{array}{c}\vdots \\
+ \\
+1 \\
\vdots \\
0\end{array}$ & \begin{tabular}{l|}
0 \\
+ \\
1 \\
$\vdots$ \\
0 \\
0
\end{tabular} & $\begin{array}{c}0 \\
\vdots \\
1 \\
\vdots \\
\vdots \\
.\end{array}$ & $\begin{array}{c}8 \\
\vdots \\
1 \\
\vdots \\
0 \\
0\end{array}$ & 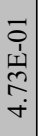 & \\
\hline 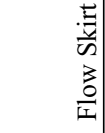 & $\begin{array}{l}8 \\
0 \\
+1 \\
0 \\
0 \\
0\end{array}$ & $\begin{array}{l}8 \\
\vdots \\
1 \\
\text { 잉 }\end{array}$ & $\begin{array}{l}8 \\
\vdots \\
0 \\
\vdots \\
0\end{array}$ & $\begin{array}{l}8 \\
\vdots \\
\text { 菖 } \\
0 \\
0\end{array}$ & $\begin{array}{l}8 \\
\vdots \\
+1 \\
\vdots \\
0\end{array}$ & $\mid \begin{array}{c}0 \\
+ \\
+ \\
\vdots \\
0 \\
0\end{array}$ & 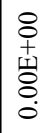 & $\begin{array}{l}8 \\
\vdots \\
+10 \\
0 \\
0 \\
0\end{array}$ & $\begin{array}{l}\stackrel{8}{+} \\
\text { 竦 } \\
0\end{array}$ & $\begin{array}{l}0 \\
\vdots \\
+9 \\
\vdots \\
0 \\
0\end{array}$ & $\begin{array}{c}0 \\
\vdots \\
+ \\
\vdots \\
\vdots \\
0\end{array}$ & $\begin{array}{l}0 \\
\vdots \\
+1 \\
\vdots \\
0 \\
0\end{array}$ & $\begin{array}{l}0 \\
\vdots \\
+0 \\
\vdots \\
0 \\
0\end{array}$ & $\begin{array}{c}0 \\
\vdots \\
\text { 1 } \\
\vdots \\
0 \\
0\end{array}$ & $\begin{array}{l}\stackrel{8}{+} \\
\text { 暲 } \\
0\end{array}$ & $\begin{array}{c}0 \\
\vdots \\
+1 \\
\vdots \\
0 \\
0\end{array}$ & $\begin{array}{l}\$ \\
\vdots \\
+1 \\
\vdots \\
\vdots \\
\vdots\end{array}$ & $\begin{array}{l}8 \\
+ \\
1 \\
0 \\
0 \\
0\end{array}$ & $\begin{array}{l}8 \\
\vdots \\
+ \\
\vdots \\
0 \\
0\end{array}$ & $\begin{array}{l}8 \\
+ \\
1 \\
0 \\
0 \\
0\end{array}$ & 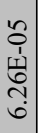 & \\
\hline 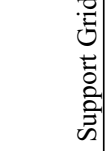 & $\begin{array}{l}8 \\
0 \\
+1 \\
\text { 音 } \\
0\end{array}$ & $\begin{array}{l}8 \\
0 \\
+ \\
\text { 甲1 } \\
8\end{array}$ & $\begin{array}{l}8 \\
0 \\
+1 \\
0 \\
0 \\
0\end{array}$ & $\begin{array}{l}8 \\
0 \\
1+1 \\
\text { 常 } \\
0 \\
0\end{array}$ & $\begin{array}{l}8 \\
0 \\
+10 \\
0 \\
0\end{array}$ & \begin{tabular}{|c|}
8 \\
0 \\
1 \\
1 \\
0 \\
8 \\
0 \\
0
\end{tabular} & 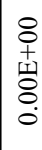 & $\begin{array}{l}8 \\
0 \\
+1 \\
0 \\
0 \\
0\end{array}$ & $\begin{array}{l}8 \\
0 \\
+1 \\
0 \\
0\end{array}$ & $\begin{array}{l}8 \\
\vdots \\
+1 \\
\vdots \\
\vdots \\
0\end{array}$ & $\begin{array}{l}8 \\
+ \\
+1 \\
\vdots \\
0\end{array}$ & $\begin{array}{l}0 \\
0 \\
+ \\
\text { 音 } \\
0\end{array}$ & $\begin{array}{l}8 \\
0 \\
+1 \\
0 \\
0 \\
0\end{array}$ & $\begin{array}{l}8 \\
+ \\
+1 \\
\vdots \\
0 \\
0\end{array}$ & $\begin{array}{l}8 \\
0 \\
+1 \\
0 \\
0 \\
0\end{array}$ & $\begin{array}{c}8 \\
+ \\
+1 \\
\vdots \\
0 \\
0\end{array}$ & $\begin{array}{l}8 \\
0 \\
+1 \\
\vdots \\
0 \\
0\end{array}$ & $\begin{array}{l}8 \\
0 \\
+1 \\
0 \\
0 \\
0\end{array}$ & $\begin{array}{l}8 \\
+ \\
+1 \\
\vdots \\
0\end{array}$ & 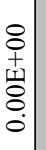 & $\begin{array}{l}c \\
0 \\
1 \\
a \\
\vdots \\
a\end{array}$ & \\
\hline 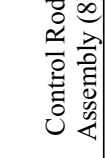 & 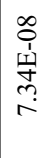 & 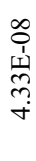 & 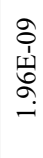 & $\begin{array}{l}7 \\
= \\
\infty \\
\infty \\
\infty \\
-1\end{array}$ & 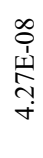 & 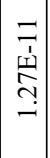 & 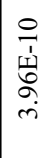 & 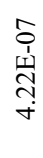 & 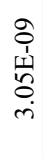 & 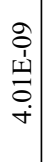 & $\begin{array}{l}0 \\
\frac{1}{1} \\
\underline{n} \\
\\
m\end{array}$ & \begin{tabular}{l}
$\hat{1}$ \\
$\overline{1}$ \\
\multicolumn{1}{c}{} \\
0 \\
- \\
-1
\end{tabular} & 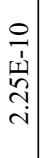 & 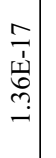 & 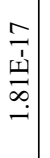 & 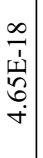 & 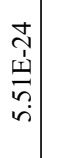 & 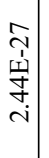 & 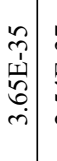 & 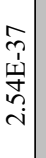 & 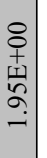 & \\
\hline 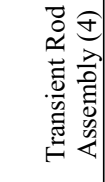 & $\begin{array}{l}8 \\
8 \\
+ \\
+1 \\
0 \\
0 \\
0\end{array}$ & $\stackrel{8}{+}$ & $\begin{array}{l}8 \\
0 \\
+ \\
\text { ⿶्10 } \\
0 \\
0\end{array}$ & $\begin{array}{l}8 \\
0 \\
1 \\
\text { tà } \\
0 \\
0\end{array}$ & $\begin{array}{l}8 \\
0 \\
+ \\
\text { 11 } \\
0 \\
0\end{array}$ & $\left|\begin{array}{c}8 \\
0 \\
+ \\
0 \\
0 \\
0 \\
0\end{array}\right|$ & 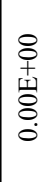 & $\begin{array}{l}8 \\
0 \\
+1 \\
\text { 11 } \\
0 \\
0\end{array}$ & $\begin{array}{l}8 \\
0 \\
+1 \\
0 \\
0 \\
0\end{array}$ & $\begin{array}{l}8 \\
+ \\
+1 \\
\vdots \\
0 \\
0\end{array}$ & $\begin{array}{c}8 \\
+ \\
1 \\
\vdots \\
0 \\
0\end{array}$ & $\begin{array}{l}0 \\
0 \\
+ \\
\text { ज1 } \\
0 \\
0\end{array}$ & $\begin{array}{l}8 \\
0 \\
+1 \\
0 \\
0 \\
0\end{array}$ & $\begin{array}{c}8 \\
+ \\
1 \\
\vdots \\
0 \\
0\end{array}$ & $\begin{array}{l}8 \\
+ \\
\text { 19. } \\
\text { ठ. } \\
0\end{array}$ & $\begin{array}{c}8 \\
+ \\
+1 \\
\vdots \\
0 \\
0\end{array}$ & $\begin{array}{l}8 \\
+ \\
1 \\
\vdots \\
0 \\
0\end{array}$ & $\begin{array}{c}8 \\
0 \\
+ \\
\text { 19 } \\
0 \\
0\end{array}$ & $\begin{array}{l}8 \\
+ \\
+ \\
\text { 19. } \\
0 \\
0\end{array}$ & 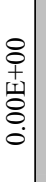 & 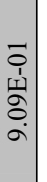 & 。 \\
\hline 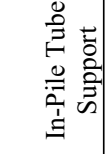 & oे & 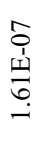 & 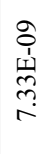 & 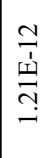 & 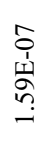 & $\left|\begin{array}{c}m \\
1 \\
1 \\
0 \\
0 \\
\infty \\
\infty\end{array}\right|$ & 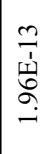 & 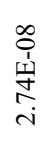 & 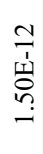 & 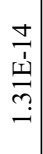 & 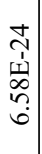 & 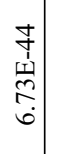 & 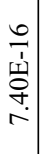 & 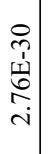 & $\begin{array}{l}8 \\
+ \\
\text { 19. } \\
0 \\
0 \\
0\end{array}$ & 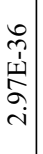 & \begin{tabular}{l|}
8 \\
+ \\
+1 \\
$\vdots$ \\
$\vdots$ \\
$\vdots$
\end{tabular} & $\begin{array}{l}0 \\
0 \\
+ \\
\mathbf{1} \\
0 \\
0\end{array}$ & $\begin{array}{l}8 \\
\vdots \\
1 \\
\vdots \\
\vdots \\
0\end{array}$ & 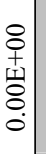 & 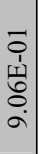 & 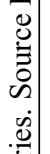 \\
\hline & $\hat{3}$ & & $\hat{c}$ & స్ & c) & 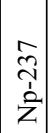 & ָָ & ત્సે & 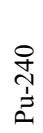 & $\underset{\mathfrak{T}}{\vec{T}}$ & 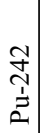 & 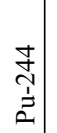 & $\begin{array}{l}\stackrel{1}{1} \\
\stackrel{\Xi}{\Xi}\end{array}$ & 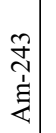 & 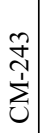 & 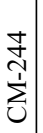 & 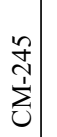 & 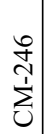 & 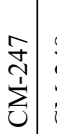 & $\stackrel{4}{4}$ & : & $\overline{7}$ \\
\hline
\end{tabular}

